Thaís Fernanda da Silva Machado

Estudo comparativo da localização do seio venoso sagital dorsal no crânio de cães braquicefálicos e mesaticefálicos para craniotomia transfrontal 
Thaís Fernanda da Silva Machado

\section{Estudo comparativo da localização do seio venoso sagital dorsal no crânio de cães braquicefálicos e mesaticefálicos para craniotomia transfrontal}

Dissertação apresentada para o Programa de Pós Graduação em Anatomia dos Animais Domésticos e Silvestres da Faculdade de Medicina Veterinária e Zootecnia da Universidade de São Paulo para obtenção do título de Mestre em Ciências

Departamento:

Cirurgia

Área de Concentração:

Anatomia dos Animais Domésticos e Silvestres

Orientador:

Prof. Dr. Cássio Ricardo Auada Ferrigno

São Paulo

2006 
Autorizo a reprodução parcial ou total desta obra, para fins acadêmicos, desde que citada a fonte.

DADOS INTERNACIONAIS DE CATALOGAÇÃO-NA-PUBLICAÇÃO

(Biblioteca Virginie Buff D’Ápice da Faculdade de Medicina Veterinária e Zootecnia da Universidade de São Paulo)

T.1679 Machado, Thaís Fernanda da Silva

FMVZ Estudo comparativo da localização do seio venoso sagital dorsal no crânio de cães braquicefálicos e mesaticefálicos para craniotomia transfrontal / Thaís Fernanda da Silva Machado. - São Paulo: T. F. S Machado, 2006.

$101 \mathrm{f}$ : : il.

Dissertação (mestrado) - Universidade de São Paulo. Faculdade de Medicina Veterinária e Zootecnia. Departamento de Cirurgia, 2006.

Programa de Pós-graduação: Anatomia dos Animais Domésticos e Silvestres.

Área de concentração: Anatomia dos Animais Domésticos e Silvestres.

Orientador: Prof. Dr. Cássio Ricardo Auada Ferrigno.

1. Cérebro. 2. Craniotomia. 3. Seio venoso. 4. Braquicefálico. I. Título. 


\section{UNIVERSIDADE DE SÃO PAULO Faculdade de Medicina Veterinaria e Zootecnia Assistência Acadêmica \\ $P A R E C E R$}

Interessado: Thaís Fernanda da Silva Machado

Assunto: Protocolo de experimentação adotado em experimento animal.

A Comissão de Bioética da Faculdade de Medicina Veterinária e Zootecnia da Universidade de São Paulo, após analisar o projeto sob o número 742/2005, intitulado: “Estudo comparativo da localização do seio venoso sagital dorsal no crânio de cães braquicefálicos e mesaticefálicos nas abordagens rostrotentorial, transfrontal e caudotentorial", utilizando 20 cadáveres de cães, sob responsabilidade do Prof. Dr. Cássio Ricardo Auadá Ferrigno, constatou que o mesmo foi realizado de acordo com os princípios de bioética, adotados por esta Comissão.

São Paulo, 23 de agosto de 2005

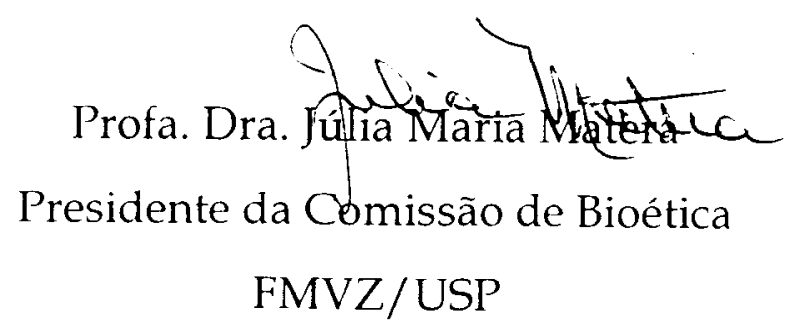




\section{FOLHA DE AVALIAÇÃO}

Nome do autor: MACHADO, Thaís Fernanda da Silva

Título: Estudo comparativo da localização do seio venoso sagital dorsal no crânio de cães braquicefálicos e mesaticefálicos para craniotomia transfrontal

Dissertação apresentada para o Programa de Pós Graduação em Anatomia dos Animais Domésticos e Silvestres da Faculdade de Medicina Veterinária e Zootecnia da Universidade de São Paulo para obtenção do título de Mestre em Ciências

Data:

\section{Banca Examinadora}

Prof. Dr. Instituição:

Assinatura Julgamento:

Prof. Dr. Instituição:

Assinatura Julgamento:

Prof. Dr. Instituição:

Assinatura Julgamento: 
"A melhor recompensa que a vida oferece é a oportunidade de trabalhar duro em algo que valha a pena"(Theodore Roosevelt)

Aos meus pais, Carlos e Wilma pelo amor, carinho, ajuda e dedicação desde 26 de outubro de 1979.

Ao meu irmão André, pelo exemplo e inspiração. 
"Nossas cabeças são redondas para que os pensamentos possam mudar de direção." (Francis Piacaba, pintor e escritor francês, 1879-1953)

Ao Fábio, que compreendeu a importância desse momento com muito amor e paciência, sempre com uma palavra otimista 


\section{AGRADECIMENTOS}

Ao Prof. Dr. Cássio Ricardo Auada Ferrigno pela orientação deste trabalho, sempre com muita disposição, decorrente de anos de ensinamentos e pela amizade, por proporcionar o desenvolvimento dessa etapa na Universidade de São Paulo;

À Professora Dra Ana Carolina Brandão de Campos Fonseca Pinto pela disposição e paciência, sempre que solicitada ainda que no seu período de licença maternidade;

Ao Professor Dr Pedro Primo Bombonato pelas sugestões e críticas oportunas para a realização deste trabalho;

À Professora Dra. Maria Angélica Miglino, pela oportunidade concedida no departamento de Anatomia dos Animais Domésticos e Silvestres;

Ao Conselho Nacional de Desenvolvimento Científico e Tecnológico (CNPq), pela concessão de bolsa de mestrado;

Aos amigos "conselheiros" Alexandre Schmaedecke e Robson Fortes Giglio pelas conversas e ajuda sempre que preciso;

Aos amigos Daniel e Evelise Baccarin pela amizade, incentivo profissional e confiança, a mim dedicados;

À toda equipe do Koala Animal Hospital: médicos veterinários Luis Leon Cyon, Lourenço C.Cotes, Valéria de Carvalho, Renata Setti; e enfermeiros: Rogério, Juca, Fábio e Fernando;

À Tatiana Bragante, Isaac Albuquerque, Hildebrando Benedicto, Fernanda Agreste, Haley de Carvalho pela amizade e ajuda na execução do trabalho;

Ao colega veterinário e da pós-graduação Ryan e equipe do Centro Veterinário Piera;

Às mestrandas Iara e Luciana pela grande ajuda com os exames tomográficos;

Aos colegas da pós-graduação, Eduardo, Thalita, Rosa, Rita, Rosemary, Priscila, Érika, Mamão, André, Juliana, Renata, Marco Antônio; pela convivência durante esse período, companheiros de disciplinas, projetos e plantões; 
Ao meu pai, Carlos Alberto, pela confecção dos desenhos, sempre perfeccionista e brilhante;

Ao amigo Carlos Amadori, pela ajuda na análise estatística e por participar dessa etapa da minha carreira;

À amiga e cunhada Graziela Camargo e equipe, pelo auxílio com as imagens e desenhos;

À todos os funcionários do Setor de Anatomia dos Animais Domésticos e Silvestres, Índio, Ronaldo, Diogo, Cauê, Jackeline e Maicon

Aos funcionários do Setor de Diagnóstico por Imagem, Hugo, Reginaldo, Benjamin, Kátia e a médica veterinária Silvana M. Unruh pela grande ajuda na viabilização deste experimento.

Aos colegas do Laboratório de Ortopedia e Traumatologia Comparada da FMVZ-USP, Silmara, Leonardo, Leandro, Márcio.

A todos amigos e amigas que contribuíram direta e indiretamente para a realização desse trabalho. 


\section{RESUMO}

MACHADO, T. F. S. Estudo comparativo da localização do seio venoso sagital dorsal no crânio de cães braquicefálicos e mesaticefálicos para craniotomia transfrontal. [Comparative evaluation of the dorsal sagittal sinus localization in the braquicephaly and mesaticephaly dogs to transfrontal craniotomy.] 2006. 85 f. Dissertação (Mestrado em Ciências) - Faculdade de Medicina Veterinária e Zootecnia, Universidade de São Paulo, São Paulo, 2006.

Técnicas cirúrgicas para realização de craniotomias são descritas na literatura há mais de cinqüenta anos. Contudo, a sua realização ainda é limitada, muitas vezes pela ausência de diagnóstico conclusivo. Com o advento de métodos não invasivos como a tomografia computadorizada, a especificidade quanto ao tipo e localização da lesão tornou-se possível. As principais abordagens cranianas são as técnicas de craniotomia transfrontal que promovem acesso ao cérebro. Os principais pontos de referência para a realização da técnica são os seios venosos da dura mater. Este estudo visou analisar o acesso cirúrgico em relação ao seio venoso sagital dorsal, bem como compará-lo nos diferentes tipos de crânio: braquicefálico e mesaticefálico. Foram utilizados 16 crânios provenientes de 8 cães da raça boxer, 5 cães sem raça definida, 1 rotweiller, 1 labrador e 1 pinscher. $O$ trajeto do seio venoso sagital superior foi estudado pelo método de injeção de solução de látex com pigmento colorido e sulfato de bário. A relação do SVSD foi estudada através de análise das imagens obtidas pela tomografia computadorizada. Os crânios braquicefálicos apresentaram índice cefálico médio igual à 91,24 e índice crânio fácil igual à 2,89; enquanto nos crânio mesaticefálicos obtivemos os valores médios de 79,77 e 1,92 para os índices cefálico e crânio facial respectivamente. O trajeto do seio venoso sagital dorsal foi delimitado, tendo início na porção média do arco zigomático e término ao nível do osso occipital nos dois grupos de crânios. Em relação às mensurações do seio venoso relativas à calota craniana obtivemos os valores médios da área $=$ 7,35+-2,51; D1 = 6,65+-2,27; D2 = 16,17+-4,08; D3 = 15,75-+5,09; D4 = 18,33+-5,25 e D5 = 18,04+-5,87 no grupo mesaticefálico e os valores médios da área $=10,18+-4,69 ; \mathrm{D} 1=$ 
$11,84+-2,35 ; \mathrm{D} 2=19,57+-2,61 ; \mathrm{D} 3=17,88+-2,31 ; \mathrm{D} 4=25,32+-5,68$ e D5 $=24,84=-4,40$ no grupo braquicefálico. Os valores referentes á área, D4 e D5 apresentaram diferença estatística $(\mathrm{P}<0,05)$, que denota diferença no formato da calota craniana entre os dois grupos, assim consequentemente diferença na medida citada como margem de segurança para a realização da abordagem cirúrgica do cérebro.

Palavras-chave: Cérebro. Craniotomia. Seio venoso. Braquicefálico. 


\begin{abstract}
MACHADO, T. F. S. Comparative evaluation of the dorsal sagittal sinus localization on braquicephaly and mesaticephaly skulls to transfrontal craniotomy. [Estudo comparativo da localização do seio venoso sagital dorsal no crânio de cães braquicefálicos e mesaticefálicos para craniotomia transfrontal] 2006. 85 f. Dissertação (Mestrado em Ciências) - Faculdade de Medicina Veterinária e Zootecnia, Universidade de São Paulo, São Paulo, 2006.
\end{abstract}

The surgical approaches for craniotomy are describe since the fifties. However, this realization is limited, many times for the absence conclusive diagnosis. The non invasive methods like computed tomography, the lesion locatization and type are easily made. The most important surgical approach is transfrontal craniotomy which promoves brain access. The principal landmarks to the surgery are the dura mater venous sinus. The objetive of this study was to analise the surgical access relation to the dorsal sagittal sinus and to compare with the different skull type: mesaticephalic and braquicephalic. Sixteen skulls from 8 Boxer dogs, 5 Mongrel dogs, 1 Rottweiler, 1 Labrador and 1 Pinscher. The sinus path was studied by solution of bario and látex whith coloured pigment injection. The dorsal sagittal sinus relation was studied by CT image analysis. The braquicephalic skulls showed cephalic index $=91,24$ and cranio facial index $=2,89$, and the mesaticephalic skulls presents 79,77 and 1,92 for cephalic and crânio facial index. The dorsal sagittal sinus path was delimited, and the medium of the zigomatic arc is this begging and the occipital bone the final, in both skull types. The venous sinus mensurations interface to the skull are: area $=7,35+/-2,51 ; \mathrm{D} 1=6,65+-2,27$; 2 $=16,17+-4,08 ; \mathrm{D} 3=15,75-+5,09 ; \mathrm{D} 4=18,33+-5,25$ e $\mathrm{D} 5=18,04+-5,87$ in mesaticephalic dogs and the medium mensurations da area $=10,18+-4,69 ; \mathrm{D} 1=11,84+-2,35 ; \mathrm{D} 2=19,57+-$ 2,$61 ; \mathrm{D} 3=17,88+-2,31 ; \mathrm{D} 4=25,32+-5,68$ e D5 $=24,84=-4,40$ in braquicephalic group. 
The área, D4 and D5 mensurations presents statistic difference $(\mathrm{P}<0,05)$, which show the skull form difference betwen the two groups, and the edge for the surgical approach to the brain.

Key words: Brain. Craniotomy. Venous sinus. Braquicephalic. 


\section{LISTA DE FIGURAS}

Figura 1 - Crânio braquicefálico (esquerda) e mesaticefálico (direita) - São Paulo - 2006 (Apêndice A)

Figura 2 - Seio Venoso Sagital Dorsal (SVSD) - São Paulo - 2006 (Apêndice A)

Figura 3 - Esquema dos seios venosos da dura máter - São Paulo - 2006 (Apêndice B)

Figura 4 - Representação dos seios venosos da dura mater - São Paulo - 2006 (Apêndice C).

Figura 5 - Mensuração comprimento crânio - São Paulo - 2006 (Apêndice D)

Figura 6 - Mensuração comprimento face - São Paulo - 2006 (Apêndice D)

Figura 7 - Mensuração largura do crânio - São Paulo - 2006 (Apêndice D).

Figura 8 - Radiografia contrastada crânio braquicefálico, incidência latero lateral esquerda (a) e dorso

$\begin{array}{lllllll}\text { ventral (b) } & - & \text { São } & \text { Paulo } & - & 2006 & \text { (Apêndice }\end{array}$ E).

Figura 9 - Radiografia contrastada crânio mesaticefálico, incidência latero lateral esquerda (a) e dorso ventral (b) - $\quad$ São Paulo - 2006 (Apêndice F).

Figura 10 - Imagem da tomografia computadorizada, crânio mesaticefálico (M6), radiografia digital
(a)
corte $\quad 12$
(b)
São
Paulo - 2006
(Apêndice

G)...

Figura 11 - Imagem da tomografia computadorizada, crânio braquicefálico (B6), radiografia digital (a) e corte 4 (b) - São Paulo - 2006 (Apêndice $\mathrm{H})$.

Figura 12 - Ferramenta Geometric calibration, janela do programa KS 4003.0 - São Paulo - 2006 (Apêndice I).

Figura 13 - Delimitação da área $\left(\mathrm{mm}^{2}\right)$, janela do programa KS 4003.0 - São Paulo - 2006 (Apêndice J).

Figura 14 - Delimitação das medidas do ponto médio do SVSD ao ápice da calota craniana (D1) e às extremidades laterais da calota craniana (D2 e D3), em mm, janela do programa KS 400 3.0-SãoPaulo-206(ApêndiceK). 
Figura 15 - Delimitação das medidas do contorno da calota craniana(D4 e D5)à intersecção com as medidasD2 eD3,em mm, janela do programaKS4003.0-SãoPaulo-2006(Apêndice L) 101

Figura 16 - Representação da margem de segurança para a incisão nos crânios braquicefálicos e mesaticefálicos, amarelo $=0,5 \mathrm{~cm}$; vermelho $=1,0 \mathrm{~cm}$ - São Paulo -2006 (Apêndice $\mathrm{M}$

Figura 17 -

Gráfico do comprimento do crânio $(\mathrm{mm})$ dos animais braquicefálicos e mesaticefálicos São Paulo - 2006.

Figura 18 - Gráfico da largura do crânio $(\mathrm{mm})$ dos animais braquicefálicos e mesaticefálicos - São Paulo - 2006.

Figura 19 - Gráfico do comprimento da face $(\mathrm{mm})$ dos animais braquicefálicos e mesaticefálicos - São Paulo - 2006

Figura 20 - Gráfico do IC dos animais braquicefálicos e mesaticefálicos - São Paulo - 2006.

Figura 21 - Gráfico do ICF dos animais braquicefálicos e mesaticefálicos - São Paulo - 2006.

Figura 22 - Gráfico da representação das medidas D1 (perpendicular), D2 (horizontal esquerda), D3 (horizontal direita), D4 (contorno calota lado esquerdo) e D5 (contorno calota lado direito), dos animais mesaticefálicos, em mm - São Paulo - 2006.

Figura 23 - Gráfico da representação das medidas D1 (perpendicular), D2 (horizontal esquerda), D3 (horizontal direita), D4 (contorno calota lado esquerdo) e D5 (contorno calota lado direito), dos animais mesaticefálicos, em mm - São Paulo - 2006.

Figura 24 - Gráfico dos valores da área $\left(\mathrm{mm}^{2}\right)$ : média, desvio padrão (dp), valor mínimo, mediana e valor máximo para os animais braquicefálicos e mesaticefálicos - São Paulo - 2006

Figura 25 - Gráfico dos valores D1 (mm): média, desvio padrão (dp), valor mínimo, mediana e valor máximo para os animais braquicefálicos e mesaticefálicos - São Paulo - 2006.

Figura 26 - Gráfico dos valores D2 (mm): média, desvio padrão (dp), valor mínimo, mediana e valor máximo para os animais braquicefálicos e mesaticefálicos - São Paulo - 2006.

Figura 27 - Gráfico dos valores D3 $(\mathrm{mm})$ : média, desvio padrão (dp), valor mínimo, mediana e valor máximo para os animais braquicefálicos e mesaticefálicos - São Paulo - 2006.

Figura 28 - Gráfico dos valores D4 (mm): média, desvio padrão (dp), valor mínimo, mediana e valor máximo para os animais braquicefálicos e mesaticefálicos - São Paulo - 2006.

Figura 29 - Gráfico dos valores D5 (mm): média, desvio padrão (dp), valor mínimo, mediana e valor máximo para os animais braquicefálicos e mesaticefálicos - São Paulo - 2006. 


\section{LISTA DE ABREVIATURAS E SIGLAS}

$\begin{array}{ll}\text { ATM } & \text { Articulação Têmporo mandibular } \\ \text { B1 } & \text { Crânio braquicefálico 1 } \\ \text { B2 } & \text { Crânio braquicefálico 2 } \\ \text { B3 } & \text { Crânio braquicefálico 3 } \\ \text { B4 } & \text { Crânio braquicefálico 4 } \\ \text { B5 } & \text { Crânio braquicefálico 5 } \\ \text { B6 } & \text { Crânio braquicefálico 6 } \\ \text { B7 } & \text { Crânio braquicefálico } 7 \\ \text { B8 } & \text { Crânio braquicefálico 8 } \\ \text { DP } & \text { Desvio Padrão } \\ \text { g } & \text { Gramas } \\ \text { IC } & \text { Índice Cefálico } \\ \text { ICF } & \text { Índice Crânio Cefálico } \\ \text { M } & \text { Média } \\ \text { M1 } & \text { Crânio mesaticefálico 1 } \\ \text { M2 } & \text { Crânio mesaticefálico 2 } \\ \text { M3 } & \text { Crânio mesaticefálico 3 } \\ \text { M4 } & \text { Crânio mesaticefálico 4 } \\ \text { M5 } & \text { Crânio mesaticefálico 5 } \\ \text { M6 } & \text { Crânio mesaticefálico 6 } \\ \text { M7 } & \text { Crânio mesaticefálico 7 } \\ \text { M8 } & \text { Crânio mesaticefálico 8 } \\ \text { mm } & \text { Milímetros } \\ \text { mm Hg } & \text { Milímetros de mercúrio } \\ \text { mm } 2 & \text { Milímetros quadrados } \\ \text { PAM } & \text { Pressão Arterial Média } \\ \text { PIC } & \text { Pressão Intracraniana } \\ \text { SNC } & \text { Sistema Nervoso Central } \\ \text { SRD } & \text { Sem raça definida } \\ \text { SVSD } & \text { Seio Venoso Sagital Dorsal }\end{array}$




\section{LISTA DE TABELAS}

Tabela 1 - Medidas em mm do comprimento, largura e índice cefálico dos mesaticefálicos - São Paulo - 2006.

Tabela 2 - Medidas em mm do comprimento, largura e índice cefálico dos braquicefálicos - São Paulo - 2006.

Tabela 3 - Medidas em mm do comprimento da face e do crânio e índice crânio facial (ICF) dos mesaticefálicos - São Paulo 2006.

Tabela 4 - Medidas em mm do comprimento da face e do crânio e índice crânio facial (ICF) dos braquicefálicos - São Paulo - 2006

Tabela 5 - Medidas da área $\left(\mathrm{mm}^{2}\right)$ e distâncias relativas do SVSD $(\mathrm{mm})$ à calota craniana do crânio B1 - São Paulo - 2006.

Tabela 6 - Medidas da área $\left(\mathrm{mm}^{2}\right)$ e distâncias relativas do SVSD $(\mathrm{mm})$ à calota craniana do crânio B2 - São Paulo - 2006.

Tabela 7 - Medidas da área $\left(\mathrm{mm}^{2}\right)$ e distâncias relativas do SVSD (mm) à calota craniana do crânio B3 - São Paulo - 2006.

Tabela 8 - Medidas da área $\left(\mathrm{mm}^{2}\right)$ e distâncias relativas do SVSD (mm) à calota craniana do crânio B4 - São Paulo - 2006.

Tabela 9 - Medidas da área $\left(\mathrm{mm}^{2}\right)$ e distâncias relativas do SVSD (mm) à calota craniana do crânio B5 - São Paulo - 2006.

Tabela 10 - Medidas da área $\left(\mathrm{mm}^{2}\right)$ e distâncias relativas do SVSD (mm) à calota craniana do crânio B6 - São Paulo - 2006.

Tabela 11 - Medidas da área $\left(\mathrm{mm}^{2}\right)$ e distâncias relativas do SVSD (mm) à calota craniana do crânio B7 - São Paulo - 2006.

Tabela 12 - Medidas da área $\left(\mathrm{mm}^{2}\right)$ e distâncias relativas do SVSD (mm) à calota craniana do crânio B8 - São Paulo - 2006.

Tabela 13 - Medidas da área $\left(\mathrm{mm}^{2}\right)$ e distâncias relativas do SVSD (mm) à calota craniana do crânio M1 - São Paulo - 2006.

Tabela 14 - Medidas da área $\left(\mathrm{mm}^{2}\right)$ e distâncias relativas do SVSD (mm) à calota craniana do crânio M2 - São Paulo - 2006.

Tabela 15 - Medidas da área $\left(\mathrm{mm}^{2}\right)$ e distâncias relativas do SVSD (mm) à calota craniana do crânio M3 - São Paulo - 2006. 
Tabela 16 - Medidas da área $\left(\mathrm{mm}^{2}\right)$ e distâncias relativas do SVSD (mm) à calota craniana do crânio M4 - São Paulo - 2006.

Tabela 17 - Medidas da área $\left(\mathrm{mm}^{2}\right)$ e distâncias relativas do SVSD (mm) à calota craniana do crânio M5 - São Paulo - 2006.

Tabela 18 - Medidas da área $\left(\mathrm{mm}^{2}\right)$ e distâncias relativas do SVSD (mm) à calota craniana do crânio M6 - São Paulo - 2006.

Tabela 19 - Medidas da área $\left(\mathrm{mm}^{2}\right)$ e distâncias relativas do SVSD (mm) à calota craniana do crânio M7 - São Paulo - 2006.

Tabela 20 - Medidas da área $\left(\mathrm{mm}^{2}\right)$ e distâncias relativas do SVSD (mm) à calota craniana do crânio M8 - São Paulo - 2006.

Tabela 21 - Média da área $\left(\mathrm{mm}^{2}\right)$ do SVSD dos crânios braquicefálicos e mesaticefálicos - São Paulo - 2006

Tabela 22 - Média da distância (mm) entre o ponto médio do SVSD e o ápice da calota craniana (D1) dos crânios braquicefálicos e mesaticefálicos - São Paulo - 2006.

Tabela 23 - Média da distância $(\mathrm{mm})$ entre o ponto médio do SVSD e a extremidade lateral direita da calota craniana (D2) dos crânios braquicefálicos e mesaticefálicos - São Paulo - 2006

Tabela 24 - Média da distância $(\mathrm{mm})$ entre o ponto médio do SVSD e a extremidade lateral esquerda da calota craniana (D3) dos crânios braquicefálicos e mesaticefálicos - São Paulo - 2006

Tabela 25 - Média da distância $(\mathrm{mm})$ do contorno da calota craniana até a intersecção de D2 (D4)dos crânios braquicefálicos e mesaticefálicos - São Paulo - 2006...

Tabela 26 - Média da distância ( $\mathrm{mm}$ ) do contorno da calota craniana até a intersecção de D3 (D5)dos crânios braquicefálicos e mesaticefálicos - São Paulo - 2006. 


\section{SUMÁRIO}

1 INTRODUÇÃO

2 REVISÃO DE LITERATURA .................................................................... 21

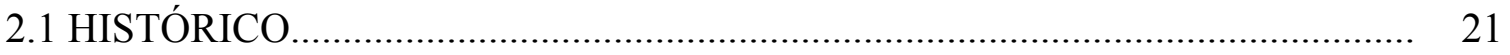

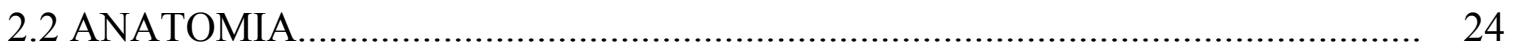

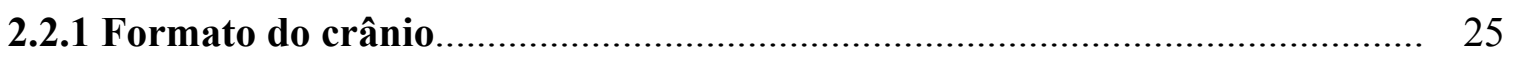

2.2.2 Vascularização

2.3 DIAGNÓSTICO POR IMAGEM........................................................................ 33

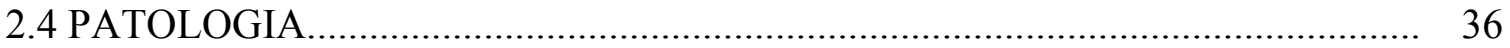

2.5 TÉCNICAS CIRÚRGICAS......................................................................... 38

3 MATERIAL E MÉTODO_........................................................................... 45

3.1 DELINEAMENTO EXPERIMENTAL .............................................................. 45

3.1.1 Perfusão dos vasos sanguíneos...................................................................... 45

3.1.2 Análise macroscópica.................................................................................. 46

3.1.3 Imagens radiográficas........................................................................... 47

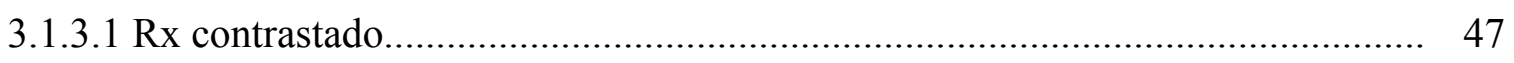

3.1.3.2 Tomografia computadorizada........................................................................... $\quad 47$

3.1.4 Análise das imagens................................................................................... 48

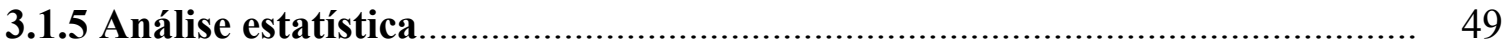

4 RESULTADOS

4.1 ANÁLISE MACROSCÓPICA........................................................................... 50

4.2 ANÁLISE DAS IMAGENS............................................................................ 55

5 DISCUSSÃO

6 CONCLUSÕES 


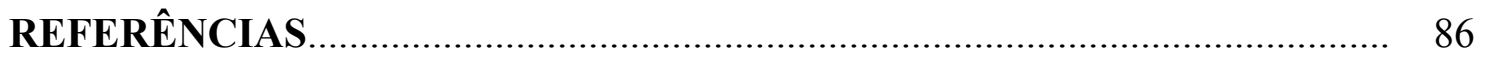

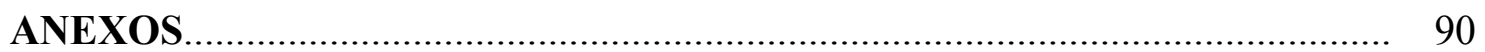




\section{INTRODUÇÃO}

Os seios venosos são corredores venosos com paredes finas e rígidas, localizados no interior da dura mater ou dos canais ósseos do crânio. Possuem importância clinica, pois recebem as veias que drenam o encéfalo e os ossos do crânio e carreiam sangue venoso para os pares de veias maxilares, jugulares internas e para os plexos venosos vertebrais (EVANS, 1994).

Lesões na rede venosa cerebral podem causar déficits severos como hemiplegia, hemorragias, coma e óbito do paciente. As lesões podem, ser causadas por trombose, inflamação, neoplasia ou trauma. As veias cerebrais que apresentam maiores dificuldades para os acessos cirúrgicos estão localizadas na região do lobo temporal e ao longo da porção central do seio sagital dorsal. (RHOTON, 2002).

O crânio dos cães possui formato característico relacionado à raça. Ainda assim, existem diferenças individuais quanto ao tamanho e forma. A terminologia do formato do crânio em mesaticefálico, dolicocefálico e braquicefálico foi adotada pela medicina veterinária em 1891, baseada na classificação do crânio humano de Skelettlehre et al, 1886.

De acordo com o formato do crânio, podem estar presentes diferenças anatômicas, como formato, peso e tamanho do cérebro e de suas estruturas relacionadas.

O presente trabalho tem como objetivo, comparar a localização e tamanho do seio venoso sagital dorsal de cães braquicefálicos e mesaticefálicos, com relação à craniotomia lateral, com intuito de verificar sua posição nos diferentes tipos de crânio. 


\section{REVISÃO DE LITERATURA}

\subsection{HISTÓRICO}

O encéfalo é a terminação principal do sistema nervoso central e parte superior dos centros nervosos e encontra-se alojado na caixa craniana. $\mathrm{O}$ termo encéfalo é de origem grega e cérebro de origem latino que indica, especificamente, o prosencéfalo e o mesencéfalo. É a sede da sensibilidade dos movimentos voluntários e das faculdades intelectuais, e corresponde à zona mais volumosa do cérebro. Os hemisférios cerebrais são as duas metades que formam o cérebro. A superfície dos hemisférios cerebrais é escavada por numerosos sulcos e fissuras, que dividem a superfície de cada hemisfério em vários lobos.

Os registros mais remotos da extração do cérebro são do Egito. Os sacerdotes descartavam o cérebro durante a preparação do morto para a viagem até a outra vida. $\mathrm{O}$ coração permanecia no corpo por ser considerada a fonte do ser e da inteligência. Na antiguidade, o cérebro era valorizado por muitos, como uma concha de muco pulsante e abrigo para os espíritos dentro das câmaras vazias.

Por volta de 500 a.C, Alcmaeon, filósofo grego, declarou que "todos os sentidos estão ligados ao cérebro". Foi um marco na história da ciência, já que todos consideravam o coração como fonte do ser.

No diálogo Timaeus, Platão deu ao cérebro lugar central no cosmos. Descreveu-o como um ser vivo, criado por um artesão divino e detentor de alma imortal própria. Aristóteles (384-322 a.C), discípulo de Platão, adotou a escola centrada no coração. Observava em suas dissecações, que muitos animais não possuíam cérebro visível e mesmo assim eram capazes de interagir com o mundo. Declarou que "o cérebro modera o calor e agitação do coração". 
Em 332 a.C, Herófilo e Erasistrato descobriram o sistema nervoso. Através da dissecação de cadáveres humanos, observaram cordas finas e pálidas que formavam uma rede específica que brotava do crânio e da espinha. Os ventrículos foram definidos como câmaras no centro do cérebro que abrigavam o intelecto e os espíritos que fluíam para os nervos ocos e depois para os músculos, realizando os movimentos.

Galeno, médico grego, apoiou a idéia de Herófilo e Erasistrato sobre os espíritos dentro do cérebro, porém relata que estes espíritos passavam pela etapa de purificação ao atravessar a rede de vasos na base do crânio. Ali, tornavam-se espíritos animais capazes de pensar, sentir e movimentar-se. William Harvey, fisiologista, pai da circulação, definiu “a cabeça é redonda porque é a forma mais perfeita". Não acreditava em espíritos e concordava com Aristóteles a respeito do calor.

Em 1662, na cidade de Oxford, foi realizada primeira pesquisa moderna do sistema nervosa, nomeada "doutrina dos nervos", que mais tarde veio a ser conhecida, em latim, como Neurologia. Essa pesquisa foi feita por Thomas Willis, anatomista e médico inglês, juntamente com Christopher Wren que reproduzia no papel a estrutura do cérebro, e Richard Lower, que além do cérebro também estudava as transfusões sanguíneas. Willis dedicou-se ao estudo no cérebro durante décadas. Em suas dissecações observou uma vasta rede de vasos finos cobrindo todo o órgão e que as artérias do pescoço formavam um círculo antes de penetrar no cérebro. Ao realizar necropsia em um homem que sofrera de dores de cabeça durante uma fase de sua vida, Willis observou que uma das artérias carótidas estava bloqueada e a outra se apresentava distendida. Concluiu que o sangue irrigava todo o círculo e que fluía para todas as ramificações, mantendo constante a vascularização de todo o cérebro. Denominou os vasos de "Círculo de Willis". Também relata semelhança na arquitetura básica do cérebro dos homens e dos animais. A diferença no formato do encéfalo deveria corresponder à diferença na função. Em 1664, sintetizou todas as descobertas e publicou sua 
maior obra Cerebri Anatome ou Anatomia do Cérebro que foi referência para todos os cientistas da época e tornou-se "O livro imortal sobre o cérebro".

Em 1828, Félix Fegant, médico francês, concluiu que o peso do cérebro não influi sobre a inteligência, o que se acreditava até então. Segundo o professor Krauser, médico em Berlim, o peso médio do cérebro é de 1.650 g. Fergant pesou o cérebro do escritor francês Anatole France, e resultou em apenas 1017 g e de Dante, poeta italiano 1470g. Em 1899, no Popular Science Monthly, Joseph Smnis comprovou a não relação entre peso do cérebro e grau de inteligência. Smnis pesou cérebros de diversos cidadãos, como um vendedor de jornais, um aldeão escandinavo e de uma anã indiana de pouca inteligência e encontrou os seguintes resultados, $2.400 \mathrm{~g}, 2.340 \mathrm{~g}$ e $2.200 \mathrm{~g}$ respectivamente.

As patologias também foram descritas, como a epilepsia, que desde a antiguidade desperta interesse nos cientistas. Os babilônicos consideravam obra do demônio ou de algum espírito que partira. Na Grécia antiga, o faraó Amenofis IV ou Akhenaton era um homem doentio e sofria muito com ataques epiléticos, então considerados como evidentes sinais de contatos com o seu deus. A epilepsia era conhecida como "doença dos faraós". Os romanos repeliam os ataques com poções de sangue humano. Os europeus mesclavam tradições com ensinamentos da Bíblia, já que Jesus curara um epilético ao exorcizar os espíritos de seu corpo. Galeno explica que a epilepsia era causada pela bile negra que subia para o cérebro, na forma de vapor, onde era condensada em fluido entupindo os ventrículos e impedindo os espíritos de fluir para os nervos e assim, promovendo tremores desordenados. Willis procurou nova explicação para a epilepsia, mas nunca descartou os espíritos como causadores. Relata que os espíritos fluíam do cérebro para os nervos e que encontrariam partículas sulfurosas no sangue, desencadeando "explosão". Relacionou a descarga de espíritos com uma descarga elétrica e a explica no seu livro Patologia Cerebral. 
A prática cirúrgica mais antiga é a trepanação. No passado, a trepanação era aparentemente usada para aliviar pressão no cérebro causada por traumas, doenças ou libertar espíritos maus. Era praticada com um instrumento de pedra que realizava um orifício no crânio do paciente. Crânios encontrados e relatos de tribos datam de 5000 a.C. Alguns povos africanos realizam a trepanação atualmente, como cerimônia.

\subsection{ANATOMIA}

O cérebro é um órgão heterogêneo, subdividido em grupo de neurônios estruturalmente distintos e inter-relacionados. A lesão de pequeno número de neurônios com ação específica têm implicações clínicas sérias. O sistema nervoso apresenta propriedades fisiológicas únicas, como regulação da circulação sanguínea, ausência de sistema linfático, necessidade de substratos metabólicos, circulação especial (líquido céfalo raquidiano), dentre outras.

O crânio denota o formato da cabeça, abriga o cérebro e a maioria dos órgãos do sentido e porções dos sistemas respiratório e digestório. Compreende a inserção dos músculos faciais e da mastigação (NICKEL et al., 1986).

O crânio é constituído por muitos ossos, na sua maioria pares, que de forma congruente moldam-se para formar uma estrutura única e rígida. Os ossos possuem centros de ossificação independentes. São separados por estruturas de tecido fibroso e cartilagens, as suturas nos animais jovens. Com o amadurecimento do esqueleto, as suturas são substituídas por tecido conjuntivo (DYCE; SACK; WENSING, 1997).

Os ossos da cabeça são divididos em duas porções distintas. O neurocrânio é composto por ossos planos e irregulares unidos pelas suturas, compõem uma cavidade, a qual abriga o encéfalo. A calvária, parte mais alta do neurocrânio, é constituída por duas lâminas de 
substância compacta. A lâmina interna é muito frágil e delicada, podendo sofrer fraturas nos traumatismos e ocasionar a ruptura dos vasos situados entre a mesma e a dura mater. O viscerocrânio corresponde à porção da face e é formado por ossos irregulares e a mandíbula (NICKEL et al., 1986).

A origem dos ossos do crânio envolve três tipos de elementos estruturais: neurocrânio primordial, que é a cápsula cartilaginosa uniforme que abriga o cérebro; o viscerocrânio primordial, originalmente com esqueleto com cinco brânquias filogeneticamente remanescentes; e o desmocrânio, que promove o suporte para os outros dois (NICKEL et al., 1986).

Compõem o crânio, os seguintes ossos: occipital, interparietal, basisfenóide, pré esfenoide, pterigóide, temporal, parietal, frontal, etmoidal. (SACK; HABEL., 1994).

A proporção entre as porções aparentes e distintas do crânio (caudal e rostral) é variável entre raças, idade e conformação individual dos cães.

\subsubsection{Formato do crânio}

Os cães apresentam variações no formato e no tamanho do crânio, em razão da grande variedade racial. As diferenças estão relacionadas com o comprimento relativo da parte facial.

As raças são classificadas como dolicocefálicas, com a cabeça longa, braquicefálicas, cabeça curta e mesaticefálica, com a cabeça intermediária. Nos cães braquicefálicos, a parte facial e extremamente curta e o crânio é amplo e globoso; o ângulo naso frontal é saliente, a superfície dorsal é convexa e a crista sagital externa é reduzida. Geralmente são prognatas, diminuindo as dimensões da face, e com olhos amplamente espaçados. A face possui numerosas pregas de pele (GETTY, 1986). 
Os cães braquicefálicos são Pequinês, Pug, Boxer, Shitzu, Lhasa apso. Os mesaticefálicos têm como representantes cães das raças: Labrador, Terriers, Beagle, Poodle; enquento os dolicocefálicos são Daschund, Doberman, Whippet, Colie, Husky Siberiano (EMILY, 1994).

Para a classificação do tipo de crânio dos animais, são empregados dois índices e seu valores de referência: Índice Cefálico (IC) e Índice Crânio Facial (ICF)

O índice cefálico (IC) é a relação entre a largura e o comprimento do crânio. O comprimento do crânio é mensurado da crista nucal até a extremidade rostral da sutura interincisiva; e a largura é a medida entre os ápices dos arcos zigomáticos, dado pela fórmula:

IC $=100 \times$ largura do crânio / comprimento do crânio

Nos cães dolicocefálicos, o índice é abaixo de 50, enquanto em cães braquicefálicos chega a valores próximos a 100 .

O índice crânio facial, tem como referência a sutura frontonasal. Em cães braquicefálicos é igual ou pode ultrapassar 3. A média é 2 para cães mesaticefálicos.

ICF = comprimento crânio / comprimento face

O formato do crânio é o critério mais importante para determinar os padrões raciais. Vários estudos foram realizados para determinar o tipo de crânio em diversas espécies:caninos (MILLER, 1979), felinos (SARMA et al., 2002) e caprinos (KALITA et al., 2004). 
O Apêndice A - figura 1 evidencia a diferença do tipo de crânio mesaticefálico e braquicefálico.

Evans e Christenses (1993) classificaram crânios mesaticefálicos com IC médio de 52 em cães das raças Pastor Alemão, Beagle e Setter. Nos crânios dolicocefálicos, o IC médio foi de 39 para cães como Collie e Wolfhound Russo. Nos cães como Boston terrier e Pequinês, braquicefálicos, o IC médio foi de 81 .

Onar (1999) analisou trinta e três crânios de cães da raça Pastor Alemão entre quarenta e cinco e cento e cinco dias de idade. Os crânios foram macerados e realizadas as seguintes medidas morfométricas: peso, comprimento cranial, comprimento facial, largura máxima do neurocrânio, largura visceral, índice cefálico e volume cranial. O autor conclui que o comprimento cranial e viscerocranial aumentam com a idade, portanto o crânio dolicocefálico adquire sua forma característica conforme o crescimento dos filhotes.

O mesmo autor (2000), demonstrou que o crânio de cães da raça Kangal pertence ao grupo dolicocefálico. Através de medidas morfométricas em crânio de animais adultos macerados,foram encontrados os seguintes índices: Índice cefálico 50,29+/-1,033; índice cranial 46,05+/-2,213; índice facial 99,62+/-3,891; índice facial-1 81,67+/-3,667; índice basal 28,71+/-1,425; índice basal-1 57,91+/-1,365; comprimento 1,08+/-0,045; dentre outras.

A base cefalométrica da diferenciação de braqui, mesati e dolicocefálicos foi revisada por Lignerux et al. (1991). As proporções e os índices foram determinados através de vinte e quatro pontos cefálicos bem definidos. As diferenças foram marcantes no índice facial e as proporções face crânio. Os índices cefálicos encontrados para braqui (Boxer), mesati (Beagle) e dolicocefálicos (Collie) foram respectivamente: 78,7; 53,48 e 45.

Regodon et al. (1991) analisou 30 cães, sendo 10 braquicefálicos, 10 mesaticefálicos e 10 dolicocefálicos por meio de radiografias simples e contrastadas com sulfato de bário, e confirmou estatisticamente as diferenças morfométricas do crânio. Os autores descrevem 
diferenças raciais marcantes quanto ao território ósseo do neurocrânio, esplancnocrânio, além de diferenciações dentro da mesma raça, entre machos e fềmeas.

\subsubsection{Vascularização}

Os seios venosos são corredores venosos com paredes finas e rígidas, com escassas ou válvulas, localizados no interior canais ósseos do crânio. São divididos anatomicamente em sistema espinhal, que realiza a drenagem da medula espinhal; e sistema cranial, que drena o cérebro e alguma regiões extracranianas. Possuem importância clinica, pois carreiam sangue venoso para os pares de veias maxilares, jugulares internas e para os plexos venosos vertebrais (EVANS; CHRISTENSEN, 1993).

Lesões na rede venosa cerebral podem causar déficits severos como hemiplegia, hemorragias, coma e óbito do paciente. As veias cerebrais que apresentam maiores dificuldades para os acessos cirúrgicos estão localizadas na região do lobo temporal e ao longo da porção central do seio sagital dorsal (RHOTON, 2002).

Desde o início do século XX, estudos foram realizados para identificar e comparar o trajeto venoso. Hoffman ${ }^{1}$ (1901 apud REINHARD et al.,1962, p. 67) comparou anatomicamente o percurso da circulação venosa cerebral e vertebral entre espécies de vertebrados, incluindo o cão. Zimmerman ${ }^{2}$ (1936 apud REINHARD et al,1962., p. 67) publicou um estudo detalhado da anatomia dos seios venosos da dura mater.

O sistema venoso cerebral é dividido em dois grupos: superficial, que drena as superfícies corticais e o profundo, que realiza a drenagem das substancias branca e cinzenta e

\footnotetext{
${ }^{1}$ HOFMAN, M. Zur Vergleichenden Anatomie der Gehirn und Riickenmarsvenen der Vertebraten.

Zeitschr. F. Morphol. U. Anthropol., v.3, p.239-299, 1901.

${ }^{2}$ ZIMMERMANN, G. Uber die Dura Mater Encephali und die Sinus der Schaldelhohle des Hundes

Zeitschr. F. Anat. U. Entwicklungsgeschichte, v.106, p. 107-1037, 1936.
} 
conecta-se com ramificações das paredes dos ventrículos e da cisterna basal (RHOTON, 2002)

Segundo King (1987), há um grupo de seios denominados comunicantes. É representado pelo seio sigmóide, que recebe o grupo dorsal, via seio transverso e o grupo ventral, via seio petroso, para conectar-se com o sistema de seios espinhais.

O sistema de seios dorsais é composto por: seio sagital dorsal, seio sagital ventral, seio reto, seios transversos, seio occipital (MACHADO, 2000).

O seio sagital dorsal (Apêndice A - Figura 2) é ímpar e localiza-se na margem fixa da foice cerebral. Rostralmente, tem início na placa cribiforme por duas radículas que constituem o septo nasal, ao longo do seu comprimento recebe veias tributárias irregulares da circulação diplóica dorsal e veias das superfícies dorsal e medial dos hemisférios cerebrais. O seio sagital ventral situa-se na margem livre da foice do cérebro. Antes da inserção no forame ímpar, recebe o seio reto o que forma uma larga ramificação. Este corre pela foice do cérebro e é formado entre o forame impar e o esplênio do corpo caloso, pela junção da veia cerebral e as veias das regiões mediais dos lobos occipital direito e esquerdo. Após a passagem pelo forame ímpar, recebe os seios transversos direito e esquerdo o que se denomina seio confluente. O seio transverso corre lateralmente através do sulco e do canal transverso, junto à protuberância occipital interna. Na borda dorsal do sulco transverso, divide-se em seio temporal e seio sigmóide. O seio temporal corre na direção caudo lateral do osso petroso e estende-se para o forame retroarticular, emergindo como veia retroarticular até a veia maxilar. O seio sigmóideo, em forma de "S", corre na face dorso medial do osso petroso, atravessa o forame jugular em direção à fissura timpanoccipital. Realiza anastomose com o seio petroso ventral rostralmente ao canal petroccipital. A partir dessa anastomose, originam-se as veias jugular interna e vertebral (MACHADO, 2000). 
O sistema de seios ventrais, ou da base são: seios cavernosos, seios intercavernosos, seio esfenoparietal, seio petroso dorsal, seio petroso ventral, plexo basilar (MACHADO, 2000).

O seio cavernoso é par e localiza-se em cada lado do assoalho da fossa craniana média, desde a fissura orbitária até o canal petroccipital. Possui íntima relação com a artéria carótida interna, nervo abducente, troclear, óculo motor e ramo oftálmico do nervo trigêmio. Veias emissárias ligam o os seios com o plexo das veias oftálmicas e com a veia maxilar. Existem dois ou três seios intercavernosos que conectam os seios cavernoso direito e esquerdo, rostral e caudal e à glândula hipófise. O seio petroso dorsal dispõe-se de cada lado, ao longo da inserção da tenda do cerebelo na porção petrosa do osso temporal. Drena o sangue do seio cavernoso para o seio sigmóide. O seio petroso ventral percorre o sulco petroso ventral entre o seio cavernoso e o forame jugular. O plexo basilar localiza-se na porção basilar do occipital. Faz a comunicação dos seios petroso ventral e cavernoso com o plexo venoso vertebral interno (MACHADO, 2000).

O sistema de seios venosos da dura máter está representado no esquema do Apêndice B - Figura 3 e Apêndice C - Figura 4.

As veias cerebrais possuem inúmeras anastomoses. Por serem desprovidas de válvulas, realizam canais alternativos no caso de uma obstrução. As veias estão dispostas em dois grupos, superficial e profundo. O grupo superficial drena através das veias cerebrais dorsais para o sistema dorsal dos seios venosos, e as veias cerebrais ventrais para o seio petroso dorsal. No grupo profundo, as veias cerebrais profundas drenam a porção profunda dorsal dos hemisférios para a veia grande cerebral a então para o seio reto (KING, 1987).

Há uma extensa comunicação das veias da cabeça e do pescoço. O fluxo intracraniano pode fluir pela porção anterior do SVSD para as veias oftálmicas A maioria do fluxo 
sanguineo cerebral flui nos seios venosos da dura mater para as veia vertebrais e os sinusóides veretebrais (KUMAR et al., 1975)

A calota craniana e as meninges fornecem proteção rígida ao cérebro, porém restringem a capacidade de acomodação às mudanças de volume. Alterações na pressão arterial média (PAM) influenciam diretamente a pressão intracraniana (PIC). Segundo o princípio de Monro-Kellie, o líquido céfalo raquidiano, massa encefálica e volume sanguíneo mantém o volume constante e não são compressíveis (SANCHÉZ, 2003).

Reinhard et al., 1962; utilizou 28 cães mesocefálicos sem raça definida com peso entre 15 a $20 \mathrm{Kg}$ com idade variando entre 6 meses a 6 anos. Os animais foram eutanasiados, perfundidos com solução salina e preservados com formol a $10 \%$. A injeção de solução com látex e pigmentos coloridos foi realizada pela veia angular do olho, a fim de promover a coloração de todo sistema central e periférico. Quatro cães foram dissecados e dez foram macerados quimicamente para a identificação e descrição do sistema venoso. No estudo, os autores concluíram que arquitetura geral da circulação venosa cranial do cão é semelhante a do homem, porém existem diferenças marcantes quanto ao tamanho relativo de estruturas homólogas. A drenagem realizada pelo sistema de seios venosos deve ser ininterrupta.

A localização da vascularização cerebral é essencial para procedimentos cirúrgicos. Focos de oclusão e ou dilatação nos vasos colaterais podem indicar má malformações, neoplasias, tromboses (PLUHAR et al., 1997).

O mesmo autor descreve novo método para venografia com a finalidade principal de coloração do sistema venoso cerebral, via veia retroarticular ou veia retroglenóide. O cateter é inserido no animal, via veia jugular externa, guiado com auxilio do fluroscopio, pela veia maxilar, ultrapassando as veias superficiais temporais e auricular profunda até o nível da veia temporomandibular articular. 
Antes do advento da tomografia computadorizada e da ressonância magnética, a angiografia cerebral era o método de diagnóstico para detectar possíveis alterações na circulação cerebral. Como desvantagens, o animal precisava estar submetido à anestesia geral, os dois sistemas, arterial e venoso eram corados, e necessitava de equipamento radiográfico específico. A venografia é um método útil para diagnosticar alterações na circulação venosa cerebral, é menos complexa e invasiva que a angiografia.

Pluhar et al. (1997), comparou através da venografia, cães sadios e cães submetidos à craniotomia com oclusão do seio transverso esquerdo. Os animais sadios foram anestesiados e um cateter para angiografia pediátrico foi introduzido na veia jugular externa esquerda, próximo à confluência das veias maxilar e linguofacial. $\mathrm{O}$ contraste radiográfico a base de Iodo foi introduzido manualmente em bolus. As radiografias foram realizadas para identificação das estruturas venosas. O grupo dos cães da craniotomia também foi injetado com contraste, radiografados e, em seguida eutanasiados. O trajeto dos seios da dura mater foi descrito e confirmou-se a oclusão do seio transverso esquerdo como realizado na craniotomia.

Swayne et al. (1988) discorre sobre o infarto cerebral associado à trombose venosa em um cão, fêmea, sem raça definida de 10 anos. Apesar da pouca significância da obstrução venosa em cães, devido ao grande numero de anastomoses e ao sistema de válculas, a aparência idiopática da lesão exigiu atenção dos autores. O animal apresentava convulsões, hemiparesia (lado esquerdo), andar em círculos para o lado direito, cabeça inclinada para o lado esquerdo, reflexo pupilar retardado no olho direito; todos esses sinais, sem evidência de trauma craniano. À necropsia foram observadas as seguintes alterações: focos hemorrágicos e edemaciados na região do telencéfalo direito $\mathrm{Na}$ veia basal direita havia um trombo, ocluindo o ramo dorso lateral da veia. 


\subsection{DIAGNÓSTICO POR IMAGEM}

As radiografias simples podem ser realizadas para visualização do cérebro e do crânio. No entanto apresentam restrições devido à sobreposição das estruturas de interesse e á semelhança da densidade do tecido nervoso com tecidos moles. As posições básicas são: lateral, dorso-ventral, ventro-dorsal e oblíqua. A posição dorso ventral acentua a distorsão da imagem, já que o cérebro encontra-se mais afastado do filme. A calota craniana, os tecidos moles adjacentes e as estruturas ósseas extremamente compactas do crânio canino; associados aos diferentes tamanhos e formatos dos crânios, tornam a interpretação da radiografia muito difícil. São identificadas nas imagens simples, as seguintes moléstias: fraturas da calota ou ossos faciais, neoplasias com comprometimento ósseo e meningiomas (devido às calcificações), suspeita de displasia occipital síndrome vestibular (alterações nas bulas timpânicas) e hidrocefalia congênita (ORIBE, 2003; SPANO; HOERLEIN,1978).

As radiografias contrastadas (angiografia e venografia) são úteis na identificação de alterações radiográficas no cérebro. Na interpretação, alterações como aneurismas, tromboses e rupturas de vasos podem ser visualizados. Em contrapartida, as técnicas de injeção de contraste exigem anestesia do animal, o contraste é irritante e pode provocar alterações neurológicas; e hoje em dia são substituídas por outros métodos, como a tomografia computadorizada (ORIBE, 2003).

Os seios da dura mater podem ser identificados pela técnica de venografia através da injeção no seio venoso sagital dorsal e da veia angular do olho (OLIVER, 1969).

A tomografia computadorizada promove informações adequadas para o diagnóstico de lesões cerebrais. $\mathrm{Na}$ imagem da tomografia computadorizada podem-se identificar massas intracranianas, conteúdo nos ventrículos cerebrais e com auxilio de contrastes radiográficos, lesões vasculares (HATHCOCK; STICKLE, 1993). 
São avaliados na interpretação da imagem intracraniana, tamanho, forma, localização e densidade. O tecido cerebral é uniforme e homogêneo, com exceção do sistema ventricular, tentório cerebelar e da linha média (falx cerebri), que são estruturas visíveis e facilmente identificadas. As imagens podem apresentar assimetrias e variações individuais (HATHCOCK; STICKLE, 1993). .

Alterações no sistema ventricular como forma, posicionamento e densidade indicam sinais de massas no interior do cérebro. Áreas hemorrágicas agudas tornam-se radiodensas e com a dissolução do coágulo, áreas radiolucentes são visíveis semelhantes a edema (HATHCOCK; STICKLE, 1993).

Fike et al. (1981) estudou a anatomia do cérebro canino utilizando a imagem da tomografia computadorizada. Refere que alguns pontos de referência como o tentório ósseo, porção petrosa do osso temporal e as bulas timpânicas são de fácil identificação. Porém algumas estruturas possuem densidade semelhante e é necessário o uso de substâncias contrastantes como auxílio diagnóstico no exame.

Regodon et al. (1992) analisou o volume do crânio de 30 cães da raça Pequinês (15 machos e 15 fêmeas), através das imagens de tomografia computadorizada. O volume foi calculado pelo método numérico de Simpson, que calcula a soma das áreas. A média encontrada foi de $64,10-65,49 \mathrm{~cm}^{3}$ para machos e $58,10-59,49 \mathrm{~cm}^{3}$ para fêmeas, comprovando o dimorfismo sexual em uma mesma raça.

Vite et al. (1997) quantificou o volume ventricular utilizando a ressonância magnética. O volume ventricular foi determinado pela somatória das medidas dos ventrículos laterais, terceiro e quarto ventrículos, arqueduto mesencefálico e forame interventricular. O volume cerebral foi determinado subtraindo-se o volume ventricular total do volume intracraniano, incluindo as meninges e a vascularização. Para determinar o valor das áreas, os autores utilizaram a área conhecida em pixels multiplicada pela espessura do corte. Foi observado 
aumento nos ventrículos laterais dos Buldogues em relação aos Beagles, porém estes não apresentavam sinais de hidrocefalia.

A área (em mm2) de cada ventrículo lateral e hemisférios cerebrais foi manualmente sublinhada em uma imagem realizada pela ressonância magnética ao nível da aderência intertalâmica. Os animais foram divididos em três grupos: Grupo 1: Yorkshire sem sintomas, Grupo 2: Yorkshire com sintomas de hidrocefalia e Grupo 3 Pastor Alemão sem sintomas. A classificação pelo formato da cabeça do animal pode ser confusa devido ao reduzido tamanho do esplâniocrânio sem o envolvimento do neurocrânio e vice-versa. A dilatação do ventrículo nos dois grupos de Yorkshire demonstra o mínimo espaço do neurocrânio, e conseqüentemente não há drenagem suficiente acarretando em doenças metabólicas (RATSH et al., 2001).

Como auxilio da tomografia computadorizada, Onar et al. (2002), determinou as medidas craniométricas, no próprio aparelho, de catorze animais da raça Pastor Alemão entre 100 e 120 dias de idade. As medidas foram compatíveis como o desenvolvimento de um cão dolicocefálico. O máximo comprimento do neurocrânio aumenta com o crescimento do filhote, enquanto a cavidade craniana cresce lentamente.

Através da ressonância magnética e da tomografia computadorizada é possível diagnosticar moléstias com localização cerebral de natureza orgânica e funcional, que podem acometer tanto a espécie humana quanto animal. Segundo Colaço et al. (2003), as imagens substituem os resultados obtidos através de métodos invasivos com contraste radiográfico. $\mathrm{Na}$ medicina veterinária o uso da ressonância magnética é limitado pelo alto custo dos equipamentos e instalações e pouca adaptação para os animais domésticos. 


\subsection{PATOLOGIA}

As desordens neurológicas dos animais são conhecidas desde o século XVII, porém a neuropatologia veterinária é recente. Antes, muitos diagnósticos eram realizados durante a necropsia.

O SNC pode ser acometido por moléstias infecciosas; virais, bacterianas, fúngicas e parasitárias; vasculares, neoplásicas, congênitas, degenerativas, traumáticas e tóxicas. Dentre as principais enfermidades podemos citar: cinomose, meningites, astrocitomas, hidrocelafia, epilepsia e os traumas cranianos (HOERLEIN; VANDEVELDE, 1978).

As neoplasias do SNC podem ser primárias, na qual as células tumorais desenvolvemse a partir do cérebro e ou das meninges; e as secundárias, em que desenvolvem em outras estruturas da cabeça, afetam o cérebro por compressão e ainda metástases de outras localizações do corpo (HOERLEIN; VANDEVELDE,1978).

As neoplasias do SNC ocasionam hipertensão intracraniana devido à progressão de fatores como: comprometimento vascular, obstrução ventricular e compressão do encéfalo propriamente dita (SANCHÉZ, 2003).

A incidência de tumores cerebrais é alta em cães com idade média de 9 anos. As raças acometidas são Golden Retriver (16\%), SRD (12\%), Labrador (10\%), Boxer (9\%), Collie (6\%), Doberman (5\%), Standard Schnauzer (4\%) e Airedale Terrier (3\%). Os animais apresntaram convulsões, ataxia, andar em círculos, letargia, anorexia, agressividade, mudança de comportamento, ptialismo, Head Tilt como sinais clínicos principais. O diagnóstico histopatológico revela que dos 97 animais estudados, 46\% apresentavam meningioma, 13\% astrocitoma, $10 \%$ tumor no plexo coróide, $10 \%$ tumor da pituitária, $4 \%$ oligoglioma, $10 \%$ outros tipos de neoplasias (BAGLEY et al., 1999). 
Gage e Hoerlein (1968) referem o tratamento cirúrgico da hidrocefalia pelo método de "Shunt" ventriculoatrial. A hidrocefalia é caracterizada pelo acúmulo patológico do líquido cérebro espinhal nos ventrículos cerebrais. As raças mais acometidas pela moléstia são Chihuahua, Boston Terrier, Poodle e Yorkshire. Possui duas formas de apresentação: congênita, na qual o crânio é alargado pelo não fechamento das fontanelas e suturas; e a forma adquirida, que em descorrência do aumento da pressão intracraniana (PIC) pode promover a abertura das suturas cranianas. Após o diagnóstico conclusivo, a cirurgia é o tratamento permanente mais efetivo. É realizada através de um “shunt” inserido nos ventrículos cerebrais para outro local, como o SVSD ou a veia cava superior, a fim de realizar a absorção. Para o procedimento cirúrgico são necessários cuidados com a anestesia e assepsia. O orifício no crânio é realizado de 2 a $4 \mathrm{~cm}$ da linha média dorsal. Os autores referem, dos 21 cães submetidos à cirurgia, $86 \%$ de sucesso pós cirúrgico. 


\subsection{TÉCNICAS CIRÚRGICAS}

Devido ao incremento de métodos, como a tomografia computadorizada e a ressonância magnética, o diagnóstico de alterações intracranianas tornou-se conclusivo. Com isso, a correção cirúrgica associada ao diagnóstico preciso e precoce é possibilidade com objetivo de aumentar a sobrevida do paciente. As técnicas utilizadas na neurologia humana podem ser adaptadas à veterinária, considerando-se algumas alterações anatômicas.

Estudos preliminares foram realizados em 1963, por Hoerlein et al. Os autores descreveram considerações pré e pós cirúrgicas, além das técnicas mais utilizadas.

As técnicas de craniotomia e craniectomia estão descritas e possuem diferentes acessos: rostrotentorial, transfrontal e caudotentorial (subocciptal), de acordo com a localização da lesão (HOERLEIN; OLIVER JR, 1978; OLIVER JR, 1968; SEIM, 2005; SHORES, 1984).

As principais indicações para a cirurgia incluem trauma crânio encefálico, neoplasias intracranianas, hidrocefalia, biópsia cerebral e epilepsia (HOERLEIN; OLIVER JR, 1978; OLIVER JR, 1968; SEIM, 2005; SHORES, 1984).

O acesso ao encéfalo é determinado pela localização e extensão da lesão. Os seios venosos: sagital dorsal e transversos são pontos anatômicos de referência para o acesso cirúrgico à calota craniana (HOERLEIN; OLIVER JR, 1978; SEIM, 2005; SHORES, 1984).

O animal é posicionado em decúbito esternal, com a cabeça elevada, com auxílio de um suporte, a fim de não obstruir o fluxo sanguíneo cerebral por compressão das veias jugulares. A cabeça do animal pode ser rotacionada para facilitar a exposição dependendo do acesso (SHORES, 1984).

Oliver $\operatorname{Jr}$ (1968) descreve as técnicas de craniotomia realizadas em 47 animais a fim de estabelecer a exposição das áreas do encéfalo canino. Os cães utilizados possuíam formatos 
de crânios variados, entre dolicocefálicos a braquicefálicos. As técnicas tinham como objetivo expor as seguintes áreas do encéfalo: lobo parietal, lobo occipital, estruturas dorsais médio sagitais, estruturas ventrais médio sagitais, cerebelo, medula oblonga, e sistema ventricular. Os acessos cirúrgicos utilizados foram: rostrotentorial (lateral), bilateral rostrotentorial (lateral), caudotentorial (suboccipital) e ventral; e serão descritos a seguir:

$\mathrm{Na}$ abordagem rostrotentorial (lateral), o acesso ao crânio é feito nas porções dos ossos parietal, frontal e temporal ou esfenóide. A técnica é utilizada para expor o lobo parietal, lobo occipital, glândula pituitária, cerebelo (porção anterior) e ventrículos laterais (OLIVER JR.,1968)

A incisão, com formato de "ferradura" ou "U" é feita no ponto caudal ao canto do olho à protuberância occipital externa, seguindo ao longo da crista sagital externa. A musculatura frontal e os músculos da orelha são rebatidos. O músculo temporal é rebatido, a fim de expor a superfície lateral do crânio. Deve-se evitar o ramo occipital da artéria auricular. No caso de ampla exposição, o arco zigomático pode ser seccionado. Quatro orifícios são perfurados, com perfuratriz pneumática de alta rotação, para promover um flap do osso da calvária. O tamanho e a localização do flap varia com o objetivo da cirurgia. A dura mater é divulsionada, separando-se do flap do osso do crânio. Hemorragias dos vasos locais devem ser evitadas e controladas com esponjas de gelatina que contem material coagulante. O flap ósseo é mantido em solução salina aquecida, caso necessite ser reposicionado. A incisão na dura mater aderida ao crânio é feita com instrumental delicado e com $5 \mathrm{~mm}$ da margem da craniotomia (OLIVER JR., 1968).

A artéria meningeana média deve ser ligada próximo à base com fio absorvível, para evitar hemorragias. Hemorragias parenquimais, da pia mater e da membrana aracnóide devem ser controladas com eletrocauterio ou esponjas de trombina. O tecido cerebral remanescente é lavado com solução salina estéril e aquecida (SEIM, 2005). 
A dura mater é suturada no padrão simples interrompido em duas camadas com fio de seda 5-0. Se necessário, pode-se utilizar a fáscia do músculo temporal como substituta da dura (OLIVER JR., 1968)

O reposicionamento do flap ósseo é feito com fio de aço ortopédico ou fio monofilamento não absorvível 0 a 2-0. O músculo temporal é suturado com um padrão interrompido e com fio monofilamento absorvível 2-0 a 3-0. O tecido subcutâneo e a pele são suturados de maneira rotineira (SEIM, 2005).

Com o intuito de evitar complicações, as superfícies cerebrais devem ser mantidas úmidas e com mímina quantidade de esponjas de gelatina, já que é um excelente material de cultura, evitando assim promover infecções (OLIVER JR., 1968).

A abordagem rostrotentorial (lateral) é uma técnica fácil, segura e pode ser realizada nos dois lados do crânio (rostrotentorial bilateral), com cautela, deixando uma lâmina da calota craniana na região mediana para proteger o seio venoso sagital dorsal (OLIVER JR., 1968).

Hoerlein e Oliver $\mathrm{Jr}$ (1978) descrevem a margem de segurança de 0,5 cm rostral a crista nucal, para evitar o seio venoso transverso e 1,0 cm lateral à linha mediada dorsal para evitar o seio venoso sagital dorsal. Outros autores como Seim (2005) apresentam a distância de modo generalizado de 0,5 a 1,0 cm dos pontos de referência, como por exemplo a cista sagital externa.

A complicação mais grave da craniotomia é o edema cerebral. No experimento de Oliver Jr (1968), dos quarenta e três cães, onze apresentaram edema, através da ligadura do seio venoso sagital dorsal. Os animais morreram após o procedimento. Um animal sobreviveu e apresentou sinais de aumento de pressão intracraniana quatro dias após a cirurgia.

A craniotomia caudotentorial (suboccipital) consiste na técnica utilizada para exposição da porção caudal do cerebelo, porção dorsal da medula oblonga e quarto ventrículo 
(OLIVER JR., 1968). É uma abordagem para porção mais caudal do crânio, região na qual o SVSD une-se com os seios transversos direito e esquerdo.

A abordagem caudotentorial é geralmente bilateral, devido ao pequeno tamanho do local. Alguns animais, ( $\mathrm{p}$ ex Boxers, Pug, Boston Terrier) possuem musculatura muito desenvolvida, fato que se recomenda a incisão em curva e não na linha média. Pelo fato de ser uma técnica com alto risco de laceração e hemorragia, e também devido a pouca exposição das estruturas de interesse, indicam-se as abordagens combinadas, como rostrotentorial extendida.

Wet et al. (1982) propôs o acesso cirúrgico á fossa rostral cranial através da craniotomia trasnfrontal radical. A técnica promove ampla exposição, o que possibilita identificação das estruturas, hemostasia adequada e menor risco de contaminação. Porém, segundo o autor, algumas precauções devem ser consideradas na região: forte aderência da dura mater e a profundidade do sulco do SVSD na fissura mediana, principalmente animais mais velhos.

Shell et al. (1983), em seu trabalho, relata a extração cirúrgica de meningioma após detecção através da tomografia computadorizada. O felino, da raça Manx, 14 anos apresentando lesões compatíveis com anormalidades no lobo frontal direito e/ou lobo talâmico rostral. Foram realizadas radiografias, eletroencefalografia e análise do fluido cérebro espinhal além da tomografia computadorizada. $\mathrm{O}$ exame evidenciou um aumento do ventrículo esquerdo, e após a injeção do contraste, houve um aumento da densidade de área no lobo fronto parietal e área occipital direita compatível com meningioma. O animal foi submetido à craniotomia transfrontal, como descrito na literatura, para ressecção da neoplasia. A margem de segurança para SVSD foi de $0,5 \mathrm{~cm}$ da crista sagital externa.

Lawson et al. (1982) relata diagnóstico e tratamento cirúrgico de 10 casos de meningioma em gatos. Os animais apresentavam disfunções neurológicas progressivas e 
insidiosas. O diagnóstico foi confirmado por radiografias. O procedimento de craniotomia foi realizado em todos os animais, como descrito por Hoerlein (1968). O autor relata que em alguns casos a localização da neoplasia é adjacente ao seio venoso sagital dorsal. Nesses casos a cirurgia deve ser cautelosa e há grande risco de laceração do seio venoso.

Em seu trabalho, Regodon et al. 1996, propôs uma nova técnica para coleta ou administração de substâncias no CSF. Comparou 12 cães com diferentes conformações cranianas (4 Pointer, 4 Greyhound e 4 Pequinês), sem especificidade quanto a o sexo, entre 3 a 5 anos. Os animais foram anestesiados e monitorados para a realização da trepanação a fim de promover o acesso à cavidade do bulbo olfatório. Um trocater estéril foi introduzido perpendicularmente ao osso frontal, atravessando as seguintes camadas: seio frontal rostral, lâmina interna do osso frontal, dura mater e parede adjacente do bulbo olfatório, para a deposição do contraste radiográfico. O recesso olfatório do ventrículo lateral está localizado a $27+/-2 \mathrm{~mm}$ nos cães Pointer, 25+/- $2 \mathrm{~mm}$ nos Greyhound e $22+/-2 \mathrm{~mm}$ nos pequineses, em relação a lamina externa do osso frontal. O trabalho evidencia a presença do recesso olfatório no ventrículo lateral e sua possível utilização no acesso cirúrgico aos ventrículos laterais.

Durante o período de 5 anos avaliou, Niebauer et al. (1991) avaliou cães e gatos submetidos à cirurgia intracraniana. Os animais foram avaliados neurologicamente e através da tomografia computadorizada 1 a 7 dias antes da cirurgia (Neoplasias intracranianas $=25$, Lesões inflamatórias cerebrais $=3$ ). Os sinais clínicos da moléstia evidenciam a localização das lesões no cérebro. Lesões na fossa cranial/caudal e cerebelo demonstram alterações no equilíbrio e mobilidade. Lesões na fossa cranial anterior e média apresentam convulsões. A maioria dos animais foi tratada com corticosteróides e/ou anticonvulsivantes. Os animais que apresentaram piora do quadro apesar do tratamento conservativo, lesões de fácil acesso no crânio e com possibilidade de excisão completa da massa tumoral foram indicados para a cirurgia. As craniotomias foram realizadas como descritas por Hoerlein. O limite do flap 
ósseo tem como referência os seios venosos (seio venoso sagital dorsal, seios venosos transversos, seio venoso confluente e seio petroso dorsal).A dura mater não foi reposicionada de maneira rotineira. Em alguns animais, principalmente os mais velhos, a membrana é aderida ao endósteo e pode ser lacerada durante a manipulação. Em outros acasos, como nos meningiomas e outros tumores infiltrativos, há comprometimento da região e faz-se necessária a sua retirada. Os animais foram acompanhados no período pós cirúrgico durante 48 horas. A média de sobrevivência foi de 212 dias $(1$ ano $=39 \%, 2$ anos $=20 \%)$. 34 craniotomias foram realizadas (19 rostrotentorial, 6 suboccipital, 5 rostrotentorial + transfrontal, 3 rostrotentorial + caudotentorial, 1 transfenoidal) com $81 \%$ de sobrevivência ao pós operatório imediato (1 semana). A cirurgia intracraniana é um procedimento que depende do tipo e severidade da lesão além da capacidade e experiência da equipe cirúrgica. Acreditase que o não reposicionamento da dura mater pode ser vantajoso, já que ocorre um aumento da pressão intracraniana (PIC) no período pós operatório.

Bagley et al. (1996), determinou o efeito da craniectomia e durotomia na PIC em cães clinicamente normais. Utilizou 2 experimentos com 6 cães. Em um experimento realizou craniectomia e durotomia como descrito na literatura e concomitantemente administrou diuréticos e corticosteróides além da hiperventilação. A PIC foi monitorada através de um cateter inserido cirurgicamente. No outro experimento foi realizada somente a craniectomia e durotomia. Em ambos os procedimentos, os autores realizaram a técnica descrita por Hoerlein (1978). Os resultados demonstraram que a PIC média inicial foi de 12+/-3 e 11+/-2 nos experimentos A e B respectivamente. Nos cães do experimento A, a PIC média foi de 2+/-1; e nos cães do experimento B 2+/-, o que demostra que a craniectomia/durotomia são métodos úteis para reduzir a PIC e podem ser utilizados como tratamento.

A técnica transfrontal bilateral modificada foi descrita por Glass et al. (2000). A técnica promove o acesso á placa cribiforme, bulbo olfatório e aos lobos frontais do cérebro. 
É um procedimento de difícil realização, já que exige o reposicionamneto de dois ossos e há o grande risco de laceração do seio venoso sagital dorsal, durante a confecção da porção rostro tentorial. O tamanho e forma do seio frontal são diferentes entre as raças. Os animais braquicefálocos possuem o seio frontal muito pequeno enquanto os cães dolicefálicos possuem o seio grande e largo.

Parker e Cunningham (1972) descrevem o acesso cirúrgico ao córtex cerebral frontal através do seio frontal no cão. A superfície ventral do seio frontal comunica-se diretamente com o córtex cerebral frontal. O flap para a craniotomia é realizado iniciando no osso frontal $1 \mathrm{a} 2 \mathrm{~cm}$ caudal ao seio frontal e estende-se dentro do seio frontal. Os autores ressaltam a importância da margem de segurança de $0,5 \mathrm{~cm}$, direcionando a incisão lateralmente, a fim de evitar laceração do seio venoso sagital. Há risco de infecção e conseqüentemente a meningite. 


\section{MATERIAL E MÉTODO}

Para a realização do presente trabalho foram utilizados 16 (dezesseis) cadáveres, da espécie canina, sendo 08 (oito) braquicefálicos da raça Boxer e 08 (oito) mesaticefálicos de raças diversas; sem distinção de sexo e idade. Os animais vieram à óbito e foram disponibilizados pelo Hospital Veterinário da Universidade de São Paulo. Os animais que tiveram moléstias neurológicas, confirmadas no diagnóstico foram descartados do estudo.

\subsection{DELINEAMENTO EXPERIMENTAL}

A realização deste experimento consiste em três partes que serão descritas nos próximos itens.

\subsection{1- Perfusão dos vasos sangüíneos}

Os animais que vieram à óbito foram higienizados, os pêlos raspados e posicionados em decúbito dorsal. A pele foi incisada e os tecidos subcutâneo e muscular divulsionados para permitir o acesso à Veia Jugular externa e à Artéria Carótida comum em ambos os antímeros. Posteriormente, cateter intravenoso de calibre $16 \mathrm{GA} \times 1,88 \mathrm{IN}^{3}$ foi posicionado em cada Artéria Carótida Comum (direita e esquerda), e um equipo foi posicionado em cada Veia Jugular externa (direita e esquerda), ambos em direção à cabeça. Estes foram fixados aos vasos sangüíneos com auxílio de fio de algodão. Imediatamente posterior aos cateteres e equipos, os vasos sangüíneos foram suturados com fio de algodão, obliterando a região da cabeça.

\footnotetext{
${ }^{3}$ BD Angiocath ${ }^{\mathrm{TM}}$
} 
Foi realizada lavagem do sistema vascular sangüíneo através de perfusão de Heparina em Solução salina $\left(\mathrm{NaCl}\right.$ 0,9\%) à $27^{\circ} \mathrm{C}$ lentamente, via artérias Carótidas comuns direita e esquerda, simultaneamente, até que a solução fisiológica saísse pelas veias jugulares incolor. Utilizou-se um volume de aproximadamente $10 \%$ do peso corpóreo total de cada cadáver em velocidade de 100 gotas por minuto.

Após a lavagem do sistema os equipos fixados ao sistema venoso foram substituídos por cateteres intravenosos calibre 20 e então se iniciou a injeção de Látex-neoprene com pigmento colorido ${ }^{4}$ e Sulfato de bário ${ }^{5}$ nas veias. A injeção foi realizada por meio de seringas de $60 \mathrm{ml}$ a uma velocidade de $5 \mathrm{ml}$ por minuto, acopladas em um sistema com uma torneira de três vias e um esfingnomanômetro, com pressão constante de $20 \mathrm{~mm} \mathrm{Hg}$, até que os vasos periféricos fossem completamente repletos.

Os cadáveres foram mantidos em refrigeração por um período de aproximadamente 24 horas. Posteriormente, a cabeça e o pescoço, foram separados do restante do corpo e fixados através de injeção intra-muscular de solução de Formalina $10 \%$ e conservadas submersas na mesma solução por um período de 72 horas.

\subsubsection{Análise macroscópica}

Os crânios dos animais foram mensurados, com paquímetro digital ${ }^{6}$ no seu comprimento da crista nucal até a extremidade rostral da sutura interincisiva, e a largura, nos ápices dos arcos zigomáticos a fim de determinar o índice cefálico (IC). (Apêndice D Figuras 5 a 7)

\footnotetext{
${ }^{4}$ Sulvinil Glasurit do Brasil Ltda

${ }^{5}$ Bariogel ${ }^{6}$ - Cristália

${ }^{6}$ Digimess ${ }^{\circledR}$
} 


\subsection{3- Imagens Radiográficas}

\subsubsection{RX contrastado}

As radiografias foram realizadas com a peça anatômica na posição pronada, com incidência dorso ventral e também na posição lateral esquerda, com incidência latero lateral. As radiografias têm o intuito de verificar a perfusão do contraste pelo sistema venoso para a posterior realização da tomografia computadorizada (Apêndice E - Figuras 8a e 8b e Apêncice F - Figura 9a e 9b).

\subsubsection{Tomografia computadorizada}

Para o estudo através da tomografia computadorizada, as peças foram posicionadas em posição pronada, de modo a manter a simetria do crânio, para a incidência dorso ventral e realização dos cortes (Apêndice G - Figura 10a e 10 b e Apêndice H - Figura 11a e 11b).

O exame tomográfico foi realizado em equipamento CT-MAX $640^{7}$ de terceira geração. As imagens foram fotografadas em câmera multiformato MFC640 5 , em filmes de marcas Kodak Ektanscan $\mathrm{M}^{8}$ tamanho $35 \mathrm{x} 43 \mathrm{~cm}$ os quais foram revelados e fixados em Processadora Automática RPX-OMAT Processor ${ }^{9}$.

\footnotetext{
${ }^{7}$ General Eletric

${ }^{8}$ Kodak Brasileira Com. Ind LTDA

${ }^{9}$ Eastman Kodak Company
} 


\subsubsection{Análise das imagens}

As imagens das 16 peças anatômicas foram fotografadas com máquina digital Sony Cyber-shot T3, 5.1 Mega Pixels, Zoom digital 3x e auxilio do negatóscópio. As imagens foram transferidas para o software KS-400 para posterior análise e mensurações.

Utilizando a ferramenta geometric calibration e a escala da imagem tomográfica, fez-se a calibragem da escala. Quando necessário, para cada corte calibrava-se a escala (Apêndice I -Figura 12).

Através da ferramenta set features, determinou-se os seguintes parâmetros: área do SVSD $\left(\mathrm{mm}^{2}\right)$, distância entre o ponto médio do SVSD e o ápice da calota (perpendicular)(mm), linha horizontal entre o ponto médio do SVSD e a porção mais externa do osso do crânio, originando assim, duas medidas horizontais em milímetros (mm) e também a delimitação em mm do contorno da calota craniana de cada lado do SVSD (Apêndice I Figura 13 e Apêndice J - Figuras 14 e 15) ; esquematizados a seguir:

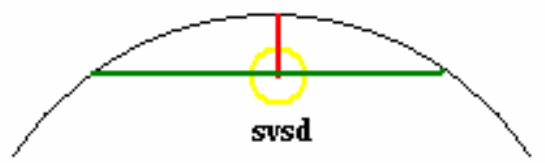

em que:

svsd (amarelo) - Seio venoso sagital dorsal;

Vermelho - perpendicular do ponto médio do SVSD ao ápice da calota craniana (D1);

Verde - horizontal do ponto médio do SVSD em relação à calota craniana (lado esquerdo e direito) D2 e D3;

Preto - segmento circular (lado esquerdo e direito) D4 e D5. 
O trajeto do seio venoso sagital dorsal foi identificado em cada peça anatômica através dos cortes das imagens. Foram identificadas as seguintes características: início, maior calibre e final do seio venoso.

\subsubsection{Análise estatística}

Os dados obtidos na morfometria foram analisados e comparados através da média e do desvio padrão.

As mensurações das distâncias do SVSD em relação à calota craniana em mm foram avaliados com auxílio do programa estatístico computadorizado Minitab release 14 version $14.20^{8}$

Foi utilizado o teste $t$ de Student, visto que as variáveis (Área, D1, D2, D3, D4 e D5) possuem distribuição normal ou aproximadamente normal. O valor de $t$, para o nível de significância de 5\% e com $n-1$ graus de liberdade foi determinado. Para tal análise adotou-se o seguinte modelo estatístico:

$$
\mathrm{t}=\mu_{2}-\mu_{1} / \sqrt{\mathrm{s}^{2}\left(1 / \mathrm{n}_{1}+1 / \mathrm{n}_{2}\right)}
$$

em que:

$\mathrm{t}=$ valor de $\mathrm{t}$

$\mu_{1=\text { média grupo } 1 ;}$

$\mu_{2}=$ média grupo 2 ;

$\mathrm{s}^{2=}$ variância ponderada;

$\mathrm{n}_{1}=$ número de elementos grupo 1 ;

$\mathrm{n}_{2}=$ número de elementos grupo 2. 


\section{RESULTADOS}

Os resultados foram divididos em duas partes: análise macroscópica da peça anatômica e análise da imagem tomográfica, como serão descritos a seguir:

\subsection{ANÁLISE MACROSCÓPICA}

Os resultados obtidos na mensuração do comprimento e largura dos crânios mesaticefálicos e o IC estão apresentados na tabela 1.

\begin{tabular}{c|cccc|}
\hline Tabela 1 - & \multicolumn{5}{l}{$\begin{array}{l}\text { Medidas em mm do comprimento, largura e índice cefálico dos mesaticefálicos } \\
\text { - São Paulo }-2006\end{array}$} \\
\hline \multicolumn{1}{c}{$\boldsymbol{N}^{\boldsymbol{0}}$ crânio } & Raça & Comprimento & Largura & IC \\
\hline 1 & SRD & 99,86 & 77,33 & 77,438 \\
2 & SRD & 145 & 114,81 & 79,179 \\
3 & Pinscher & 71,90 & 63,30 & 88,038 \\
4 & SRD & 146,26 & 115,84 & 79,201 \\
5 & SRD & 116,17 & 97,09 & 83,575 \\
6 & SRD & 139,69 & 108,87 & 77,936 \\
7 & Rotweiller & 194,01 & 154,15 & 79,454 \\
8 & Labrador & 168,7 & 123,76 & 73,343 \\
\hline Média & & $\mathbf{1 3 5 , 1 9 8}$ & $\mathbf{1 0 6 , 8 9}$ & $\mathbf{7 9 , 7 7 1}$ \\
Desvio padrão & & $\mathbf{3 8 , 6 1 4}$ & $\mathbf{2 8 , 1 1 6}$ & $\mathbf{4 , 3 7 0}$
\end{tabular}

Na tabela 1, verificou-se o comprimento médio de $135,198 \pm 38,614$, a largura de $106,89 \pm 28,116$. Baseado nessas medidas temos o IC médio de 79,771 $\pm 4,370$. O IC encontra-se nos valores de 50 a 100 como proposto na literatura. Os valores estão dentro da normalidade em até duas vezes o desvio padrão e sem diferença estatística. 


\begin{tabular}{c|cccc}
\hline Tabela $2-$ & \multicolumn{4}{l}{ Medidas em mm do comprimento, largura e índice cefálico dos braquicefálicos } \\
& - São Paulo -2006 & \\
\hline \multicolumn{1}{c}{$\boldsymbol{N}^{\boldsymbol{0}}$ crânio } & Raça & Comprimento & Largura & IC \\
\hline 1 & Boxer & 195,06 & 154,62 & 79,267 \\
2 & Boxer & 160,44 & 146,96 & 91,598 \\
3 & Boxer & 170,72 & 136,72 & 80,084 \\
4 & Boxer & 147,84 & 149,54 & 101,149 \\
5 & Boxer & 144,29 & 133,50 & 92,522 \\
6 & Boxer & 154,42 & 138 & 89,366 \\
7 & Boxer & 136,13 & 128,57 & 94,446 \\
8 & Boxer & 127,60 & 129,55 & 101,528 \\
\hline Média & & $\mathbf{1 5 4 , 5 6 2}$ & $\mathbf{1 3 9 , 6 8 2}$ & $\mathbf{9 1 , 2 4 5}$ \\
Desvio padrão & & $\mathbf{2 1 , 2 2 3}$ & $\mathbf{9 , 6 3 0}$ & $\mathbf{8 , 3 4 4}$
\end{tabular}

Na tabela 2, dos crânios braquicefálicos, o comprimento médio mensurado é de $154,562 \pm 21,223$, a largura média 139,682 \pm 9,630, o que resulta no IC de 91,245 $\pm 8,344$. Não há diferença estatística entre os animais pelo fato da amostra apresentar pouca dispersão. Todos os crânios apresentam o IC dentro de duas vezes o desvio padrão da amostra (figuras 17 a 21$)$

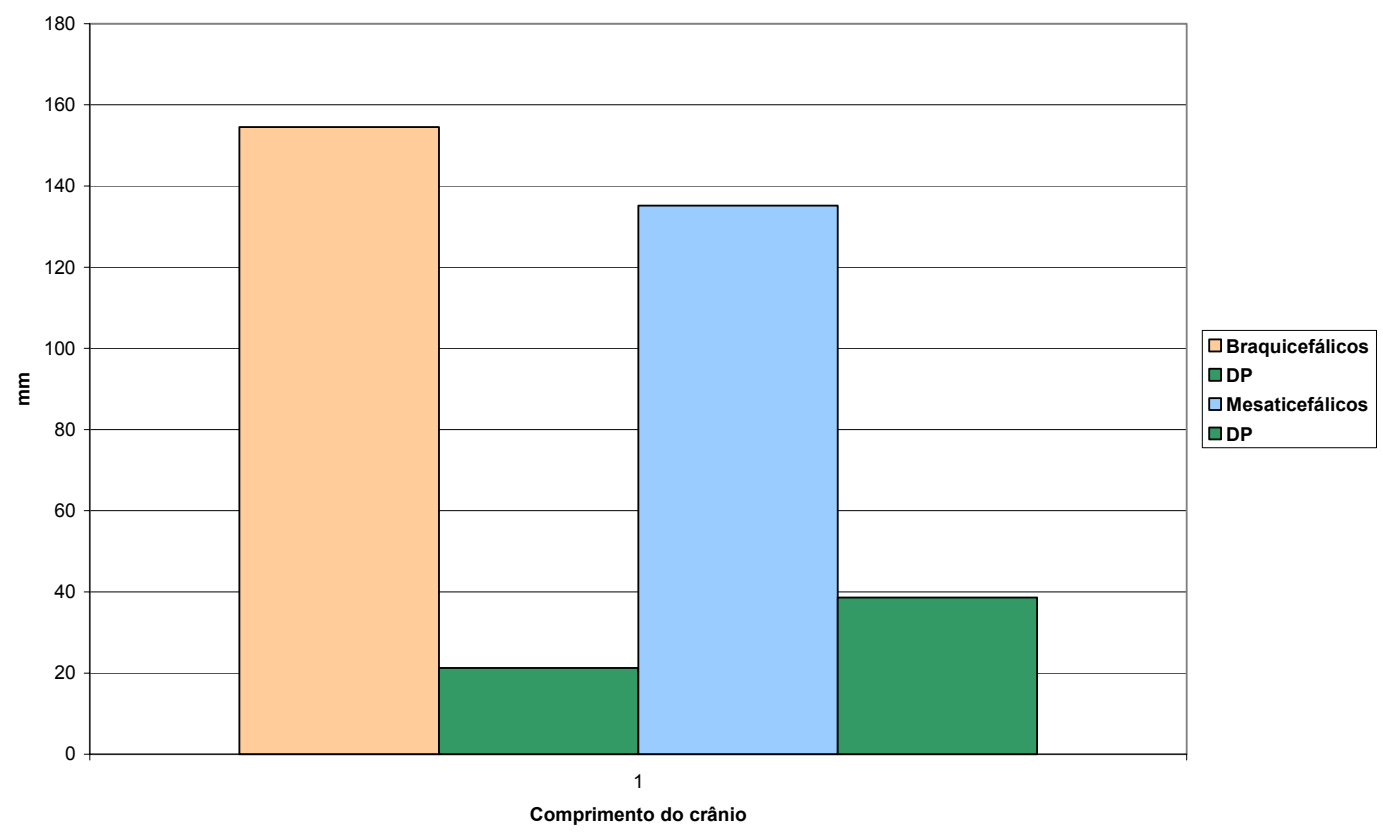

Figura 17 - $\quad$ Gráfico do comprimento do crânio $(\mathrm{mm})$ dos animais braquicefálicos e mesaticefálicos - São Paulo- 2006 


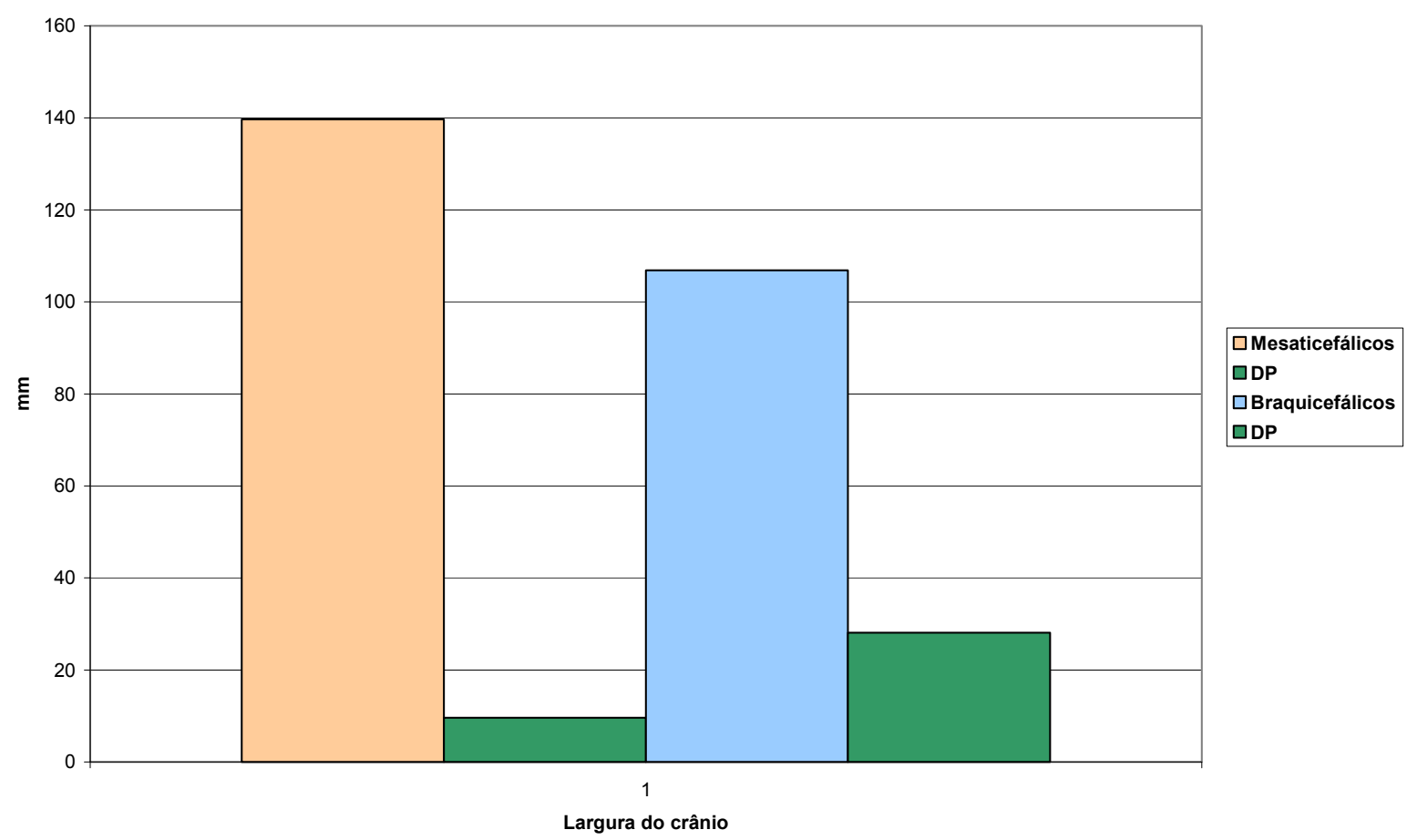

\begin{tabular}{|l|l}
\hline Figura 18 - & $\begin{array}{l}\text { Gráfico da largura do crânio }(\mathrm{mm}) \\
\text { mesaticefálicos - São Paulo - } 2006\end{array}$ \\
\hline
\end{tabular}

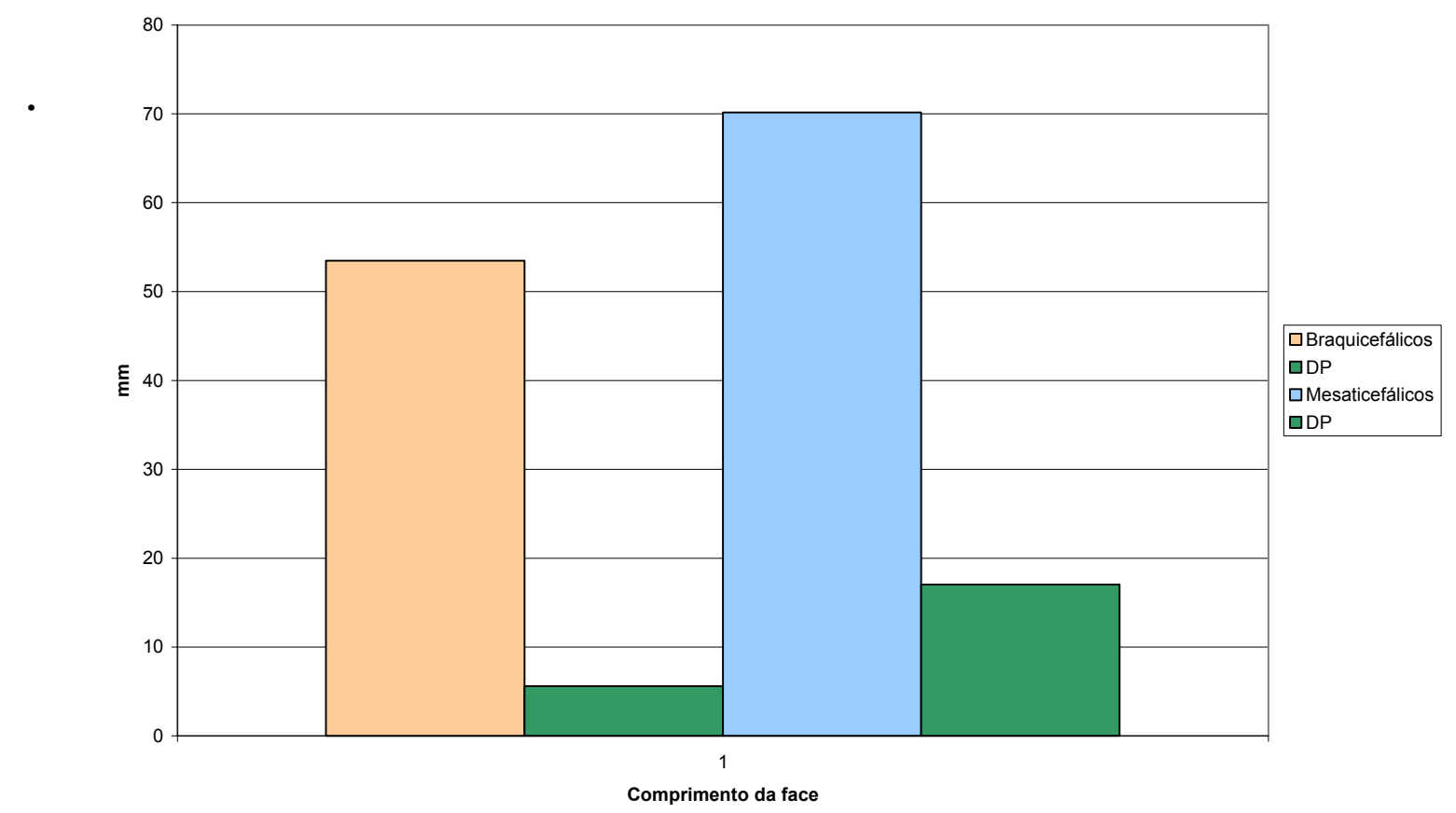

\begin{tabular}{|l|l}
\hline Figura 19 - & Gráfico do comprimento da face $(\mathrm{mm})$ dos animais braquicefálicos e
\end{tabular} mesaticefálicos - São Paulo - 2006 
Os resultados obtidos na mensuração do comprimento da face e crânio dos crânios mesaticefálicos e o ICF estão apresentados na tabela 3.

Tabela 3 - $\quad$ Medidas em mm do comprimento da face e do crânio e índice crânio facial (ICF) dos mesaticefálicos - São Paulo - 2006

\begin{tabular}{ccccc}
\hline No crânio & Raça & $\begin{array}{c}\text { Comprimento } \\
\text { da face }\end{array}$ & $\begin{array}{c}\text { Comprimento } \\
\text { do crânio }\end{array}$ & ICF \\
\hline 1 & SRD & 55,55 & 99,86 & 1,797 \\
2 & SRD & 91,94 & 145 & 1,577 \\
3 & Pinscher & 40,57 & 71,90 & 1,772 \\
4 & SRD & 64,26 & 146,26 & 2,276 \\
5 & SRD & 64,08 & 116,17 & 1,812 \\
6 & SRD & 80,04 & 139,69 & 1,745 \\
7 & Rotweiller & 82,91 & 194,01 & 2,340 \\
8 & Labrador & 81,86 & 168,7 & 2,060 \\
\hline Média & & $\mathbf{7 0 , 1 5 1}$ & $\mathbf{1 3 5 , 1 9 8}$ & $\mathbf{1 , 9 2 2}$ \\
Desvio padrão & & $\mathbf{1 7 , 0 3 8}$ & $\mathbf{3 8 , 6 1 4}$ & $\mathbf{0 , 2 7 2}$
\end{tabular}

Apresentados na tabela 3 os valores do comprimento da face e crânio dos animais mesaticefálicos em mm. O comprimento da face médio é de 70,151 $\pm 17,038$, o comprimento do crânio é o mesmo referido na tabela anterior e o ICF médio é $1,922 \pm 0,272$. Os animais são classificados como mesaticefálicos com o ICF com valores próximos a 2.

Os resultados obtidos na mensuração do comprimento da face e crânio dos crânios mesaticefálicos e o ICF estão apresentados na tabela 4 e no Apêndice D - Figuras 5 a 7.

\begin{tabular}{|l|l}
\hline Tabela 4 - & Medidas em mm do comprimento da face e do crânio e índice crânio facial
\end{tabular} (ICF) dos braquicefálicos - São Paulo - 2006

\begin{tabular}{ccccc}
\hline No crânio & Raça & $\begin{array}{c}\text { Comprimento } \\
\text { da face }\end{array}$ & $\begin{array}{c}\text { Comprimento } \\
\text { do crânio }\end{array}$ & ICF \\
\hline 1 & Boxer & 62,43 & 195,06 & 3,124 \\
2 & Boxer & 55,51 & 160,44 & 2,890 \\
3 & Boxer & 54,53 & 170,72 & 3,130 \\
4 & Boxer & 57,30 & 147,84 & 2,580 \\
5 & Boxer & 48,59 & 144,29 & 2,969 \\
6 & Boxer & 50,90 & 154,42 & 3,033 \\
7 & Boxer & 54,89 & 136,13 & 2,480 \\
8 & Boxer & 44,08 & 127,60 & 2,894 \\
\hline Média & & $\mathbf{5 3 , 4 6 6}$ & $\mathbf{1 5 4 , 5 6 2}$ & $\mathbf{2 , 8 9 0}$ \\
Desvio padrão & & $\mathbf{5 , 6 0 1}$ & $\mathbf{2 1 , 2 2 3}$ & $\mathbf{0 , 2 3 4}$
\end{tabular}


Os valores médios para o comprimento da face e o ICF são respectivamente: 53,466 \pm 5,601 e $2,890 \pm 0,234$. Nota-se para o comprimento da face, o valor inferior ao grupo mesaticefálico o que acarreta o ICF com valores próximos a 3, característico do grupo braquicefálico.

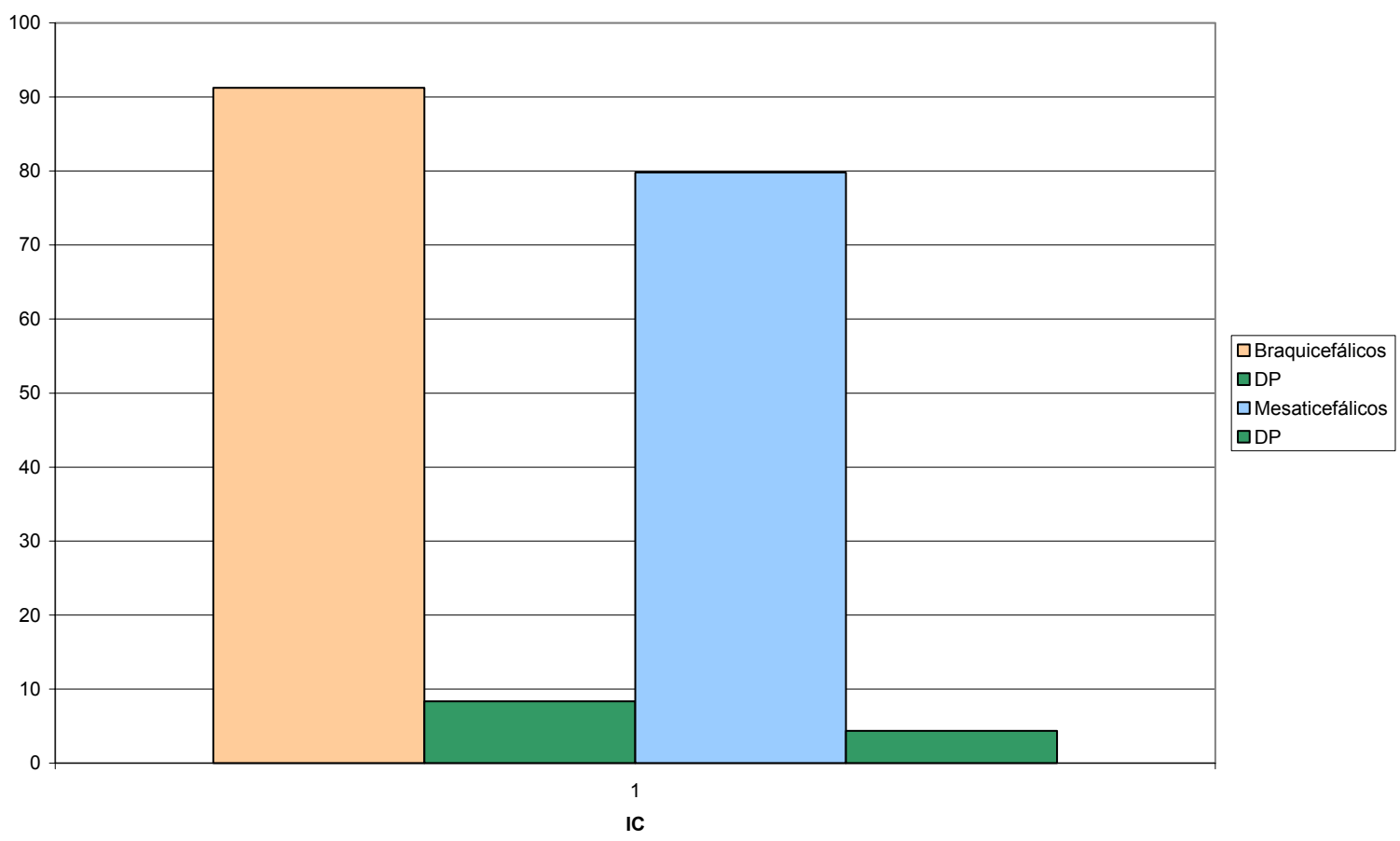

\begin{tabular}{|l|l|}
\hline Figura 20 - & Gráfico do IC dos animais braquicefálicos e mesaticefálicos - São Paulo - \\
\hline
\end{tabular} 2006

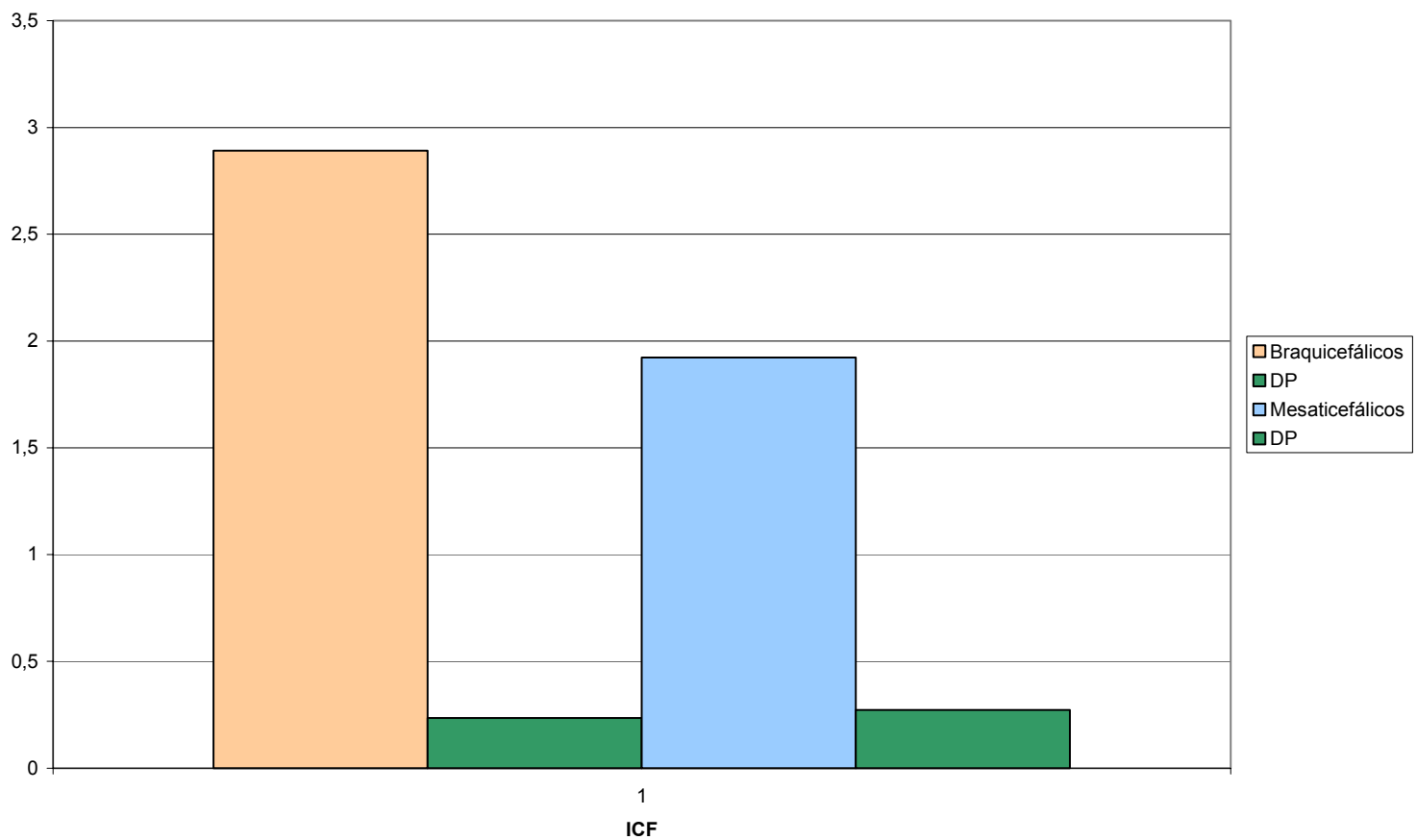




\subsection{ANÁLISE DA IMAGEM}

As imagens dos 16 crânios foram analisadas e mensuradas. O SVSD, que é a estrutura de interesse apresentou-se com contraste positivo na grande maioria das imagens. Com isso foi possível a mensuração da área e sua relação com estruturas ósseas da calota craniana. Consideramos como referência as estruturas ósseas comumente visualizadas em um exame tomográfico (Apêndices I, J, K e L).

As tabelas 5 a 20 apresentam os valores encontrados na análise pelo software e a seguir uma breve explicação comparativa entre os cortes do mesmo crânio.

Tabela 5 - $\quad$ Medidas da área $\left(\mathrm{mm}^{2}\right)$ e distâncias relativas do SVSD $(\mathrm{mm})$ à calota craniana do crânio B1 - São Paulo - 2006

\begin{tabular}{ccccccc}
\hline Cortes & $\begin{array}{c}\text { Area } \\
\text { SVSD } \\
(\mathbf{m m} \text { ) }\end{array}$ & $\begin{array}{c}\text { D1 } \\
\text { (perpendicular) }\end{array}$ & $\begin{array}{c}\text { D2 } \\
\text { (horizontal } \\
\text { esquerda) }\end{array}$ & $\begin{array}{c}\text { D3 } \\
\text { (horizontal } \\
\text { direita) }\end{array}$ & $\begin{array}{c}\text { D4 } \\
\text { (contorno } \\
\text { esquerda) }\end{array}$ & $\begin{array}{c}\text { D5 } \\
\text { (contorno } \\
\text { direita) }\end{array}$ \\
\hline $\mathbf{3}$ & 14,48 & 16,43 & 22,69 & 19,55 & 28,42 & 27,3 \\
$\mathbf{4}$ & 9,87 & 15,68 & 20,15 & 20,45 & 28,08 & 25,22 \\
$\mathbf{5}$ & 15,37 & 13,14 & 18,21 & 17,02 & 24,22 & 22,46 \\
$\mathbf{6}$ & 9,13 & 15,09 & 18,66 & 17,02 & 25,23 & 25,16 \\
$\mathbf{7}$ & 11,89 & 19,69 & 19,01 & 18,06 & 28,97 & 29,08 \\
\hline Média & $\mathbf{1 2 , 1 4 8}$ & $\mathbf{1 6 , 0 0 6}$ & $\mathbf{1 9 , 7 4 4}$ & $\mathbf{1 8 , 4 2}$ & $\mathbf{2 6 , 9 8 4}$ & $\mathbf{2 5 , 8 4 4}$ \\
DP & $\mathbf{1 , 8 3 1}$ & $\mathbf{2 , 3 0 5}$ & $\mathbf{2 , 6 0 2}$ & $\mathbf{1 , 0 5 3}$ & $\mathbf{0 , 3 8 8}$ & $\mathbf{1 , 2 5 8}$ \\
& & & & & &
\end{tabular}

A área média em $\mathrm{mm}^{2}$ é de $12,148 \pm 1,831$. A distância perpendicular média é de $16,006 \pm 2,305$. As distâncias horizontais esquerda e direitas têm como média 19,744 $\pm 2,602$ $\mathrm{mm}$ e $18,42 \pm 1,053 \mathrm{~mm}$ respectivamente. A média do contorno da calota é de $26,984 \pm 0,388$ mm para o lado esquerdo e $25,844 \pm 1,258 \mathrm{~mm}$ para o lado direito. 
O SVSD tem início no plano da porção média do arco zigomático (corte 3) e término na porção caudal da bula timpânica (corte 7). A maior área é considerada no corte 5, relacionado entre as articulações têmporo mandibulares (ATMs) e o arco zigomático. Em relação às distâncias, a menor medida do ápice da calota craniana até o ponto médio do SVSD é vista no corte 5 , o que está relacionado à maior área do vaso. No corte 7 , na união do SVSD e os seios transversos existe a maior distância perpendicular ao ápice da calota. Na porção inicial do crânio (cortes 3 e 4) estão as maiores relações horizontais do SVSD e as paredes laterais da calota craniana. Quanto a medida do contorno da calota, depara-se com menores valores no plano do corte 5 e os maiores valores no corte 7 .

\begin{tabular}{|c|c|c|c|c|c|c|}
\hline \multirow{2}{*}{$\begin{array}{l}\text { Tabela } 6 \text { - } \\
\text { Cortes }\end{array}$} & \multicolumn{6}{|c|}{$\begin{array}{l}\text { Medidas da área }\left(\mathrm{mm}^{2}\right) \text { e distâncias relativas do SVSD }(\mathrm{mm}) \text { à calota craniana } \\
\text { do crânio B2 - São Paulo - } 2006\end{array}$} \\
\hline & $\begin{array}{l}\text { Área } \\
\text { SVSD } \\
(\mathrm{mm} 2)\end{array}$ & $\begin{array}{c}\text { D1 } \\
\text { (perpendicular) }\end{array}$ & $\begin{array}{l}\text { D2 } \\
\text { (horizontal } \\
\text { esquerda) }\end{array}$ & $\begin{array}{l}\text { D3 } \\
\text { (horizontal } \\
\text { direita) }\end{array}$ & $\begin{array}{c}\text { D4 } \\
\text { (contorno } \\
\text { esquerda) }\end{array}$ & $\begin{array}{l}\text { D5 } \\
\text { (contorno } \\
\text { direita) }\end{array}$ \\
\hline 3 & 8,82 & 10,54 & 23,73 & 24,69 & 33,79 & 35,26 \\
\hline 4 & 21,09 & 10,68 & 20,61 & 21,26 & 29,23 & 29,02 \\
\hline 5 & 28,19 & 9,5 & 19,25 & 19,25 & 22,65 & 22,80 \\
\hline 6 & 17,83 & 11,6 & 18,22 & 18,22 & 25,54 & 26,21 \\
\hline 7 & 13,1 & 13,76 & 22,27 & 22,27 & 37,91 & 36,76 \\
\hline Média & 19,806 & 11,216 & 20,816 & 22,252 & 29,824 & 30,01 \\
\hline DP & 7,200 & 1,605 & 2,227 & 1,402 & 6,149 & 5,927 \\
\hline
\end{tabular}

No crânio B2, o SVSD têm início no corte número 3 que corresponde à porção média do arco zigomático e sua porção final pode ser visualizada ao nível do corte 7 , na região da bula timpânica.

A maior área do SVSD é vista no corte 5 relacionado à região das ATMs. Nesse corte evidencia-se a menor distância entre o ponto médio do SVSD e o ápice da calota craniana.

No corte 3 há a maior distância entre o ponto médio do SVSD e as calotas ósseas laterais direita e esquerda. 
A maior distância em relação às calotas laterais é visualizada no corte 6 .

Quanto à medida do contorno da calota, têm-se no corte 5 a menor distância e no corte 7 a maior em relação ao SVSD.

A área média em $\mathrm{mm}^{2}$ é de 19,806 $\pm 7,200$. A distância perpendicular média é de $11,216 \pm 1,605$. As distâncias horizontais esquerda e direita têm como média 20,816 $\pm 2,227$ $\mathrm{mm}$ e $22,252 \pm 1,402 \mathrm{~mm}$ respectivamente. A média do contorno da calota é de 29,824 \pm 6,149 $\mathrm{mm}$ para o lado esquerdo e 30,01 $\pm 5,927 \mathrm{~mm}$ para o lado direito.

\begin{tabular}{ccccccc}
\hline Tabela 7 - & \multicolumn{6}{l}{$\begin{array}{l}\text { Medidas da área }\left(\mathrm{mm}^{2}\right) \\
\text { do crânio B3 - distâncias relativas do SVSD }(\mathrm{mm}) \text { à calota craniana }\end{array}$} \\
\hline \multicolumn{7}{c}{ Saulo -2006} \\
\hline Cortes & $\begin{array}{c}\text { Área } \\
\text { SVSD } \\
\text { (mm2) }\end{array}$ & $\begin{array}{c}\text { D1 } \\
\text { (perpendicular) }\end{array}$ & $\begin{array}{c}\text { D2 } \\
\text { (horizontal } \\
\text { esquerda) }\end{array}$ & $\begin{array}{c}\text { D3 } \\
\text { (horizontal } \\
\text { direita) }\end{array}$ & $\begin{array}{c}\text { D4 } \\
\text { (contorno } \\
\text { esquerda) }\end{array}$ & $\begin{array}{c}\text { D5 } \\
\text { (contorno } \\
\text { direita) }\end{array}$ \\
\hline 3 & 6,54 & 8,43 & 12,57 & 14,98 & 19,19 & 17,82 \\
4 & 7,26 & 7,44 & 14,56 & 12,43 & 17,65 & 15,74 \\
5 & 7,89 & 12,56 & 22,85 & 19,06 & 23,98 & 20,88 \\
6 & 8,65 & 4,16 & 19,14 & 16,97 & 22,43 & 22,21 \\
7 & 5,88 & 10,99 & 19,31 & 12,83 & 25,07 & 22,03 \\
8 & 6,02 & 15,96 & 20,32 & 14,3 & 27,12 & 23,54 \\
\hline Média & $\mathbf{7 , 0 4}$ & $\mathbf{9 , 9 2 3}$ & $\mathbf{1 9 , 4 5 8}$ & $\mathbf{1 5 , 0 9 5}$ & $\mathbf{2 2 , 5 7 3}$ & $\mathbf{2 0 , 3 7}$ \\
DP & $\mathbf{1 , 0 9 5}$ & $\mathbf{4 , 1 5 0}$ & $\mathbf{2 , 7 4 2}$ & $\mathbf{2 , 5 3 4}$ & $\mathbf{3 , 5 9 4}$ & $\mathbf{2 , 9 7 9}$
\end{tabular}

Os valores médios encontrados para a área (mm2), D1,D2, D3, D4 e D5 foram respectivamente $7,04 \pm 1,095 ; 9,23 \pm 4,150 ; 19,458 \pm 2,742 ; 15,095 \pm 2,534 ; 22,573 \pm 3,594$; $20,37 \pm 2,979$.

O início do trajeto do SVSD corresponde à região da porção média do arco zigomático e término no osso occipital. A maior área do SVSD pode ser visualizada na região da ATM e também a menor distância D1 (perpendicular entre o ponto médio do SVSD e o ápice da calota craniana). No corte 8 (região occipital) é conferido a maior distância D1.

Na região cranial ao ramo horizontal da mandíbula, paralelo ao arco zigomático são encontrados os maiores valores para as distâncias em relação às extremidades laterais da 
calota craniana. Quanto ao contorno da calota craniana, a maior medida encontrada corresponde ao corte 8 .

\begin{tabular}{|c|cccccc|}
\hline Tabela 8 - & \multicolumn{5}{l}{$\begin{array}{l}\text { Medidas da área }\left(\mathrm{mm}^{2}\right) \\
\text { do crânio B4 }- \text { São Paulo }-2006\end{array}$} \\
\hline Cortes & $\begin{array}{c}\text { Area } \\
\text { SVSD } \\
\text { (mm2) }\end{array}$ & $\begin{array}{c}\text { D1 } \\
\text { (perpendicular) }\end{array}$ & $\begin{array}{c}\text { D2 } \\
\text { (horizontal } \\
\text { esquerda) }\end{array}$ & $\begin{array}{c}\text { D3 } \\
\text { (horizontal } \\
\text { direita) }\end{array}$ & $\begin{array}{c}\text { D4 } \\
\text { (contorno } \\
\text { esquerda) }\end{array}$ & $\begin{array}{c}\text { D5 } \\
\text { (contorno } \\
\text { direita) }\end{array}$ \\
\hline 5 & 3,35 & 10,55 & 24,42 & 22,46 & 27,79 & 22,36 \\
6 & 3,96 & 14,06 & 22,13 & 20,1 & 31,72 & 28,24 \\
7 & 2,75 & 15,24 & 23,61 & 19,54 & 32,84 & 23,67 \\
8 & 3,7 & 15,74 & 24,73 & 19,18 & 31,41 & 24,25 \\
9 & 4,16 & 16,4 & 23,8 & 19,67 & 30,94 & 23,72 \\
10 & 4,58 & 18,3 & 24,52 & 17,58 & 29,23 & 22,75 \\
\hline Média & $\mathbf{3 , 7 5}$ & $\mathbf{1 5 , 0 4 8}$ & $\mathbf{2 3 , 8 6 8}$ & $\mathbf{1 9 , 7 5 5}$ & $\mathbf{3 0 , 6 5 5}$ & $\mathbf{2 4 , 1 6 5}$ \\
DP & $\mathbf{0 , 6 4 2}$ & $\mathbf{2 , 6 1 2}$ & $\mathbf{0 , 9 5 5}$ & $\mathbf{1 , 5 8 4}$ & $\mathbf{1 , 8 3 2}$ & $\mathbf{2 , 1 1 2}$
\end{tabular}

A área média, em $\mathrm{mm}^{2}$ do SVSD foi de 3,75 \pm 0,642), em relação ao ápice da calota craniana o valor médio foi de $15,048 \pm 2,612 \mathrm{~mm}$ e em relação às extremidades laterais da calota 23,868 \pm 0,955 do lado esquerdo e 19,755 $\pm 1,584$ do lado esquerdo. Quanto aos valores do contorno da calota em relação ao ponto médio do SVSD, a média do lado esquerdo foi de $30,655 \pm 1,832$ e do lado direito $24,165 \pm 2,112 \mathrm{em} \mathrm{mm}$.

O trajeto do SVSD inicia-se no ponto médio do arco zigomático (corte 5) e termina na região caudal as bulas timpânicas e cranial ao osso occipital (corte 10). O maior valor da área mensurado foi na porção final do trajeto, já próximo à união com os seios transversos. A menor distância (D1) foi encontrada no início (corte 5) e a maior no final (corte 10). Os maiores valores de D2 e D3 são visualizados nos cortes 5 e 8 , e os menores nos cortes 6 e 10 . O contorno da calota apresentou simetria e mensuramos as maiores relações nos cortes 6 e 7 , enquanto as menores no corte 5. 


\begin{tabular}{|ccccccc|}
\hline Tabela 9 - & \multicolumn{6}{l}{$\begin{array}{l}\text { Medidas da área }\left(\mathrm{mm}^{2}\right) \\
\text { do crânio B5 - São Paulo }-2006\end{array}$} \\
\hline Cortes & $\begin{array}{c}\text { Área } \\
\text { SVSD } \\
\text { (mm })\end{array}$ & $\begin{array}{c}\text { D1 } \\
\text { (perpendicular) }\end{array}$ & $\begin{array}{c}\text { D2 } \\
\text { (horizontal } \\
\text { esquerda) }\end{array}$ & $\begin{array}{c}\text { D3 } \\
\text { (horizontal } \\
\text { direita) }\end{array}$ & $\begin{array}{c}\text { D4 } \\
\text { (contorno } \\
\text { esquerda) }\end{array}$ & $\begin{array}{c}\text { D5 } \\
\text { (contorno } \\
\text { direita) }\end{array}$ \\
\hline 4 & 8,46 & 9,75 & 22,3 & 22,92 & 28,78 & 27,74 \\
5 & 7,03 & 9,06 & 19,2 & 22,47 & 22,32 & 21,83 \\
6 & 10,6 & 8,07 & 16,79 & 15,95 & 21,3 & 19,48 \\
7 & 7,76 & 9,2 & 15,43 & 15,9 & 21,04 & 19,8 \\
8 & 8,46 & 10,2 & 12,92 & 14,74 & 17,17 & 17,32 \\
9 & 6,4 & 15,93 & 11,95 & 14,68 & 20,78 & 20,1 \\
\hline Média & $\mathbf{8 , 1 1 8}$ & $\mathbf{1 0 , 3 6 8}$ & $\mathbf{1 6 , 4 3 1}$ & $\mathbf{1 7 , 7 7 6}$ & $\mathbf{2 1 , 8 9 8}$ & $\mathbf{2 1 , 0 4 5}$ \\
DP & $\mathbf{1 , 4 5 9}$ & $\mathbf{2 , 8 1 7}$ & $\mathbf{3 , 8 8 9}$ & $\mathbf{3 , 8 5 0}$ & $\mathbf{3 , 8 0 0}$ & $\mathbf{3 , 5 8 3}$ \\
\hline
\end{tabular}

O crânio B5 possui o SVSD com início no corte 4 relacionando-se com o ponto médio do arco zigomático; e o término no corte 9, na região do osso occipital.

A maior área do SVSD e conseqüentemente menor distância entre o ápice da calota e o ponto médio do SVSD, pode ser vista no corte 6 , correspondente à região da ATM.

No que diz respeito às medidas horizontais entre o ponto médio do SVSD e as extremidades laterais da calota craniana, há simetria nos valores. A maior relação é vista no corte 4 e a menos no corte 9.

O contorno da calota apresenta maior medida no corte 4, região na qual visualizamos maior globosidade do crânio. O menor valor é visto no corte 9, na região do osso occipital e conseqüentemente estreitamento do crânio.

Os valores médios encontrados são: $8,118 \pm 1,459$ para área do SVSD em $\mathrm{mm}^{2}$, $10,368 \pm 2,817$ na distância perpendicular e $16,431 \pm 3,889$ e $17,776 \pm 3,850$ para medida horizontal esquerda e direita, em mm. As medidas dos contornos da calota em relação ao SVSD apresentam valores médios de $21,989 \pm 3,800$ do lado esquerdo e 21,045 $\pm 3,583$ do lado direito do crânio. 


\begin{tabular}{|ccccccc|}
\hline Tabela $10-$ & \multicolumn{5}{l}{$\begin{array}{l}\text { Medidas da área }\left(\mathrm{mm}^{2}\right) \\
\text { do crânio B6 - São Paulo }-2006\end{array}$} \\
\hline Cortes & $\begin{array}{c}\text { Area } \\
\text { SVSD } \\
\text { (mm2) }\end{array}$ & $\begin{array}{c}\text { D1 } \\
\text { (perpendicular) }\end{array}$ & $\begin{array}{c}\text { D2 } \\
\text { (horizontal } \\
\text { esquerda) }\end{array}$ & $\begin{array}{c}\text { D3 } \\
\text { (horizontal } \\
\text { direita) }\end{array}$ & $\begin{array}{c}\text { D4 } \\
\text { (contorno } \\
\text { esquerda) }\end{array}$ & $\begin{array}{c}\text { D5 } \\
\text { (contorno } \\
\text { direita) }\end{array}$ \\
\hline $\mathbf{3}$ & 9,27 & 14,27 & 30,75 & 22,77 & 43,74 & 42,67 \\
$\mathbf{4}$ & 16,25 & 16,31 & 19,52 & 22,02 & 37,73 & 34,8 \\
$\mathbf{5}$ & 15,02 & 14,1 & 18,47 & 19,53 & 44,39 & 40,67 \\
$\mathbf{6}$ & 14,27 & 15,37 & 17,57 & 19,1 & 23,86 & 25,31 \\
$\mathbf{7}$ & 5,05 & 15,65 & 15,66 & 16,47 & 22,72 & 20,98 \\
$\mathbf{8}$ & 12,54 & 26,66 & 18,53 & 19,32 & 23,07 & 23,41 \\
$\mathbf{9}$ & 6,8 & 25,66 & 14,46 & 14,09 & 30,41 & 29,76 \\
\hline Média & $\mathbf{1 1 , 3 1 4}$ & $\mathbf{1 8 , 1 4 5}$ & $\mathbf{1 9 , 2 8}$ & $\mathbf{1 9 , 0 4 2}$ & $\mathbf{3 2 , 2 7 4}$ & $\mathbf{3 1 , 0 8 5}$ \\
DP & $\mathbf{4 , 3 2 3}$ & $\mathbf{5 , 5 3 2}$ & $\mathbf{5 , 3 5 5}$ & $\mathbf{3 , 0 0 6}$ & $\mathbf{9 , 6 4 6}$ & $\mathbf{8 , 5 2 4}$ \\
\hline
\end{tabular}

O SVSD no crânio B6 têm início no corte 3 e término no corte 9, correspondendo respectivamente à porção média do arco zigomático e ao osso occipital. A maior área visualizada foi no corte 5 que representa a porção entre o final do osso zigomático e a articulação têmporo mandibular (ATM). Nesse corte encontramos a menor distância entre o ponto médio do SVSD e o ápice da calota craniana. A maior extensão horizontal é visualizada no corte 3, ou seja no início do SVSD, o qual ainda se encontra em pequeno calibre, conseqüentemente a menos extensão é vista no último corte (corte 9), pelo encontro com os seios transversos, na região occipital.

O contorno da calota craniana é menor ao nível do corte 7 (processo temporal do zigomático). A maior extensão encontrada não apresenta simetria sendo visualizada em dois cortes diferentes, corte 3 para o lado direito e corte 5 para o lado esquerdo.

Os valores médios encontrados são: $11,314 \pm$ 4,323 para área do SVSD em $\mathrm{mm}^{2}$, $18,145 \pm$ 5,532 na distância perpendicular e 19,28 \pm 5,355 e 19,042 \pm 3,006 para medida horizontal esquerda e direita, em mm. As medidas dos contornos da calota em relação ao SVSD apresentam valores médios de 32,274 \pm 9,646 do lado esquerdo e 31,085 \pm 8,524 do lado direito do crânio. 


\begin{tabular}{|c|c|c|c|c|c|c|}
\hline Tabela 11 & \multicolumn{6}{|c|}{$\begin{array}{l}\text { Medidas da área }\left(\mathrm{mm}^{2}\right) \text { e distâncias relativas do SVSD }(\mathrm{mm}) \text { à calota craniana } \\
\text { do crânio B7 - São Paulo - } 2006\end{array}$} \\
\hline Cortes & $\begin{array}{l}\text { Área } \\
\text { SVSD } \\
(\mathrm{mm} 2) \\
\end{array}$ & $\begin{array}{c}\text { D1 } \\
\text { (perpendicular) }\end{array}$ & $\begin{array}{c}\text { D2 } \\
\text { (horizontal } \\
\text { esquerda) }\end{array}$ & $\begin{array}{c}\text { D3 } \\
\text { (horizontal } \\
\text { direita) }\end{array}$ & $\begin{array}{c}D 4 \\
\text { (contorno } \\
\text { esquerda) }\end{array}$ & $\begin{array}{c}\text { D5 } \\
\text { (contorno } \\
\text { direita) } \\
\end{array}$ \\
\hline 4 & 8,86 & 12,01 & 22,84 & 26,52 & 36,26 & 35,2 \\
\hline 5 & 11,39 & 12,68 & 22,24 & 19,36 & 30,02 & 28,31 \\
\hline 6 & 11,64 & 11,08 & 17,74 & 17,61 & 32,84 & 30,07 \\
\hline 7 & 10,33 & 12,28 & 17,5 & 16,5 & 22,45 & 22,55 \\
\hline 8 & 6,75 & 12,42 & 15,6 & 14,29 & 19,94 & 19,15 \\
\hline Média & 9,794 & 12,094 & 19,184 & 18,856 & 28,302 & 27,056 \\
\hline DP & 2,023 & 0,616 & 3,180 & 4,662 & 6,910 & 6,320 \\
\hline
\end{tabular}

No crânio B7, o SVSD inicia-se no corte 4 e termina no corte 8, correspondendo respectivamente à porção média do arco zigomático e ao osso occipital. A maior área visualizada foi no corte 6 na região da articulação têmporo mandibular (ATM). Nesse corte encontramos a menor distância entre o ponto médio do SVSD e o ápice da calota craniana. A maior extensão horizontal é visualizada no corte 4, no início do SVSD, o qual ainda se encontra em pequeno calibre, conseqüentemente a menor extensão é vista no último corte (corte 8), pelo encontro com os seios transversos, na região occipital.

O contorno da calota craniana é menor ao nível do corte 8 (região do osso occipital). A maior extensão encontrada é visualizada no corte 4, no inicio do trajeto do SVSD, na região do arco zigomático.

Os valores médios encontrados são: 9,794 $\pm 2,023$ para área do SVSD em mm², $12,094 \pm$ 0,616 na distância perpendicular e 19,184 $\pm 3,180$ e 18,856 \pm 4,662 para medida horizontal esquerda e direita, em mm. As medidas dos contornos da calota em relação ao SVSD apresentam valores médios de $28,302 \pm 6,910$ do lado esquerdo e 27,056 $\pm 6,320$ do lado direito do crânio. 


\begin{tabular}{|c|c|c|c|c|c|c|}
\hline Tabela 12 & \multicolumn{6}{|c|}{$\begin{array}{l}\text { Medidas da área }\left(\mathrm{mm}^{2}\right) \text { e distâncias relativas do SVSD }(\mathrm{mm}) \text { à calota craniana } \\
\text { do crânio B8 - São Paulo - } 2006\end{array}$} \\
\hline Cortes & $\begin{array}{l}\text { Área } \\
\text { SVSD } \\
\text { (mm2) }\end{array}$ & $\begin{array}{c}\text { D1 } \\
\text { (perpendicular) }\end{array}$ & $\begin{array}{c}\text { D2 } \\
\text { (horizontal } \\
\text { esquerda) }\end{array}$ & $\begin{array}{c}D 3 \\
\text { (horizontal } \\
\text { direita) }\end{array}$ & $\begin{array}{c}D 4 \\
\text { (contorno } \\
\text { esquerda) }\end{array}$ & $\begin{array}{c}\text { D5 } \\
\text { (contorno } \\
\text { direita) }\end{array}$ \\
\hline 4 & 5,89 & 9,03 & 16,91 & 17,03 & 21,09 & 20,04 \\
\hline 5 & 7,52 & 9,37 & 17,56 & 15,38 & 18,98 & 19,92 \\
\hline 6 & 12,72 & 7,76 & 15,22 & 12,73 & 16,09 & 16,81 \\
\hline 7 & 8,48 & 10,4 & 13,91 & 13,2 & 16,51 & 17,72 \\
\hline 8 & 13,01 & 13,21 & 11,83 & 13,53 & 18,61 & 18,59 \\
\hline Média & 9,45 & 11,12 & 14,37 & 15,28 & 19,85 & 19,315 \\
\hline DP & 3,188 & 2,049 & 2,315 & 1,793 & 2,026 & 1,395 \\
\hline
\end{tabular}

Foram encontrados os seguintes valores médios: 9,45 \pm 3,188 para área do SVSD em $\mathrm{mm}^{2}, 11,12 \pm 2,049$ na distância perpendicular e $14,37 \pm 2,315$ e 15,28 $\pm 1,793$ para medida horizontal esquerda e direita, em mm. As medidas dos contornos da calota em relação ao SVSD apresentam valores médios de 19,85 \pm 2,026 do lado esquerdo e 19,315 \pm 1,395 do lado direito do crânio.

O SVSD tem início no ponto médio do arco zigomático (corte 4) e término na região do osso occipital (corte 8). Em relação à área do SVSD, o maior valor é visto no corte 8 , onde o SVSD afasta-se da calota craniana, isto é a maior distância perpendicular do ponto seu ponto médio ápice da calota, para unir-se com os seios transversos direito e esquerdo. $\mathrm{O}$ menos valor é visualizado no início do trajeto do seio (corte 4).

As medidas relacionadas ás extremidades laterais da calota craniana possuem maior valor ao nível dos corte 4 e 5 e menor valor nos corte 6 e 8 . O maior contorno da calota craniana foi mensurado no corte 4 , onde há uma irregularidade na calota que apresenta o seu ápice convexo e as laterais mais côncavas. 


\begin{tabular}{|c|cccccc|}
\hline Tabela 13 - & \multicolumn{5}{l}{$\begin{array}{l}\text { Medidas da área }\left(\mathrm{mm}^{2}\right) \\
\text { do crânio } \mathrm{M} 1-\mathrm{S} \text { e distâncias Paulo }-2006\end{array}$} \\
\hline Cortes & $\begin{array}{c}\text { Área } \\
\text { SVSD } \\
\text { (mm2) }\end{array}$ & $\begin{array}{c}\text { D1 } \\
\text { (perpendicular) }\end{array}$ & $\begin{array}{c}\mathbf{D 2} \\
\text { (horizontal } \\
\text { esquerda) }\end{array}$ & $\begin{array}{c}\text { D3 } \\
\text { (horizontal } \\
\text { direita) }\end{array}$ & $\begin{array}{c}\text { D4 } \\
\text { (contorno } \\
\text { esquerda) }\end{array}$ & $\begin{array}{c}\text { D5 } \\
\text { (contorno } \\
\text { direita) }\end{array}$ \\
\hline $\mathbf{4}$ & 10,26 & 7,62 & 17,67 & 15,13 & 20,77 & 18,8 \\
$\mathbf{5}$ & 9,43 & 4,88 & 17,6 & 15,1 & 15,63 & 12,69 \\
$\mathbf{6}$ & 13,31 & 4,65 & 16,22 & 12,43 & 15,84 & 14,04 \\
$\mathbf{7}$ & 16,2 & 5,79 & 17,57 & 13,12 & 17,32 & 13,34 \\
\hline Média & $\mathbf{1 2 , 3}$ & $\mathbf{5 , 7 3 5}$ & $\mathbf{1 7 , 2 6 5}$ & $\mathbf{1 3 , 9 4 5}$ & $\mathbf{1 7 , 3 9}$ & $\mathbf{1 4 , 7 1 7}$ \\
DP & $\mathbf{3 , 0 8 9}$ & $\mathbf{1 , 3 4 9}$ & $\mathbf{0 , 6 9 7}$ & $\mathbf{1 , 3 8 0}$ & $\mathbf{2 , 3 7 5}$ & $\mathbf{2 , 7 7 6}$ \\
\end{tabular}

O crânio M1 possui o SVSD com início no corte 4 relacionando-se com o ponto médio do arco zigomático; e o término no corte 7, na região das bulas timpânicas.

A maior área do SVSD pode ser vista no corte 7, na porção final do trajeto do seio. A menor distância (D1) está localizada no corte 6, na região da ATM. No que diz respeito às medidas horizontais entre o ponto médio do SVSD e as extremidades laterais da calota craniana, há simetricidade nos valores. A maior relação é vista no corte 4 e a menor no corte 6.

O contorno da calota apresenta maior medida no corte 4, porção inicial do SVSD. O menor valor é visto no corte 5, na porção final do arco zigomático.

Os valores médios encontrados são: $12,3 \pm 3,089$ para área do SVSD em mm² $, 5,735 \pm$ 1,349 na distância perpendicular e 17,265 \pm 0,697 e 13,945 \pm 1,380 para medida horizontal esquerda e direita, em mm. As medidas dos contornos da calota em relação ao SVSD apresentam valores médios de $17,39 \pm 2,375$ do lado esquerdo e 14,717 $\pm 2,776$ do lado direito do crânio. 


\begin{tabular}{|c|c|c|c|c|c|c|}
\hline Tabela 1 & $\begin{array}{l}\text { Mec } \\
\text { do c }\end{array}$ & $\begin{array}{l}\text { Idas da área }\left(\mathrm{mm}^{2}\right. \\
\text { ânio } \mathrm{M} 2 \text { - São Pa }\end{array}$ & $\begin{array}{l}\text { e distâncias } \\
\text { lo }-2006\end{array}$ & tivas do SV & $(\mathrm{mm})$ à cc & ota craniana \\
\hline Cortes & $\begin{array}{l}\text { Área } \\
\text { SVSD } \\
(\mathrm{mm} 2) \\
\end{array}$ & $\begin{array}{c}D 1 \\
\text { (perpendicular) }\end{array}$ & $\begin{array}{c}\text { D2 } \\
\text { (horizontal } \\
\text { esquerda) }\end{array}$ & $\begin{array}{c}\text { D3 } \\
\text { (horizontal } \\
\text { direita) }\end{array}$ & $\begin{array}{c}D 4 \\
\text { (contorno } \\
\text { esquerda) }\end{array}$ & $\begin{array}{c}\text { D5 } \\
\text { (contorno } \\
\text { direita) } \\
\end{array}$ \\
\hline 9 & 7,59 & 8,32 & 12,6 & 12,54 & 15,67 & 15,88 \\
\hline 10 & 7,94 & 8,18 & 13 & 12,65 & 14,98 & 15,36 \\
\hline 11 & 7,98 & 7,65 & 13,26 & 13,07 & 16,57 & 16,41 \\
\hline 12 & 8,05 & 6,45 & 13,56 & 13,34 & 15,16 & 14,56 \\
\hline 13 & 8,49 & 5,58 & 13,26 & 11,63 & 13,57 & 14,84 \\
\hline 14 & 9,73 & 7,11 & 14 & 11,78 & 14,7 & 14,77 \\
\hline 15 & 16,39 & 10 & 14,65 & 13,72 & 17,34 & 17,07 \\
\hline Média & 9,452 & 7,612 & 13,475 & 12,675 & 15,427 & 15,555 \\
\hline DP & 3,136 & 1,429 & 0,676 & 0,774 & 1,243 & 0,938 \\
\hline
\end{tabular}

Foram encontrados os seguintes valores médios: 9,452 $\pm 3,136$ para área do SVSD em $\mathrm{mm}^{2}, 7,612 \pm 1,429$ na distância perpendicular e 13,475 $\pm 0,676$ e $12,675 \pm 0,774$ para medida horizontal esquerda e direita, em $\mathrm{mm}$. As medidas dos contornos da calota em relação ao SVSD apresentam valores médios de $15,427 \pm 1,243$ do lado esquerdo e 15,555 \pm 0,938 do lado direito do crânio.

O SVSD tem início no processo temporal do arco zigomático (corte 9) e término na região do osso occipital (corte 15). Em relação à área do SVSD, o maior valor é visto no corte 15, onde o SVSD afasta-se da calota craniana, isto é a maior distância perpendicular do ponto seu ponto médio ápice da calota, para unir-se com os seios transversos direito e esquerdo. $\mathrm{O}$ menos valor é visualizado no início do trajeto do seio (corte 9).

As medidas relacionadas ás extremidades laterais da calota craniana possuem maior valor ao nível do corte 15 e menor valor nos cortes 12 e 13 . O maior contorno da calota craniana foi mensurado no corte 15 , onde há a crista sagital externa proeminente. 


\begin{tabular}{|c|c|c|c|c|c|c|}
\hline \multicolumn{2}{|c|}{ Tabela 15 - } & \multicolumn{5}{|c|}{$\begin{array}{l}\text { Medidas da área }\left(\mathrm{mm}^{2}\right) \text { e distâncias relativas do SVSD }(\mathrm{mm}) \text { à calota craniana } \\
\text { do crânio M3 - São Paulo - } 2006\end{array}$} \\
\hline Cortes & $\begin{array}{l}\text { Área } \\
\text { SVSD } \\
\text { (mm2) }\end{array}$ & $\begin{array}{c}\text { D1 } \\
\text { (perpendicular) }\end{array}$ & $\begin{array}{c}\text { D2 } \\
\text { (horizontal } \\
\text { esquerda) }\end{array}$ & $\begin{array}{c}D 3 \\
\text { (horizontal } \\
\text { direita) }\end{array}$ & $\begin{array}{c}D 4 \\
\text { (contorno } \\
\text { esquerda) }\end{array}$ & $\begin{array}{c}\text { D5 } \\
\text { (contorno } \\
\text { direita) }\end{array}$ \\
\hline 5 & 4,61 & 3,47 & 28,09 & 21,73 & 28,44 & 29,67 \\
\hline 6 & 7,19 & 4,4 & 24,11 & 28,65 & 29,44 & 29,36 \\
\hline 7 & 8,51 & 4,82 & 21,14 & 28,66 & 27,36 & 27,77 \\
\hline 8 & 8,83 & 3,01 & 25,96 & 27,09 & 23,36 & 27,76 \\
\hline 9 & 6,7 & 3,97 & 22,62 & 22,75 & 26,43 & 27,05 \\
\hline Média & 7,168 & 3,934 & 24,384 & 25,776 & 27,12 & 28,322 \\
\hline DP & 1,682 & 0,719 & 2,735 & 3,310 & 2,366 & 1,132 \\
\hline
\end{tabular}

O SVSD no crânio M3 têm início no corte 5 e término no corte 9, correspondendo respectivamente à porção média do arco zigomático e a região das bulas timpânicas. A maior área visualizada foi no corte 8 que representa a região da ATM. Nesse corte encontramos a menor distância entre o ponto médio do SVSD e o ápice da calota craniana. A maior extensão horizontal é visualizada no corte 5 e 7; a menos extensão é vista nos cortes 5 e 7 , determinado uma relação simétrica.

O contorno da calota craniana é maior ao nível dos cortes 5 e 6 (arco zigomático). A maior extensão é visualizada nas porções finais do SVSD, nos cortes 8 e 9 .

Os valores médios encontrados são: 7,168 \pm 1,682 para área do SVSD em mm², 3,934 \pm 0,719 na distância perpendicular e 24,384 $\pm 2,735$ e 25,776 \pm 3,310 para medida horizontal esquerda e direita, em mm. As medidas dos contornos da calota em relação ao SVSD apresentam valores médios de 27,12 $\pm 2,366$ do lado esquerdo e 28,322 \pm 1,132 do lado direito do crânio. 


\begin{tabular}{|ccccccc|}
\hline Tabela $16-$ & \multicolumn{5}{l}{$\begin{array}{l}\text { Medidas da área }\left(\mathrm{mm}^{2}\right) \\
\text { do crânio } \text { M4 } \text { - São Paulo }-2006\end{array}$} \\
\hline Cortes & $\begin{array}{c}\text { Área } \\
\text { SVSD } \\
\text { (mm2) }\end{array}$ & $\begin{array}{c}\text { D1 } \\
\text { (perpendicular) }\end{array}$ & $\begin{array}{c}\text { D2 } \\
\text { (horizontal } \\
\text { esquerda) }\end{array}$ & $\begin{array}{c}\text { D3 } \\
\text { (horizontal } \\
\text { direita) }\end{array}$ & $\begin{array}{c}\text { D4 } \\
\text { (contorno } \\
\text { esquerda) }\end{array}$ & $\begin{array}{c}\text { D5 } \\
\text { (contorno } \\
\text { direita) }\end{array}$ \\
\hline $\mathbf{6}$ & 2,59 & 4,47 & 12,05 & 10,93 & 11,89 & 12,44 \\
7 & 3,36 & 4,23 & 9,94 & 8,07 & 11,98 & 11,29 \\
$\mathbf{8}$ & 3,47 & 4,98 & 11,56 & 8,2 & 11,07 & 10,92 \\
$\mathbf{9}$ & 4,1 & 6,32 & 11,84 & 8,39 & 13,49 & 14,18 \\
$\mathbf{1 0}$ & 4,32 & 7,86 & 10,06 & 7,49 & 10,58 & 10,67 \\
$\mathbf{1 1}$ & 13 & 9,08 & 8,59 & 7,37 & 10,77 & 12,49 \\
\hline Média & $\mathbf{5 , 1 4}$ & $\mathbf{6 , 1 5 6}$ & $\mathbf{1 0 , 6 7 8}$ & $\mathbf{8 , 4 0 8}$ & $\mathbf{1 1 , 6 3}$ & $\mathbf{1 1 , 9 9 8}$ \\
DP & $\mathbf{3 , 8 9 8}$ & $\mathbf{1 , 9 7 0}$ & $\mathbf{1 , 3 6 8}$ & $\mathbf{1 , 2 9 9}$ & $\mathbf{1 , 0 7 7}$ & $\mathbf{1 , 3 1 2}$ \\
\hline
\end{tabular}

O crânio M4 possui o SVSD com início no corte 6 relacionando-se com o ponto médio do arco zigomático; e o término no corte 11, na região caudal ás bulas timpânicas.

A maior área do SVSD pode ser vista no corte 8, na região da ATM. A menor distância (D1) está localizada no corte 7, na região cranial á ATM. Relacionado às medidas horizontais entre o ponto médio do SVSD e as extremidades laterais da calota craniana, a maior relação é vista no corte 6 e a menor nos cortes: 9 (lado direito) e 11 (lado esquerdo).

O contorno da calota apresenta maior medida no corte 11, porção final do SVSD. O menor valor é visto no corte 8 , na região da ATM.

Os valores médios encontrados são: 5,14 $\pm 3,898$ para área do SVSD em mm² $, 6,156 \pm$ 1,970 na distância perpendicular e 10,678 $\pm 1,368$ e 8,408 $\pm 1,299$ para medida horizontal esquerda e direita, em mm. As medidas dos contornos da calota em relação ao SVSD apresentam valores médios de 11,63 \pm 1,077 do lado esquerdo e 11,998 \pm 1,312 do lado direito do crânio 


\begin{tabular}{|c|c|c|c|c|c|c|}
\hline \multirow{2}{*}{$\begin{array}{l}\text { Tabela } 17 \\
\text { Cortes }\end{array}$} & \multicolumn{6}{|c|}{$\begin{array}{l}\text { Medidas da área }\left(\mathrm{mm}^{2}\right) \text { e distâncias relativas do SVSD }(\mathrm{mm}) \text { à calota craniana } \\
\text { do crânio M5 - São Paulo - } 2006\end{array}$} \\
\hline & $\begin{array}{l}\text { Área } \\
\text { SVSD } \\
(\mathrm{mm} 2)\end{array}$ & $\begin{array}{c}D 1 \\
\text { (perpendicular) }\end{array}$ & $\begin{array}{c}\text { D2 } \\
\text { (horizontal } \\
\text { esquerda) }\end{array}$ & $\begin{array}{c}D 3 \\
\text { (horizontal } \\
\text { direita) }\end{array}$ & $\begin{array}{c}\text { D4 } \\
\text { (contorno } \\
\text { esquerda) }\end{array}$ & $\begin{array}{c}\text { D5 } \\
\text { (contorno } \\
\text { direita) }\end{array}$ \\
\hline 7 & 3,65 & 6,99 & 15,92 & 14,57 & 18,3 & 16,9 \\
\hline 8 & 9,02 & 6,91 & 15,06 & 14,2 & 18,06 & 15,39 \\
\hline 9 & 12,13 & 6,17 & 14,44 & 14,32 & 15,32 & 14,53 \\
\hline 10 & 7,92 & 6,29 & 13,84 & 14,77 & 15,11 & 14,31 \\
\hline 11 & 8,06 & 5,87 & 14,48 & 15,46 & 16,64 & 14,82 \\
\hline 12 & 6,18 & 7,57 & 15,12 & 15,7 & 16,9 & 16,12 \\
\hline 13 & 6,13 & 8,27 & 15,8 & 14,82 & 18,22 & 16,32 \\
\hline Média & 7,584 & 6,867 & 14,951 & 14,834 & 16,935 & 15,484 \\
\hline DP & 2,665 & 0,845 & 0,754 & 0,56 & 1,342 & 0,987 \\
\hline
\end{tabular}

O crânio M5 possui o SVSD com início no corte 7 relacionando-se com o processo temporal do arco zigomático; e o término no corte 13, na região das bulas timpânicas.

A maior área do SVSD pode ser vista no corte 9 (região das ATMs) e a menor área no início do trajeto no corte 7. A menor distância entre o ápice da calota e o ponto médio do SVSD, pode ser vista no corte 11, correspondente à região cranial ás bulas timpânicas.

No que diz respeito às medidas horizontais entre o ponto médio do SVSD e as extremidades laterais da calota craniana, não há simetricidade nos valores As maiores distâncias são visualizadas nos cortes 7 e 11, e as menores nos cortes 8 e 10 .

O contorno da calota apresenta maior medida no corte 7 , região inicial do SVSD e menor valor no corte 10, na região das ATMs.

Os valores médios encontrados são: 7,584 $\pm 2,665$ para área do SVSD em mm² $, 6,867$ $\pm 0,845$ na distância perpendicular e $14,951 \pm 0,754$ e $14,834 \pm 0,56$ para medida horizontal esquerda e direita, em mm. As medidas dos contornos da calota em relação ao SVSD apresentam valores médios de 16,935 $\pm 1,342$ do lado esquerdo e 15,484 \pm 0,987 do lado direito do crânio. 


\begin{tabular}{|c|c|c|c|c|c|c|}
\hline \multirow{2}{*}{$\begin{array}{l}\text { Tabela } 1 \\
\text { Cortes }\end{array}$} & \multicolumn{6}{|c|}{$\begin{array}{l}\text { Medidas da área }\left(\mathrm{mm}^{2}\right) \text { e distâncias relativas do SVSD }(\mathrm{mm}) \text { à calota craniana } \\
\text { do crânio M6 - São Paulo - } 2006\end{array}$} \\
\hline & $\begin{array}{c}\text { Área } \\
\text { SVSD } \\
(\mathrm{mm} 2) \\
\end{array}$ & $\begin{array}{c}\text { D1 } \\
\text { (perpendicular) }\end{array}$ & $\begin{array}{c}\text { D2 } \\
\text { (horizontal } \\
\text { esquerda) }\end{array}$ & $\begin{array}{c}\text { D3 } \\
\text { (horizontal } \\
\text { direita) }\end{array}$ & $\begin{array}{c}\text { D4 } \\
\text { (contorno } \\
\text { esquerda) }\end{array}$ & $\begin{array}{c}D 5 \\
\text { (contorno } \\
\text { direita) }\end{array}$ \\
\hline 4 & 3,52 & 3,01 & 18,94 & 17,29 & 20,95 & 20 \\
\hline 5 & 6,55 & 8,63 & 16,51 & 17,16 & 19,09 & 21,36 \\
\hline 6 & 5,64 & 8,7 & 15,71 & 19,33 & 17,06 & 20,28 \\
\hline 7 & 4,92 & 6,04 & 14,34 & 17,37 & 16,69 & 18,37 \\
\hline 8 & 10,26 & 7,87 & 16,42 & 17,8 & 19,28 & 19,35 \\
\hline Média & 6,178 & 6,85 & 16,384 & 17,79 & 18,614 & 19,872 \\
\hline DP & 2,536 & 2,399 & 1,672 & 0,893 & 1,749 & 1,109 \\
\hline
\end{tabular}

A área média, em $\mathrm{mm}^{2}$ do SVSD foi de $6,478 \pm 2,536$ ), em relação ao ápice da calota craniana o valor médio foi de $6,85 \pm 2,399 \mathrm{~mm}$ e em relação às extremidades laterais da calota $17,79 \pm 0,893$ do lado direito e 16,384 \pm 1,672 do lado esquerdo. Quanto aos valores do contorno da calota em relação ao ponto médio do SVSD, a média do lado esquerdo foi de $18,614 \pm 1,749$ e do lado direito $19,872 \pm 1,109 \mathrm{em} \mathrm{mm}$.

O trajeto do SVSD inicia-se no ponto médio do arco zigomático (corte 4) e termina na região caudal as bulas timpânicas e cranial ao osso occipital (corte 8). O maior valor da área mensurado foi na porção final do trajeto, já próximo à união com os seios transversos. A menor distância (D1) foi encontrada no início (corte 4) e a maior na região da ATM (corte 6). Os maiores valores de D2 e D3 são visualizados nos cortes 4 e 6, e os menores nos cortes 5 e 7. O contorno da calota tem os maiores valores nos cortes iniciais (4 e 5) relacionados ao arco zigomático e os menores valores na porção média do SVSD (cortes 6 e 7 


\begin{tabular}{|c|c|c|c|c|c|c|}
\hline Tabela 19 & \multicolumn{6}{|c|}{$\begin{array}{l}\text { Medidas da área }\left(\mathrm{mm}^{2}\right) \text { e distâncias relativas do SVSD }(\mathrm{mm}) \text { à calota craniana } \\
\text { do crânio M7 - São Paulo - } 2006\end{array}$} \\
\hline Cortes & $\begin{array}{l}\text { Área } \\
\text { SVSD } \\
\text { (mm2) }\end{array}$ & $\begin{array}{c}\text { D1 } \\
\text { (perpendicular) }\end{array}$ & $\begin{array}{c}\text { D2 } \\
\text { (horizontal } \\
\text { esquerda) }\end{array}$ & $\begin{array}{c}D 3 \\
\text { (horizontal } \\
\text { direita) }\end{array}$ & $\begin{array}{c}D 4 \\
\text { (contorno } \\
\text { esquerda) }\end{array}$ & $\begin{array}{c}\text { D5 } \\
\text { (contorno } \\
\text { direita) }\end{array}$ \\
\hline 3 & 6,2 & 11,78 & 19,62 & 21,05 & 27,59 & 25,85 \\
\hline 4 & 6,28 & 12,49 & 21,92 & 19,92 & 23,76 & 23,45 \\
\hline 5 & 5,98 & 5,61 & 16,56 & 18,34 & 25,26 & 22,26 \\
\hline 6 & 5,06 & 4,97 & 15,92 & 17,71 & 19,01 & 22,1 \\
\hline 7 & 8,94 & 22,23 & 17,48 & 15,05 & 29,64 & 31,65 \\
\hline Média & 6,492 & 11,416 & 18,3 & 18,414 & 25,052 & 25,062 \\
\hline DP & 1,452 & 6,955 & 2,460 & 2,293 & 4,053 & 3,976 \\
\hline
\end{tabular}

No crânio M7, o SVSD têm início no corte número 3 que corresponde à porção média do osso zigomático e sua porção final pode ser visualizada ao nível do corte 7 , na região caudal das bulas timpânicas.

A maior área do SVSD é vista no corte 7 relacionado à região final do trajeto do SVSD. Nesse corte evidencia-se a crista sagital externa muito protuberante e consequentemente a maior distancia entre o ponto médio do SVSD e o ápice da calota craniana.

Nos cortes 3 e 4 há a maior distância entre o ponto médio do SVSD e as calotas ósseas laterais direita e esquerda. A menor distância em relação às calotas laterais é visualizada nos cortes 6 e 7 .

Quanto ao medida do contorno da calota, têm-se no corte 6 (região da ATM) a menor distância e no corte 7, a maior em relação ao SVSD.

A área média, em $\mathrm{mm}^{2}$ é de $6,492 \pm 1,452$. A distância perpendicular média é de $11,416 \pm 6,955)$. As distancia horizontais esquerda e direita têm como média $18,3 \pm 2,460$ $\mathrm{mm}$ e $18,414 \pm 2,293 \mathrm{~mm}$ respectivamente. A média do contorno da calota é de 29,052 \pm $3,976 \mathrm{~mm}$ para o lado esquerdo e $25,062 \pm 4,053 \mathrm{~mm}$ para o lado direito. 


\begin{tabular}{|c|c|c|c|c|c|c|}
\hline Tabela 20 & \multicolumn{6}{|c|}{$\begin{array}{l}\text { Medidas da área }\left(\mathrm{mm}^{2}\right) \text { e distâncias relativas do SVSD }(\mathrm{mm}) \text { à calota craniana } \\
\text { do crânio M8 - São Paulo - } 2006\end{array}$} \\
\hline Cortes & $\begin{array}{l}\text { Área } \\
\text { SVSD } \\
(\mathrm{mm} 2) \\
\end{array}$ & $\begin{array}{c}D 1 \\
\text { (perpendicular) }\end{array}$ & $\begin{array}{c}\text { D2 } \\
\text { (horizontal } \\
\text { esquerda) }\end{array}$ & $\begin{array}{c}D 3 \\
\text { (horizontal } \\
\text { direita) }\end{array}$ & $\begin{array}{c}\text { D4 } \\
\text { (contorno } \\
\text { esquerda) }\end{array}$ & $\begin{array}{c}\text { D5 } \\
\text { (contorno } \\
\text { direita) }\end{array}$ \\
\hline 5 & 5,16 & 2,27 & 16 & 15,74 & 18,38 & 16,15 \\
\hline 6 & 4,6 & 3,11 & 12,13 & 12,85 & 14,98 & 12,04 \\
\hline 7 & 3,46 & 5,8 & 14,3 & 14,11 & 12,15 & 12,08 \\
\hline 8 & 3,99 & 5,45 & 13,81 & 13,07 & 13,65 & 12,5 \\
\hline 9 & 5,29 & 6,49 & 13,54 & 15,02 & 13,34 & 13,34 \\
\hline Média & 4,5 & 4,624 & 13,956 & 14,158 & 14,5 & 13,298 \\
\hline DP & 0,776 & 1,828 & 1,398 & 1,239 & 2,391 & 1,733 \\
\hline
\end{tabular}

Foram encontrados os seguintes valores médios: 4,5 \pm 0,776 para área do SVSD em $\mathrm{mm}^{2}, 4,624 \pm 1,828$ na distância perpendicular e 13,956 $\pm 1,398$ e 14,158 \pm 1,239 para medida horizontal esquerda e direita, em mm. As medidas dos contornos da calota em relação ao SVSD apresentam valores médios de 14,5 $\pm 2,391$ do lado esquerdo e 13,298 \pm 1,733 do lado direito do crânio.

O SVSD tem início na região cranial do arco zigomático (corte 5) e término na região das bulas timpânicas (corte 9). Em relação à área do SVSD, o maior valor é visto no corte 9, onde o SVSD afasta-se da calota craniana, isto é a maior distância perpendicular do ponto seu ponto médio ápice da calota, para unir-se com os seios transversos direito e esquerdo. $\mathrm{O}$ menos valor é visualizado na região da ATM (corte 7).

As medidas relacionadas ás extremidades laterais da calota craniana possuem maior valor ao nível do corte 5 e menor valor nos corte 6 . O maior contorno da calota craniana foi mensurado no corte 5 , e os menores valores nos cortes 6 e 7 . 


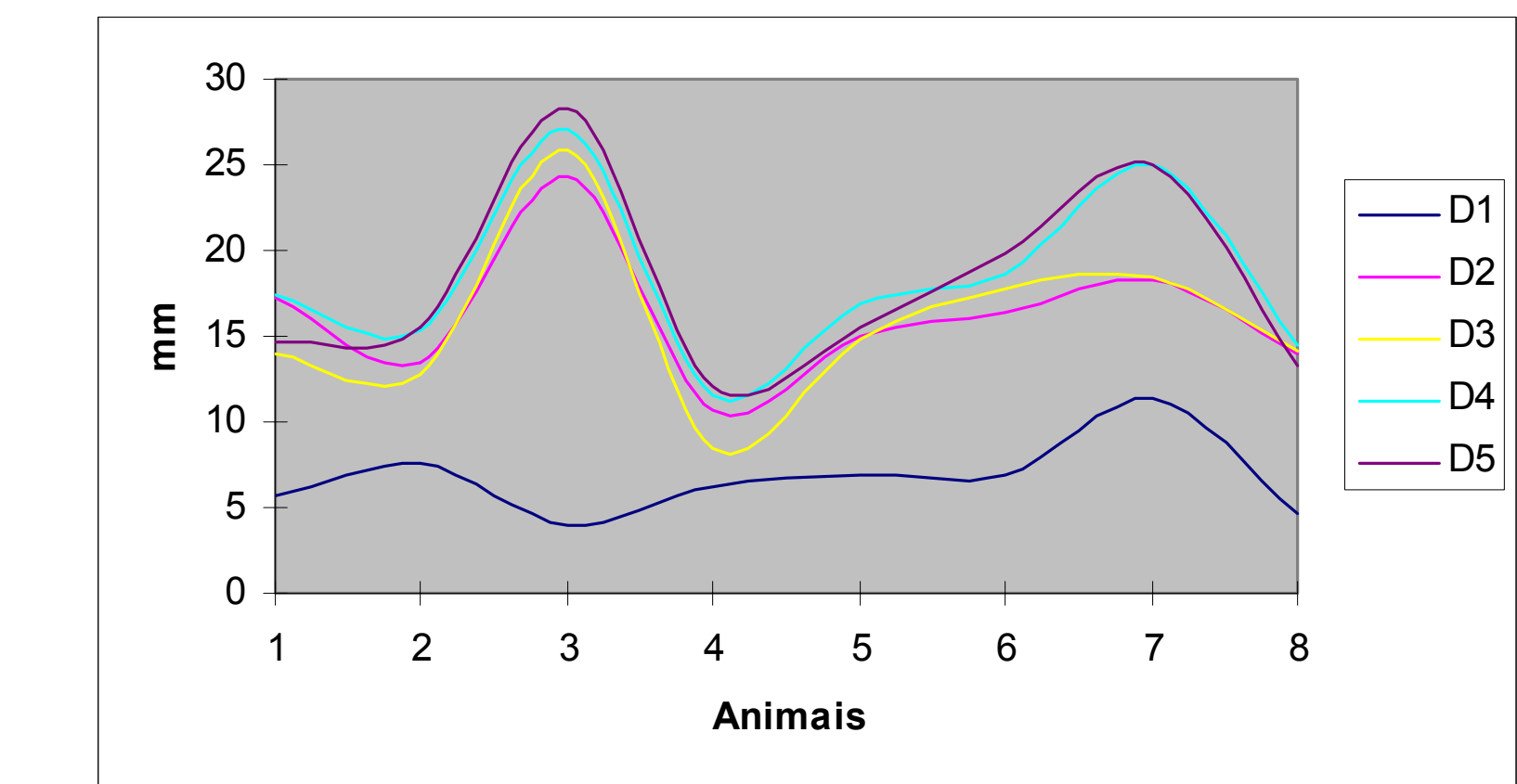

\begin{tabular}{|l|l|}
\hline Figura 22 - & $\begin{array}{l}\text { Gráfico da representação das medidas D1 (perpendicular), D2 (horizontal } \\
\text { esquerda), D3 (horizontal direita), D4 (contorno calota lado esquerdo) e D5 } \\
\text { (contorno calota lado direito), dos animais mesaticefálicos, em mm - São } \\
\text { Paulo - 2006 }\end{array}$ \\
\hline
\end{tabular}

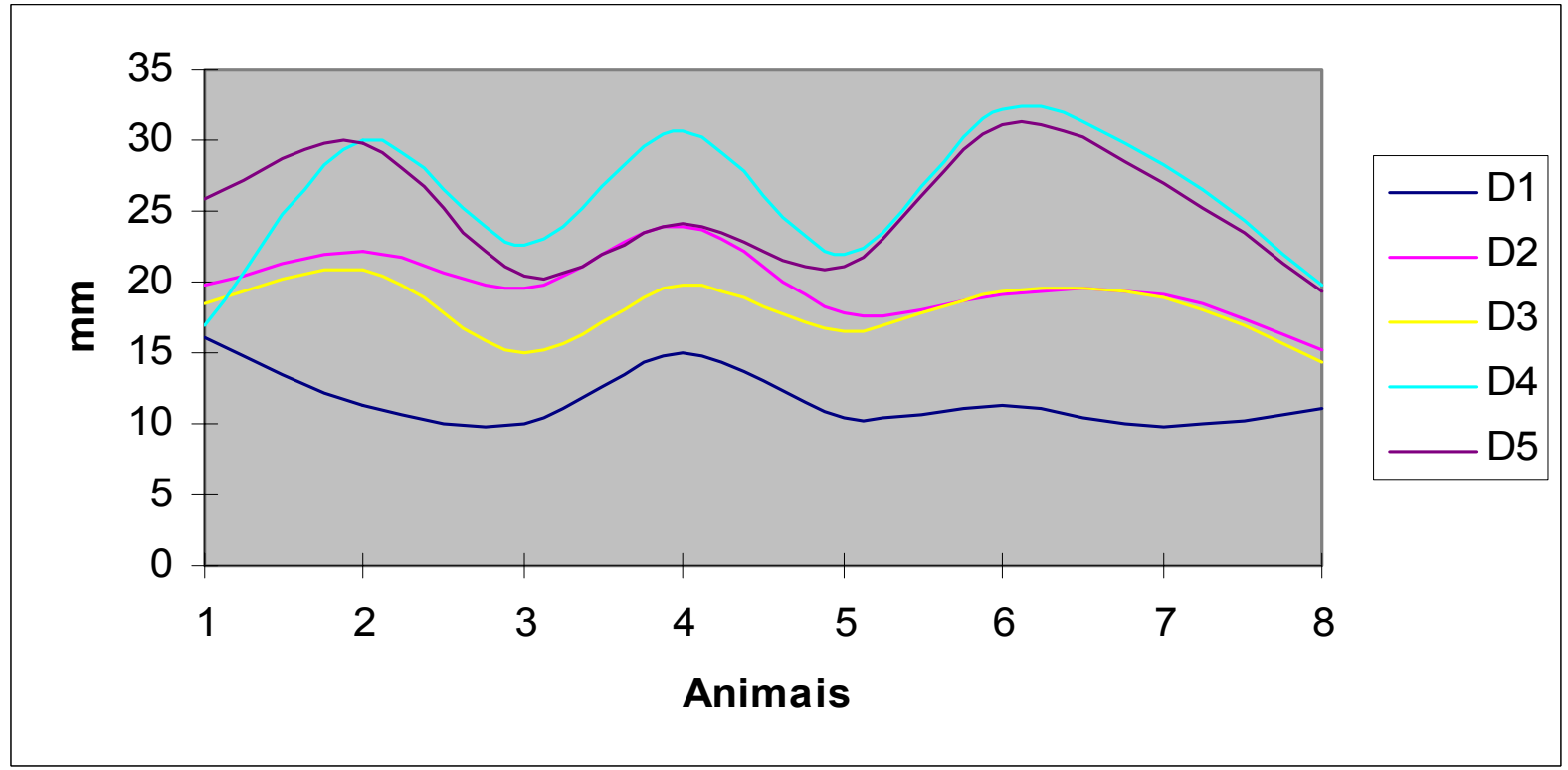

Figura $23-$ Gráfico da representação das medidas D1 (perpendicular), D2 (horizontal esquerda), D3 (horizontal direita), D4 (contorno calota lado esquerdo) e D5 (contorno calota lado direito), dos animais braquicefálicos, em $\mathrm{mm}$ São Paulo - 2006 
Nota-se no gráfico da representação das medidas (figura 21) para os animais mesaticefálicos que os valores das medidas D2, D3, D4 e D5 são próximos e mantêm-se proporcionais. A exceção é o animal número 3 que apresenta valores os valores D1 das medidas restantes na relação inversamente proporcional. No gráfico dos animais braquicefálicos (figura 22) existe semelhança entre os animais e evidencia-se a diferença referente aos valores das medidas D2, D3 em relação à D4 e D5.

Para a abordagem cirúrgica da técnica transfrontal, relacionamos no Apêndice $\mathrm{M}$ Figuras 16 e 17 os dois tipos de crânio e as margens de segurança propostas na literatura. No crânio mesaticefálico, ambas as margens $(0,5$ e $1 \mathrm{~cm})$ lateral à crista sagital mostraram-se seguras, o que não é igual no crânio braquicefálico. 
Tabela 21 - $\quad$ Média da área $\left(\mathrm{mm}^{2}\right)$ doa crânios braquicefálicos e mesaticefálicos - São Paulo $-2006$

\section{Mesaticefálico}

$7,35 \pm 2,51^{\mathrm{a}}$

Área

$$
7,35 \pm 2,51
$$

Média \pm erro padrão. Letras iguais na mesma linha indicam diferença estatística significativa $(\mathrm{P}<0,05)$ pelo teste t de Student.

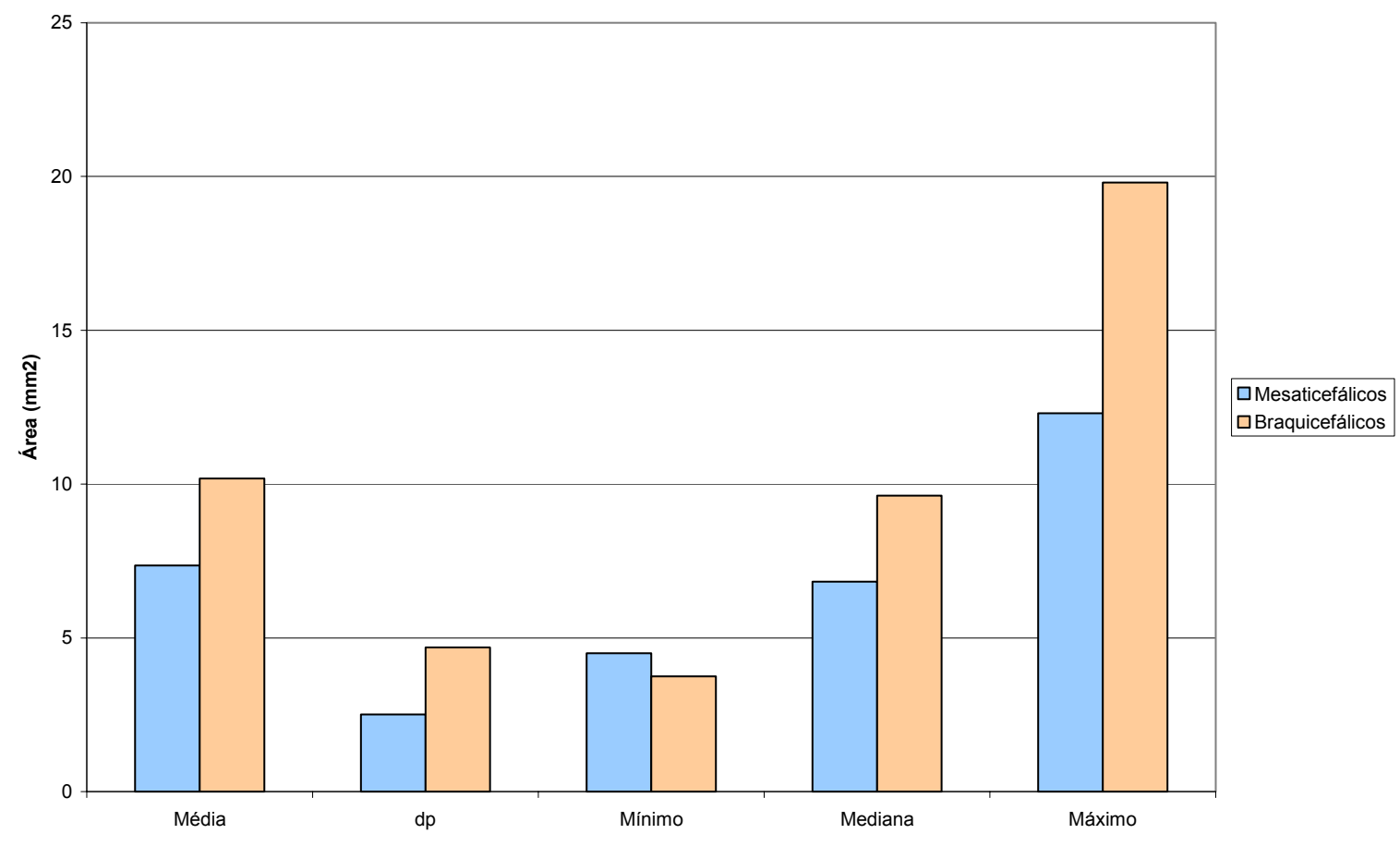

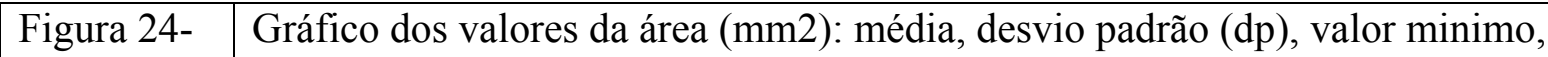 mediana e valor máximo para os animais braquicefálicos e mesaticefálicos - São Paulo - 2006

A área do SVSD apresentou média em $\mathrm{mm}^{2}$ de 7,35 2,51 nos animais mesaticefálicos e 10,18 \pm 4,69 nos braquicefálicos. Não há diferença estatística significante $(\mathrm{P}=0,164<$ 0,05), como demonstra a figura 24. 
Tabela 22 - $\quad$ Média da distância (mm) entre o ponto médio do SVSD e o ápice da calota craniana (D1) dos crânios braquicefálicos e mesaticefálicos - São Paulo - 2006

\section{Mesaticefálico}

\section{D1}

$6,65 \pm 2,27^{\mathrm{a}}$

\section{Braquicefálico}

$11,84 \pm 2,35^{\mathrm{b}}$

Média \pm erro padrão. Letras iguais na mesma linha indicam diferença estatística significativa $(\mathrm{P}<0,05)$ pelo teste t de Student.

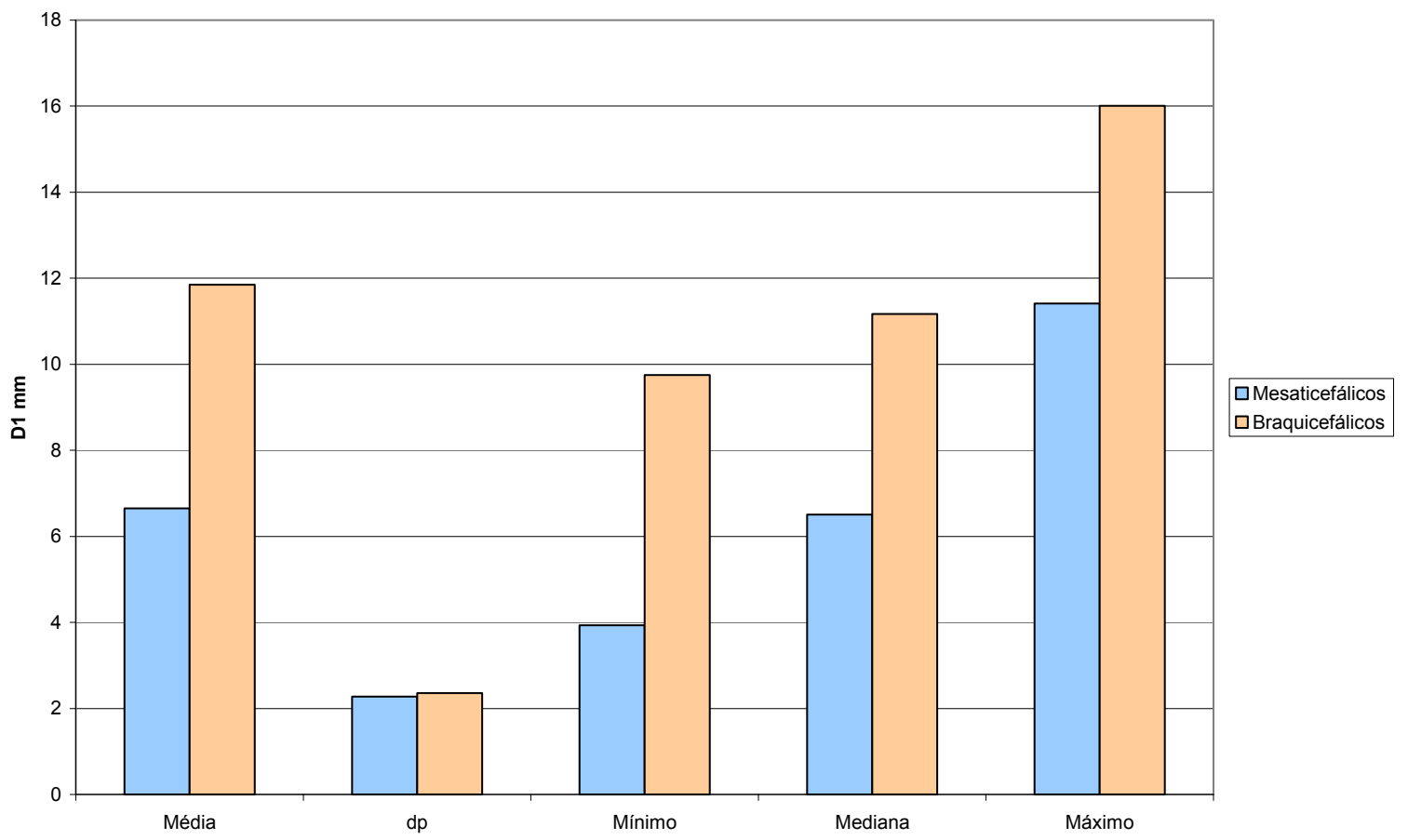

Figura 25- $\quad$ Gráfico dos valores D1 (mm): média, desvio padrão (dp), valor mínimo, mediana e valor máximo para os animais braquicefálicos e mesaticefálicos São Paulo - 2006

Os valores médios de D1 encontrados foram nos mesaticefálicos 6,65 $\pm 2,27$ e nos braquicefálicos $11,84 \pm 2,35$. Os valores apresentam diferença estatística significante $(\mathrm{P}=$ $0,001<0,05)$ (figura 25). 


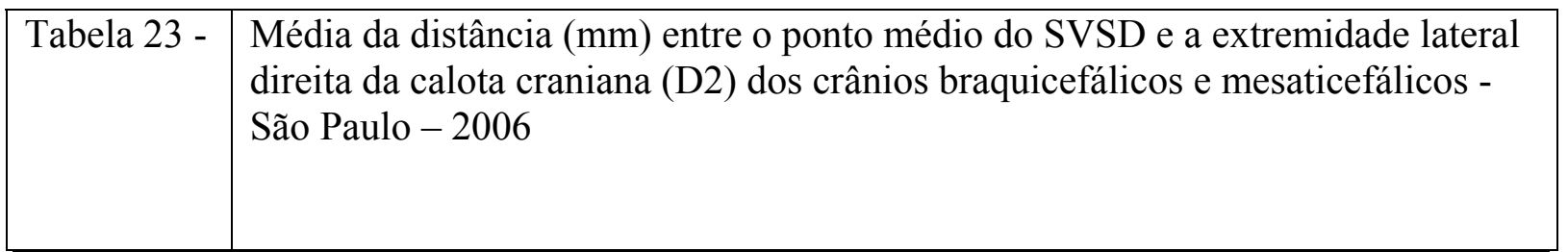

\section{Mesaticefálico $\quad$ Braquicefálico}

D2 $16,17 \pm 4,089^{\mathrm{a}} \quad 19,57 \pm 2,61^{\mathrm{b}}$

Média \pm erro padrão. Letras iguais na mesma linha indicam diferença estatística significativa $(\mathrm{P}<0,05)$ pelo teste $\mathrm{t}$ de Student.

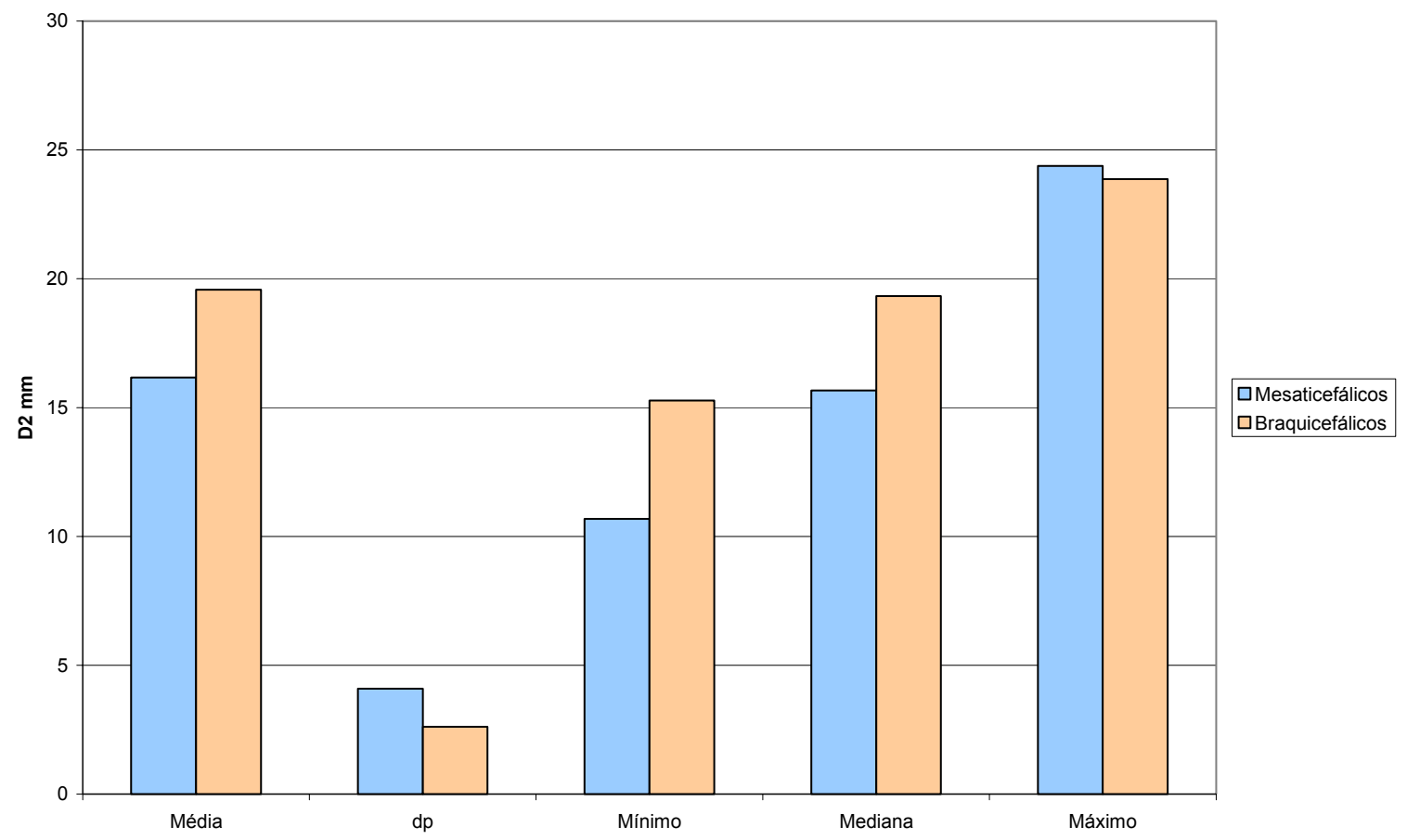

Figura 26- $\quad$ Gráfico dos valores D2 $(\mathrm{mm})$ : média, desvio padrão (dp), valor mínimo, mediana e valor máximo para os animais braquicefálicos e mesaticefálicos São Paulo - 2006

As medidas médias D2 foram $16,17 \pm 4,089$ e 19,57 $\pm 2,61$ pra mesaticefálicos e braquicefálicos respectivamente. Não há diferença estatística significante entre os grupos $(\mathrm{P}=$ $0,310>0,05)$, como demonstra a figura 25 . 


\begin{tabular}{|l|l|}
\hline Tabela 24 - & $\begin{array}{l}\text { Média da distância (mm) entre o ponto médio do SVSD e a extremidade lateral } \\
\text { direita da calota craniana (D3) dos crânios braquicefálicos e mesaticefálicos - } \\
\text { São Paulo - 2006 }\end{array}$ \\
\hline
\end{tabular}

Mesaticefálico

Braquicefálico

D3

$15,75 \pm 5,09^{\mathrm{a}}$

$17,88 \pm 2,31^{b}$

Média \pm erro padrão. Letras iguais na mesma linha indicam diferença estatística significativa $(\mathrm{P}<0,05)$ pelo teste t de Student.

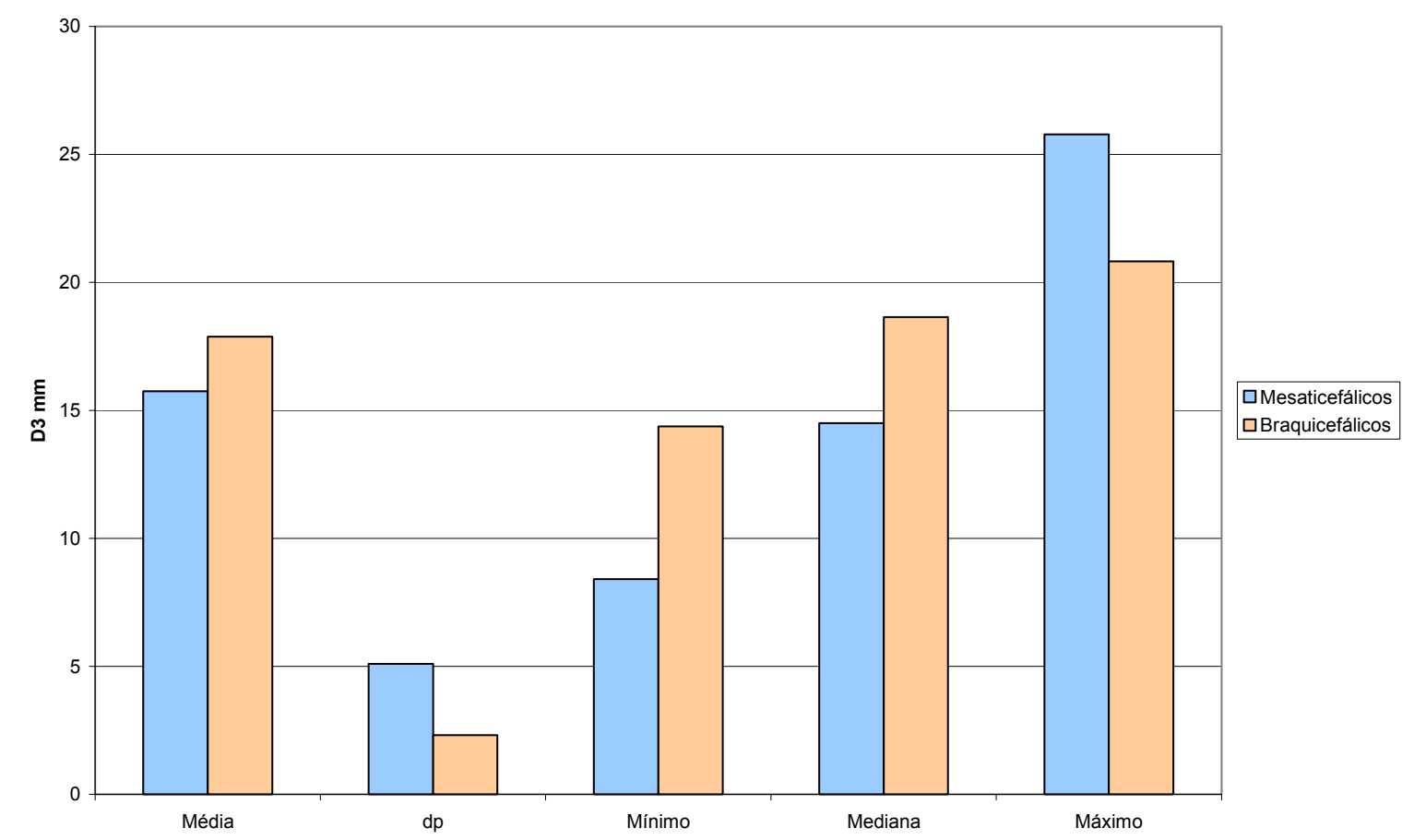

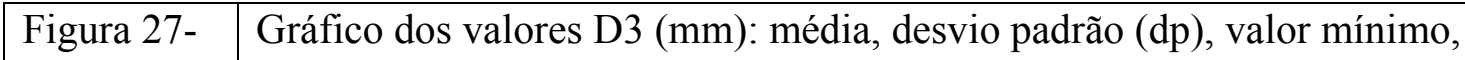
mediana e valor máximo para os animais braquicefálicos e mesaticefálicos São Paulo - 2006

As mensurações de D3 são semelhantes as D2. Os valores médios para os braquicefálicos encontrados foram $17,88 \pm 2,31$ e para os mesaticefálicos $15,75 \pm 5,09$, não apresentando diferença estatística significante $(\mathrm{P}=0,024<0,05)$, o que pode ser visto na figura 27. 


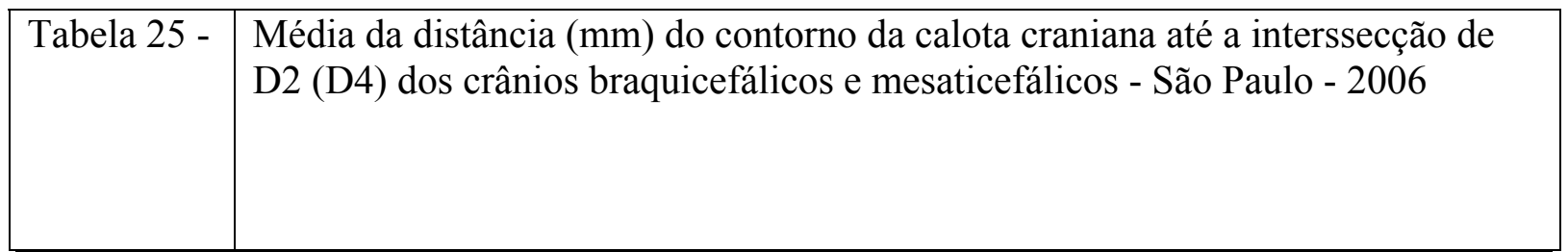

\section{Mesaticefálico $\quad$ Braquicefálico}

D4 $18,33 \pm 5,25^{\mathrm{a}} \quad 25,32 \pm 5,68^{\mathrm{a}}$

Média \pm erro padrão. Letras iguais na mesma linha indicam diferença estatística significativa $(\mathrm{P}<0,05)$ pelo teste $\mathrm{t}$ de Student.

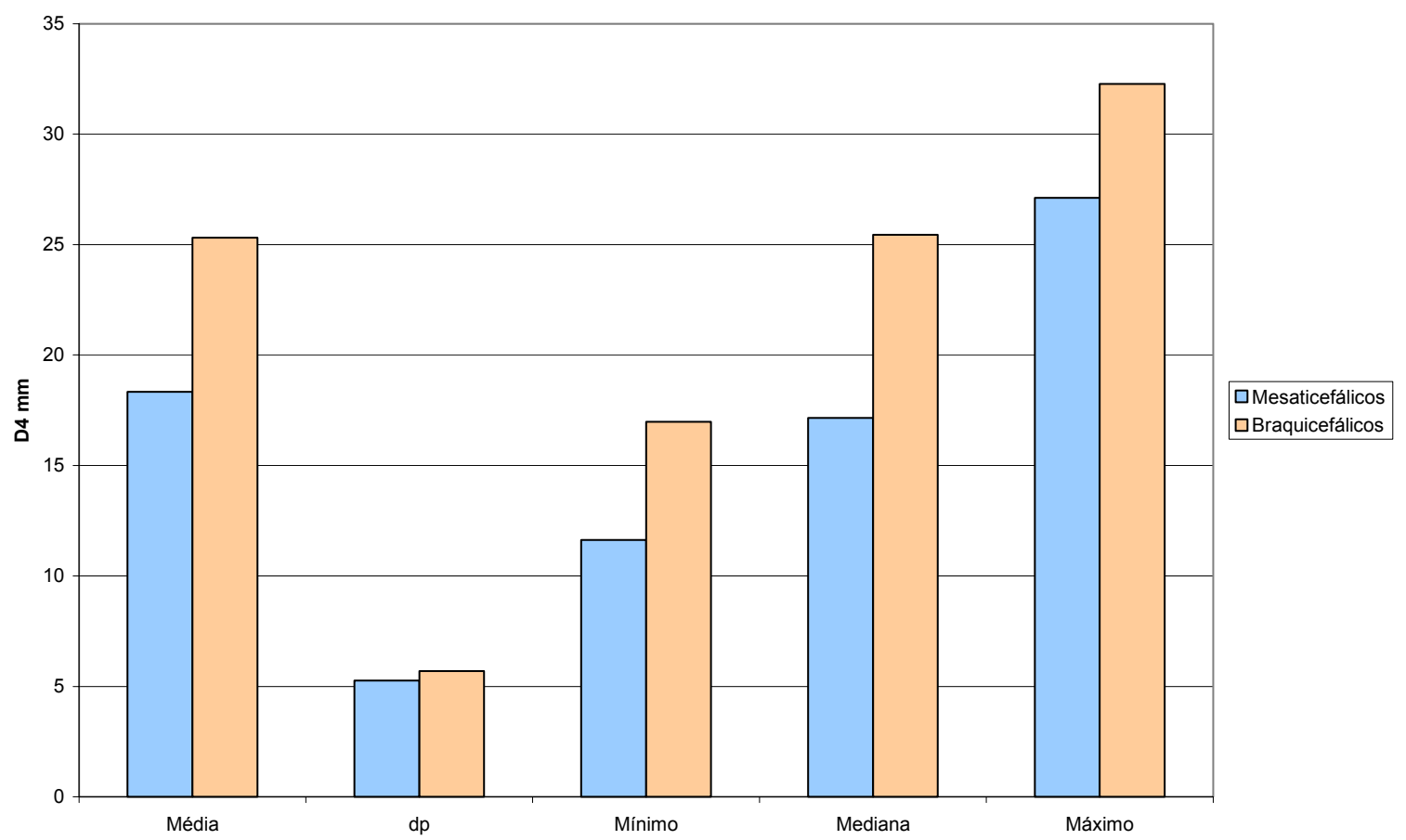

Figura 28- $\quad$ Gráfico dos valores D4 (mm): média, desvio padrão (dp), valor mínimo, mediana e valor máximo para os animais braquicefálicos e mesaticefálicos São Paulo - 2006

A medida D4 apresentou diferença estatística significativa $(P=0,024<0,05)$. Os valores médios são: $18,33 \pm 5,25$ nos mesaticefálicos e 25,32 $\pm 5,68$ nos braquicefálicos (figura 28). 


\begin{tabular}{|l|l|}
\hline Tabela 26 - & $\begin{array}{l}\text { Média da distância (mm) do contorno da calota craniana até a interssecção de } \\
\text { D3 (D5) dos crânios braquicefálicos e mesaticefálicos - São Paulo - 2006 }\end{array}$ \\
\hline
\end{tabular}

\section{Mesaticefálico $\quad$ Braquicefálico}

D5 $18,04 \pm 5,87^{\mathrm{a}} \quad 24,84 \pm 4,40^{\mathrm{a}}$

Média \pm erro padrão. Letras iguais na mesma linha indicam diferença estatística significativa $(\mathrm{P}<0,05)$ pelo teste $\mathrm{t}$ de Student.

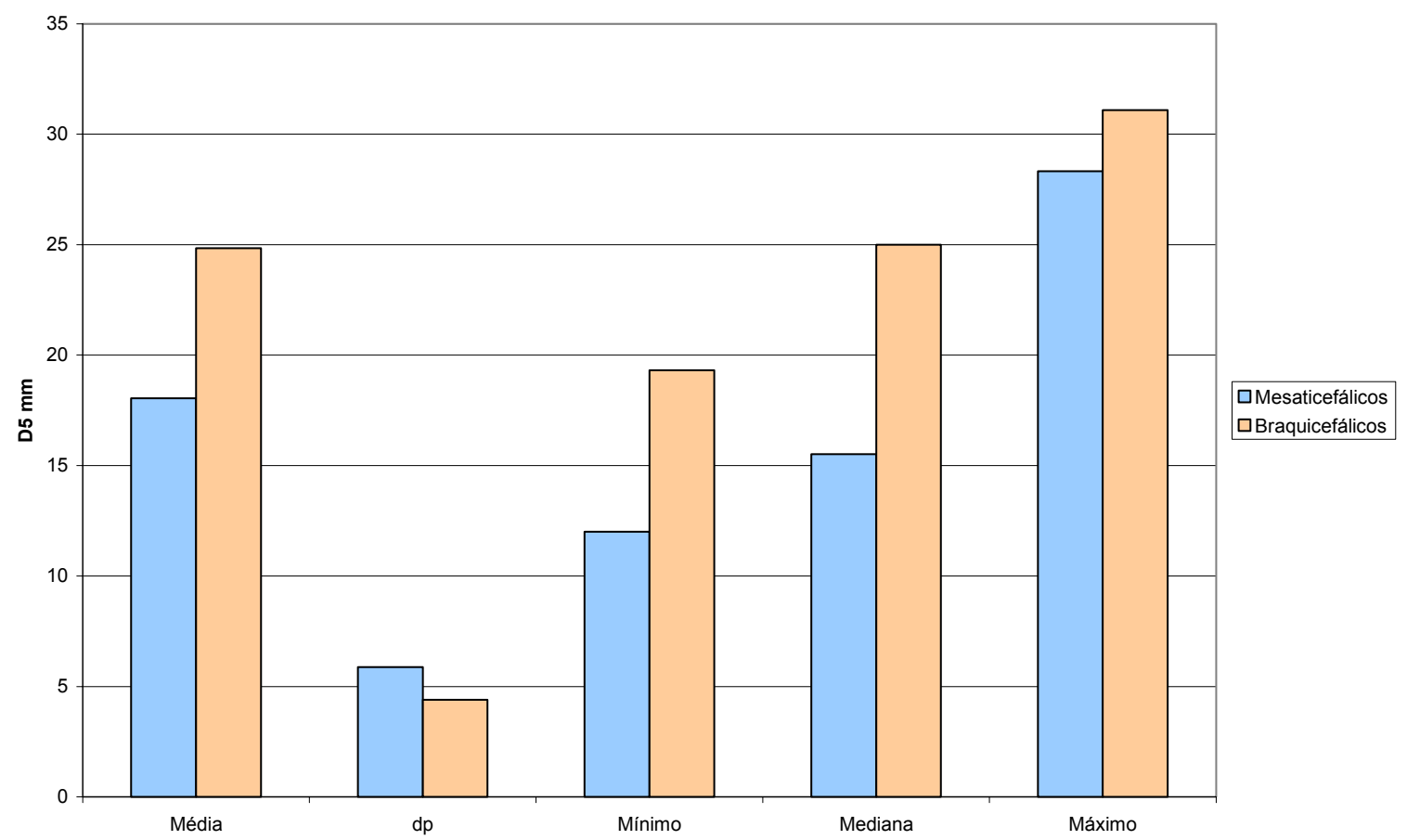

Figura 29 - $\quad$ Gráfico dos valores D5 (mm): média, desvio padrão (dp), valor mínimo, mediana e valor máximo para os animais braquicefálicos e mesaticefálicos São Paulo - 2006

Do mesmo modo que a medida D4, D5 apresentou diferença estatística significante (P $=0,022<0,05)$, com os braquicefálicos apresentando valor médio de $24,84 \pm 4,40$ e os mesaticefálicos $18,04 \pm 5,87$, como mostra a figura 29 . 


\section{DISCUSSÃO}

A cirurgia cerebral em cães foi primeiramente descrita por Hoerlein (1963). Embora a sua realização seja discutida por diversos autores (HOERLEIN; OLIVER JR, 1978; SEIM, 2005; SHORES, 1984), o acesso cirúrgico não é descrito nos diferentes tipos de crânio dos animais. Diante desse fato, este trabalho procurou contribuir com informações relacionados à abordagem cirúrgica, relacionando os acessos já descritos pelos referidos autores, com os diferentes tipos de crânio, principalmente os animais braquicefálicos.

No que tange a morfometria do crânio, vários estudos foram praticados nos últimos cinqüenta anos em diversas espécies como Miller (1979) em cães; Sarma et al. (2002) em felinos e Kalita et al. (2004) utilizando caprinos.

Dyce et al. (1997), Getty (1986) relatam os cães braquicefálicos com crânio amplo e globoso, com a face extremamente curta, o que acarreta o IC com valores próximos a 100. No presente estudo foi examinado através das mensurações, os elevados valores da largura em relação ao comprimento nos animam braquicefálicos. Esse fator, associado ao diminuto comprimento da face nos fez comprovar as características braquicefálicas no IC e ICF dos animais.

Em relação aos animais mesaticefálicos, encontramos valores medianos para as grandezas de comprimento e largura do crânio e comprimento da face. Diferentemente de Evans e Cristenses (1993) que determinaram valores médios de $\mathrm{IC}=52$ para os animais mesaticefálicos, os valores médios encontrados no presente estudo apresentam-se conforme a descrição dos referidos autores. Devido a heterogenicidade deste grupo, composto por cães das raças Rotweiller, Pinscher, Labrador e SRD; os valores de IC são elevados.

Embora Onar (1999) e Onar et al. (2001) descrevam o estudo morfométrico através da maceração dos crânios, para melhor identificação dos pontos de referência, foram utilizadas 
peças anatômicas devidamente formolizadas, realizando assim a palpação das referências anatômicas para posterior mensuração.

Regodon et al. (1991) caracterizaram o sistema venoso cerebral através do uso de contraste á base de sulfato de bário. Baseado nesse estudo foi realizada a técnica de contraste positivo a base de bário. Outros fatores, como solubilidade no látex, viscosidade, utilização de peças anatômicas e baixo custo, foram levados em consideração para o presente estudo.

Realizamos a padronização da amostra, visto que esta era formada de animais grandes e pequenos, com a monitorização da pressão de injeção da solução de contraste e látex com pigmento colorido, evitando assim a ruptura dos vasos de menor calibre e não aumentando a área do SVSD.

Para análise radiográfica dos seios venosos, as radiografias contrastadas obtidas nesse estudo, não foram de grande valia, devido aos artefatos de técnica. Segundo Oliver Jr (1969) e Oribe (2003) as técnicas de angiografia e venografia são úteis para visualização da circulação cerebral, principalmente dos seios venosos. Diferimos dos autores citados pelo fato da injeção de contraste ser realizada na peça anatômica e não no animal in vivo.

Baseado em Hathcock e Stickle (1993) determinamos a tomografia computadorizada como exame de eleição para análise do SVSD que com seus cortes transversais, produz a imagem bi dimensional necessária para avaliação do seu posicionamento em relação à calota craniana.

Para injeção com látex e pigmentos coloridos resultando na coloração e identificação das estruturas venosas e seus ramos colaterais, Reinhard et al. (1962) propôs a injeção pela veia angular do olho. No nosso estudo, a injeção de látex e contraste no sistema venoso foi realizada através das veias jugulares internas e externas, consideradas, por nós, mais fácil para aplicação nas peças anatômicas. 
Concordamos com Pluhar (1997) em referência à localização da vascularização cerebral com intuito diagnóstico e para o tratamento nos procedimentos cirúrgicos.

Para a identificação do trajeto do SVSD, nos baseamos nas imagens da tomografia computadorizada. Diversos autores substituíram métodos invasivos pela imagem para diagnosticar anormalidades neurológicas (COLAÇO ET AL., 2003; ONAR, 2002; RATSH ET AL., 2001). Outros autores como Regodon et al. (1992) que mensuraram o volume craniano e Vite et al. (1997) quantificaram o volume ventricular. Cada corte da imagem tomográfica foi analisado, nele identificado o SVSD e com auxílio da radiografia digital, relacionado com pontos de referência anatômicos. $\mathrm{Na}$ maioria dos animais, tanto no grupo braquicefálico como mesaticefálico, o início do SVSD foi identificado na porção média do arco zigomático e término na região do osso occipital, caudal às bulas timpânicas, como descrito por Machado (2000).

Concordamos com Swayne et al. (1988) sobre a pouca incidência de infarto cerebral associado à trombose venosa. Pudemos observar nas peças anatômicas e nas imagens da tomografia, que existem muitas anastomoses venosas para suprir o tecido cerebral.

Os cães da raça Boxer possuem relativa incidência de neoplasias cerebrais segundo Bagley et al. (1999). Devido a essa predisposição e ao formato do crânio braquicefálico, o nosso estudo levou em consideração especial esse grupo.

$\mathrm{Na}$ análise das imagens, obtivemos valores correspondentes á área do SVSD em mm, no entanto temos ciência do valor relativo apresentado pela introdução da solução de contraste e látex, que possa ter dilatado o calibre do vaso.

Nos dois grupos avaliados, os valores médios da área, D2 e D3 não apresentaram diferenças estatísticas significativas $(\mathrm{P}<0,05)$, entre as mensurações dos crânios dos animais.

Os valores de $\mathrm{D} 1$, são diferentes estatisticamente $(\mathrm{P}<0,05)$, porém não apresentam aplicação prática, visto que o SVSD está localizado na membrana dura mater e permanece 
protegido pela crista sagital externa do crânio. Essa relação pode ser alterada pelo tamanho do crânio e idade do animal, segundo Wet et al. (1982).

Os valores de D2 e D3 estão intimamente relacionados com o formato do crânio, já que representam a distância entre o ponto médio do SVSD às extremidades laterais da calota craniana. Os animais do grupo mesaticefálicos apresentaram valores menores em relação ao grupo braquicefálico, porém equivalentes.

Entre os grupos braquicefálicos e mesaticefálicos, os valores médios de D1, D4 e D5 apresentaram diferença estatística significante $(\mathrm{P}<0,05)$.

As mensurações D4 e D5 apresentam importância primordial, visto que são valores referentes ao contorno da calota craniana, local onde será realizada a incisão para o acesso cirúrgico ao cérebro.

Pela analise da imagem através do software, relacionamos as seguintes características dos crânios dos braquicefálicos: a maior área do SVSD representa também menor distancia do ponto médio do SVSD em relação ao ápice da calota craniana, o formato irregular da calota craniana, com a presença de áreas mais convexas intercalando com áreas côncavas, além do grande contorno (de 20 a $30 \mathrm{~mm}$ ) da calota craniana. Nesse tipo de crânio, notamos que os cortes iniciais do exame tomográfico compreendem a região mais globosa do crânio desses animais. Houve também relação com o arco zigomático que é mais amplo, no que refere á largura, o mesmo relatado por Dyce et al. (1997) e Getty (1986). A partir do processo temporal do arco zigomátido, observamos a formação da crista sagital externa, a partir do osso frontal. Devido à sua maior largura, a crista sagital externa é mais proeminente e muitas vezes palpável, nesses animais apesar da grande musculatura no local.

Em relação às abordagens cirúrgicas, Hoerlein e Oliver Jr. (1978), Seim (2005) e Shores (1984), descrevem pontos de referência e dentre esses o seio venoso sagital dorsal. Tendo em vista que os acessos propostos fornecem apenas uma informação generalizada da 
margem de segurança nos diferentes tipos de crânio, o nosso estudo demonstra a distância real do seio venoso sagital dorsal para as incisões. Concordamos com a relação sugerida, no entanto, esta foi comparada nos crânios braquicefálicos e mesaticefálicos.

$\mathrm{O}$ arco da calota craniana, visualizado e mensurado no presente trabalho apresenta-se de forma diferente nos crânios comparados no estudo. Nos crânios mesaticefálicos os valores referentes ás distâncias horizontal do ponto médio do SVSD às extremidades laterais direita e esquerda (D2 e D3) e as medidas do contorno da calota ao mesmo ponto (D4 e D5) são muito próximos. O mesmo não é visto nos crânios braquicefálicos, nos quais o formato da calota não é uniforme. As mensurações do contorno da calota (D4 e D5) são mais extensas quando comparadas às distâncias D2 e D3.

Devido à conformação do crânio dos braquicefálicos, que apresentam um contorno mais extenso (em $\mathrm{mm}$ ) com a margem de segurança proposta de $0,5 \mathrm{~cm}$ há risco de laceração do SVSD. O crânio dos mesaticefálicos, pela convexidade uniforme, há menor valor em extensão da calota e conseqüentemente a margem de segurança de $0,5 \mathrm{~cm}$ é apropriada para a abordagem cirúrgica.

Mesmo na abordagem caudo tentorial há risco de laceração de seios venosos. Apesar do SVSD terminar próximo ao osso occipital, é um seio comunicante e une-se aos seios transversos direito e esquerdo, portando ainda há risco de laceração venosa.

Nas técnicas para acesso intracraniano propostas por Hoerlein, Oliver Jr. (1978) os acessos são realizados conforme a localização da lesão. Devido ao tamanho do crânio, muitas vezes reduzido em algumas raças, uma ampla abordagem deve ser cautelosa a fim de evitar traumatismos iatrogênicos de estruturas importantes do cérebro. Nos animais com a conformação braquicefálica, a abordagem pode ser ampla pelo tamanho do crânio, porém deve-se evitar a incisão próxima à crista sagital externa, como demonstra o presente estudo. 
Os animais mais acometidos por hidrocefalia são os de raças toy e com formato característico do crânio. Gage e Hoerlein (1968) apontaram que a cirurgia para reduzir a quantidade de liquido cérebro espinhal é efetiva e têm $86 \%$ de sucesso. No presente estudo não foram estudados os animais mais predispostos á hidrocefalia, porém a abordagem cirúrgica para a inserção de cateteres nos ventrículos, distantes 2 a $4 \mathrm{~mm}$, como citados pelos referidos autores, não ocasionaria lesão do SVSD pelo que foi relatado.

Em alguns casos, geralmente neoplasias, as ressecções totais são necessárias (LAWSON et al., 1982; SHELL et al.,1993). Alguns tumores, como meningiomas localizamse na dura mater, conseqüentemente muito próximo aos seios venosos. A abordagem cirúrgica para ressecção deve ser cautelosa e com uma distância segura das estruturas venosas. Alguns autores (GLASS et al., 2000; REGODON et al.,1996), descrevem técnicas para abordagem craniana modificadas, relatando margem de segurança de $0,5 \mathrm{a} 1 \mathrm{~cm}$ lateral à linha média. Segundo o presente trabalho, algumas raças com formato do crânio braquicefálicos necessitam de uma margem mais ampla, pelas proporções já demonstradas.

Glass et al. (2000) descrevem a técnica transfrontal bilateral para acesso a região frontal do cérebro. Na técnica deve ser feito o reposicionamento de dois flaps ósseos, da calota e do seio frontal. Há grande risco de traumatismo ao SVSD, visto que o acesso localiza-se na porção inicial do seio venoso. Na revisão de Niebauer et al. (1991) foram avaliados durante 5 anos, animais submetidos à cirurgia intracraniana. As técnicas e acessos cirúrgicos foram realizados como descrito na literatura. Os autores relatam o tipo e severidade das lesões, a experiência e habilidade da equipe cirúrgica e tempo trans operatório como fatores responsáveis para o sucesso do procedimento. Acreditamos que com o presente estudo, as diferenças estabelecidas para os tipos de crânio acrescentem conhecimento para a experiência de cirurgiões, e em decorrência, procedimentos bem sucedidos. 


\section{CONCLUSÃO}

Com base no presente estudo, podemos concluir que:

$\checkmark$ O SVSD localiza-se nas pregas da membrana dura mater, na região da foice do cérebro.

$\checkmark$ O trajeto do SVSD tem início na região correspondente à porção média do arco zigomático término na região do osso occipital.

$\checkmark$ O crânio dos animais braquicefálicos possui o formato característico, com uma porção convexa e o restante côncava; e é amplamente globoso.

$\checkmark$ O exame da tomografia computadorizada é eficiente na produção de imagens intracranianas como auxílio diagnóstico.

$\checkmark$ Existe diferença significativa entre o ponto médio do SVSD e o ápice da calota craniana (D1) entre os crânios braquicefálicos e mesaticefálicos.

$\checkmark$ Existe diferença significativa entre a distância do contorno da calota craniana bilateralmente entre braquicefálicos e mesaticefálicos.

A margem de segurança para acesso cirúrgico ao cérebro deve ser maior que $0,5 \mathrm{~cm}$ nos crânios braquicefálicos.

$\checkmark$ A margem de segurança para acesso cirúrgico ao cérebro de $0,5 \mathrm{~cm}$ é segura nos crânios mesaticefálicos. 


\section{REFERÊNCIAS}

BAGLEY, R. S.; GAVIN, P. R.; MOORE, M. P.; SILVER, G. M.; HARRINGTON, M. L.; CONNORS, R.L. Clinical signs associated with brain tumors in dogs : 97 cases (1992-1997). Journal of American Veterinary Medical Association, v. 215, n. 6, p. 818-819, 1999.

BAGLEY, R. S.; HARRINGTON, M. L.; PLUHAR, G. E.; KEEGAN, R. D.; GREENE, S. A.; MOORE, M. P.; GAVIN, P. R. Effect of craniotomy/durotomy alone and in combination with hyperventilation, diuretics, and corticosteroids on intracranial pressure in clinically normal dogs. American Journal Veterinary Research, v. 57, p. 116-119, 1996.

BRYANT, K. J.; STEINBERG, H.; McANULTY, J. F. Cranioplasty by means of molded polymethylmethacrylate prosthetic reconstruction after radical excision of neoplasms of the skull in two dogs. Journal of American Veterinary Medical Association, v. 223, n. 1, p. 67-72, 2003.

DE WET, P. D.; ALI, I. I.; PETERS, D. N. Surgical approach to the rostral cranial fossa by radical transfrontal craniotomy in the dog. Journal of South African Veterinary

Association, v. 23, n. 1, p. 40-51, 1982.

DYCE, K, M.; SACK, W. O., WENSING, C. J. G. Tratado de anatomia veterinária. 2. ed. Rio de Janeiro: Guanabara Koogan, 1997. p. 359-384

EMILY, P.; PENMAN, S. Handbook of small animal dentistry. 2.ed. Oxford: Pergamon Press, 1994. p. 1-4.

EVANS, H. E.; CHRISTENSEN, G. C. Miller's anatomy of the dog. Philadelphia: Saunders, 1993, p. 13-45.

FIKE, J. R., LE COUTEUR, R. A.; CANN, C. E. Anatomy of the canine brain using high resolution computed tomography. Veterinary Radiology, v. 22, n. 6, p. 236-243, 1981.

GAGE, E.D.; HOERLEIN, B. F. Surgical treatment of canine hydrocephalus by ventriculoatrial shunting. Journal of American Veterinary Medical Association, v. 153, p. 1418-1431, 1968.

GETTY, R. Anatomia dos animais domésticos. 5. ed. Rio de Janeiro: Guanabara Koogan, 1986, v. 2, p. 1377-1391.

GLASS, E. N.; KAPATKIN, A.; VITE, C.; STEINBERG, S. A. A modified bilateral transfrontal sinus approach to the canine frontal lobe and olfactory bulb: surgical technique and five cases. Journal of the American Animal Hospital Association, v. 36, p. 43-50, 2000 .

HATHCOCK, J. T.; STICKLE, R. L. Principles and concepts of computed tomography. Veterinary Clinics of North America: Small Animal Practice. v. 23, n. 2, p. 399-435, 1993. 
HIGGINS, R. J.; LECOUTEUR, R. A.; VERNAU, K. M.; STURGES, B. K.;

OBRADOVICH, J. E.; BOLLEN, A.W. Granular cell tumor of the canine central nervous system: two cases. Veterinary Pathology, v. 38, p. 620-627, 2001.

HOERLEIN, B. F., FEW, A. B., PETTY, M. F. Brain surgery in the dog - preliminary studies. Journal of American Veterinary Medical Association, v. 143, n. 1, p. 21-29, 1963.

KALITA, A.; SARMA, K., SHALINI SURI, M. M. S.; AHMAD, B. Craniometrical study in Bakarwali Goat. Indian Journal Animal Heatlh, v. 43, n. 2, p. 180-184, 2004.

KING, A. S. Physiological and clinical anatomy of the domestic mammals.1.ed: Oxford Science Publications, 1987, v. 1 p.24-30.

KUMAR, A. J.; HOCHWALD, G. M.; KRICHEFF, I. An Angiographic study of the carotid arterial and jugular venous systems in the cat. American Journal of Anatomy. v. 145, p. 357-370, 1975.

LAWSON, D. C.; BURK, R. L.; PRATA, R. G. Cerebral meningioma in the cat: diagnosis and surgical treatment of ten cases. Journal of the American Animal Hospital Association. v. 20, p. 333-342, 1984.

LIGNEREUX, Y.; REGODON, S.; PAVAUX, C. Typologie Céphalique Canine. Revue Médicine Véterinarie, v. 142, n. 6, p. 469-480, 1991.

NIEBAUER, G. W.; DAYRELL-HART, B. L.; SPECIALE, J. Evaluation of craniotomy in dogs and cats. Journal of American Veterinary Medical Association, v. 198, n. 1. p. 89-95, 1991.

OLIVER JR., J.E. Surgical approaches to the canine brain. American Journal of Veterinary Research, v. 29, n. 2, p. 353-378, 1968.

ONAR.V. A Morphometric study on the skull of the german Shepherd Dog (Alsatian). Anatomy Histology Embryology. v. 28, p. 253-256, 1999.

ONAR, V.; KAHVECIOGLU, K. O.; CEBI, V. Computed tomography analysis of the cranial cavity and neurocranium in German Shepherd dog (Alsatian) puppies. Veterinarski Arhiv, v. 72, n. 2, p. 57-66, 2002.

ONAR.V.; ÖZCAN, S.; PAZVANT, G. Skull Typology of Adult Male Kangal Dogs. Anatomy Histology Embryology. v. 30, p. 41-48, 2001.

PARKER, A. J.; CUNNINGHAM, J. G. Transfrontal craniotomy in the dog. Veterinary Research. v. 90, p. 622-624, 1972.

PLUHAR, G. E.; TUCKER, M. S.; GAVIN, P. R.; BAGLEY, R. S.; TAKEUCHI, M. Cerebral sinus venography in the dog: a new technique. Veterinary Radiology \& Ultrasound, v. 38, n. 2, p. 112-115, 1997. 
RATSCH, B. E., KNEISSL, S.; GABLER, C. Comparative evaluation of the ventricles in Yorkshire terrier and the german shepherd dog using low field MRI. Veterinary Radiology \& Ultrasound, v. 42, n. 5, p. 410-413, 2001.

RODRIGUES, H. Angiotécnicas. IN: RODRIGUES, H. Técnicas anatômicas, 2. ed. Vitória ES; 1998, p.91-131.

REGODON, S.; FRANCO, A.; LIGNEREUX, Y.; GARIN, J.; MARTIN, A. Lê Volume Crânien chez lê pékinois recherche tomodensitométrique, différence liée au sexe. Revue Médicine Véterinarie, v. 143, n. 10, p. 745-748, 1992.

REGODON, S.; FRANCO, A.; LIGNEREUX, Y.; MASOT, A. J.; REDONDO, E. Access to the encephalic ventricles in the dog: a new technique. Revue Médicine Véterinarie, v. 147, n. 5, p. 383-386, 1997.

REGODON. S.; ROBINA, A.; FRANCO, A.; VIVO, J. M.; LIGNEREUX, Y. Determination Radiologique et Statistique dês Types Morphologiques Crâniens chez lê Chien:

Dolichocéphalie, Mésocéphalie et Brachycéphalie. Anatomy Histology Embryology, v. 20, p. 129-138, 1991.

REGODON, S.; VIVO, J. M.; MAYORAL, A. I.; ROBINA, A.; LIGNEREUX, Y. Étude radiologique dês variations topographiques crânio-encéphaliques chez lês chiens: dolicho-, meso- et brachycéphales. Revue Médicine Véterinarie, v. 141, n. 6, p. 479-483, 1990.

REINHARD, K. R.; MILLER, M. E., EVANS, H. E. The craniovertebral veins and sinuses of the dog. American Journal Anatomy, v. 111, p. 67-87, 1962.

SACK, W. O.; HABEL, H. E. Nomina anatomica veterinária. 1 ed. Committes, 1994, p.1037.

SAITO, M.; OLBY, N. J.; SPAULDING, K.; MUNANA, K.; SHARP, N. J. H. Relationship among basilar artery resistance index, degree of ventriculomegaly, and clinical signs in hydrocephalic dogs. Veterinary Radiology \& Ultrasound. v. 44, n. 6, p. 687-694, 2003.

SARMA, M.; KALITA, A.; BAISHYA, A.; GOSWAMI, R. N. Craniometry in domestic cat. Indian Veterinary Journal. v. 79, p. 1262-1265, December 2002.

SEIM, H. B. Brain surgery. In: FOSSUM, T. W. Cirurgia de pequenos animais. 2 ed, São Paulo: Roca, 2005, p. 1322-1344.

SHELL, L.; COLTER, B. B.; BLASS, C. E.; INGRAM, J. T. Surgical Removal of a meningioma in a cat after detection by computerized axial tomography. Journal of the American Hospital Association. v. 21, p. 439-442, 1985.

SHORES, A. Intracranial surgery. IN: SLATTER, D. Textbook of small animal surgery. 2.ed. Philadelphia: W.B.Saunders Company, 1993, p. 1122-1141.

SORJONEN, D. C.; THOMAS, W. B.; MYERS, L. J.; COX, N. R. Radical cerebral cortical resection in dogs. Progress in Veterinary Neurology. v. 2, n. 4, p. 225-235, 1991. 
SHORES, A. Use of the ultrasonic aspirator in intracranial surgery: technique and case reports. Progress in Veterinary Neurology. v. 2, n. 2, p. 89-94, 1991

SHORES,A. Instrumentation for intracranial surgery. Progress in Veterinary Neurology. v. 2, n. 3, p. 175-182, 1991.

SWAYNE, D. E.; TYLER, D. E.;BATKER, J. Cerebral infarction with associated venous trombosis in a dog. Veterinary Pathology. v. 25, p. 317-320, 1988.

THOMAS, W. B. Cerebrovascular disease. IN: Intracranial disease. Veterinary clinics of North American: Small Animal Pactice. v. 26, n. 4, p. 925-943, 1996

VITE, C. H., INSKO, E. K., SCHOTLAND, H. M., PANCKERI, B. A., HENDRICKS, J. C. Quantification of cerebral ventricular volume in English bulldogs. Veterinary Radiology \& Ultrasound, v. 38, n. 6, p. 437-443, 1997. 
APÊNDICE A

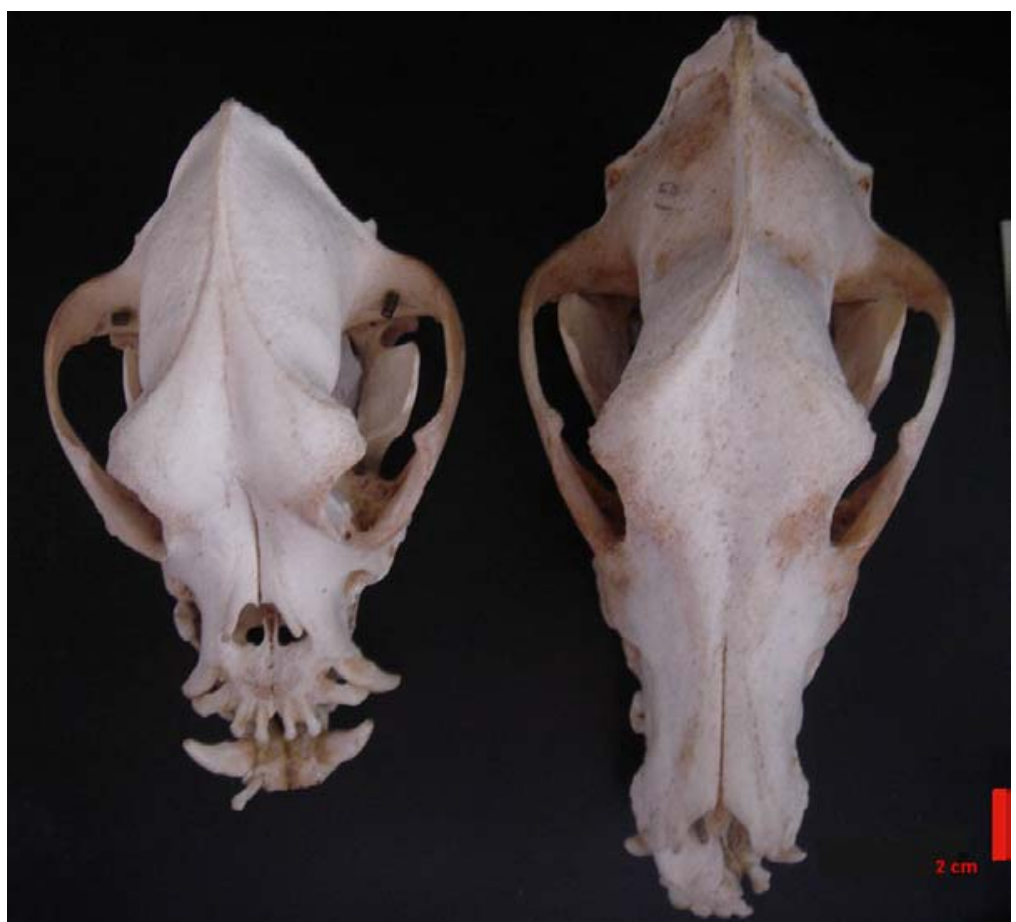

Figura 1 - Crânio braquicefálico (esquerda) e mesaticefálico (direita) - São Paulo 2006

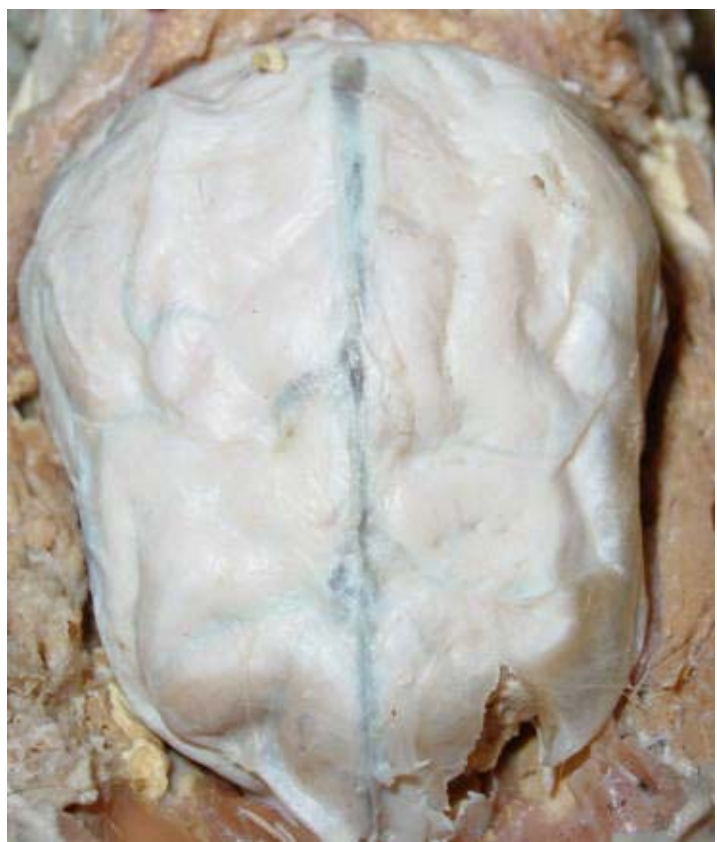

Figura 2 - Seio Venoso Sagital Dorsal (SVSD) - São Paulo - 2006 


\section{ESQUEMA SEIOS VENOSOS DA DURA MATER}

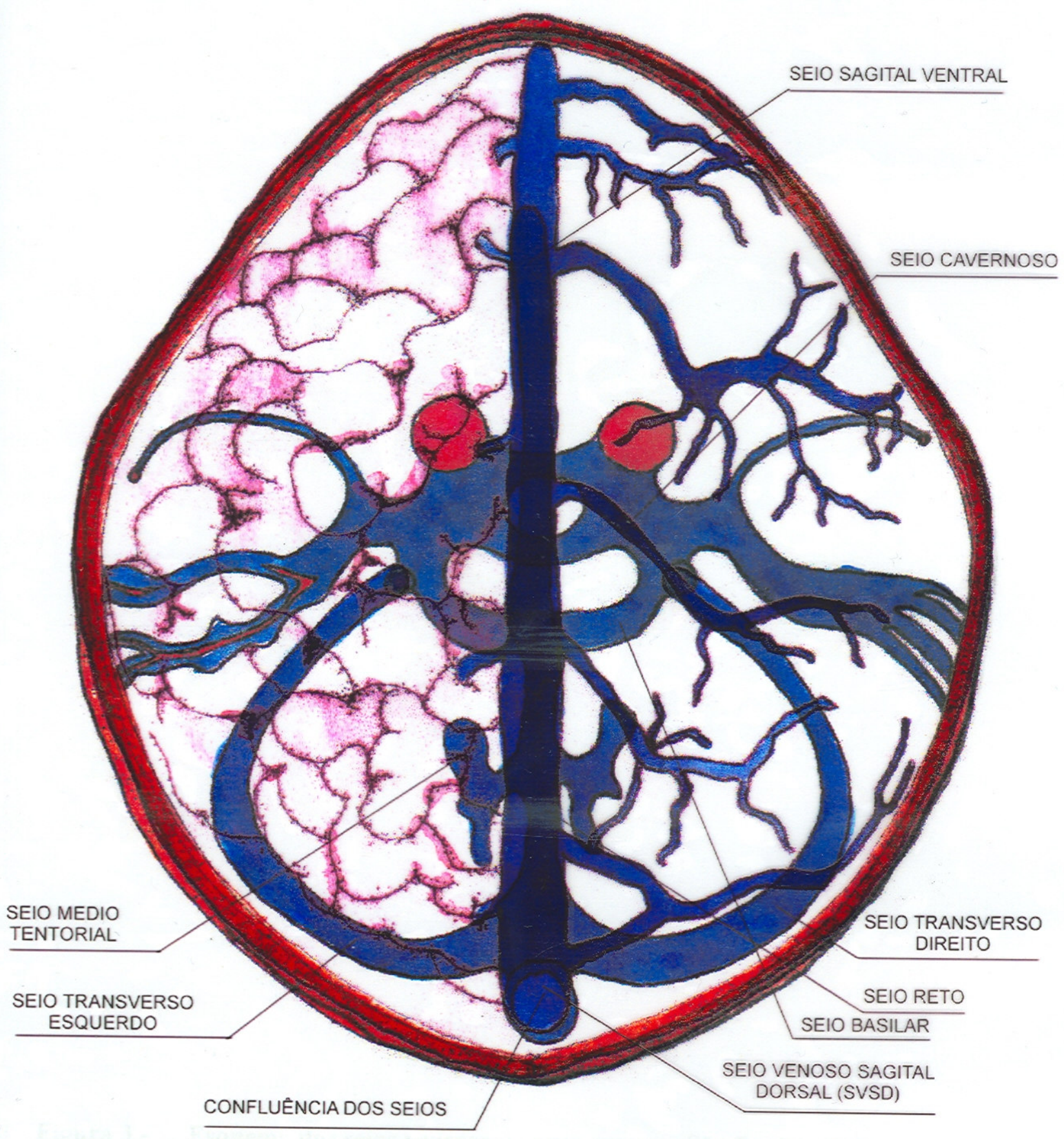


APÊNDICE B

Figura 3 - Esquema dos seios venosos da dura mater - São Paulo - 2006 
APÊNDICE C

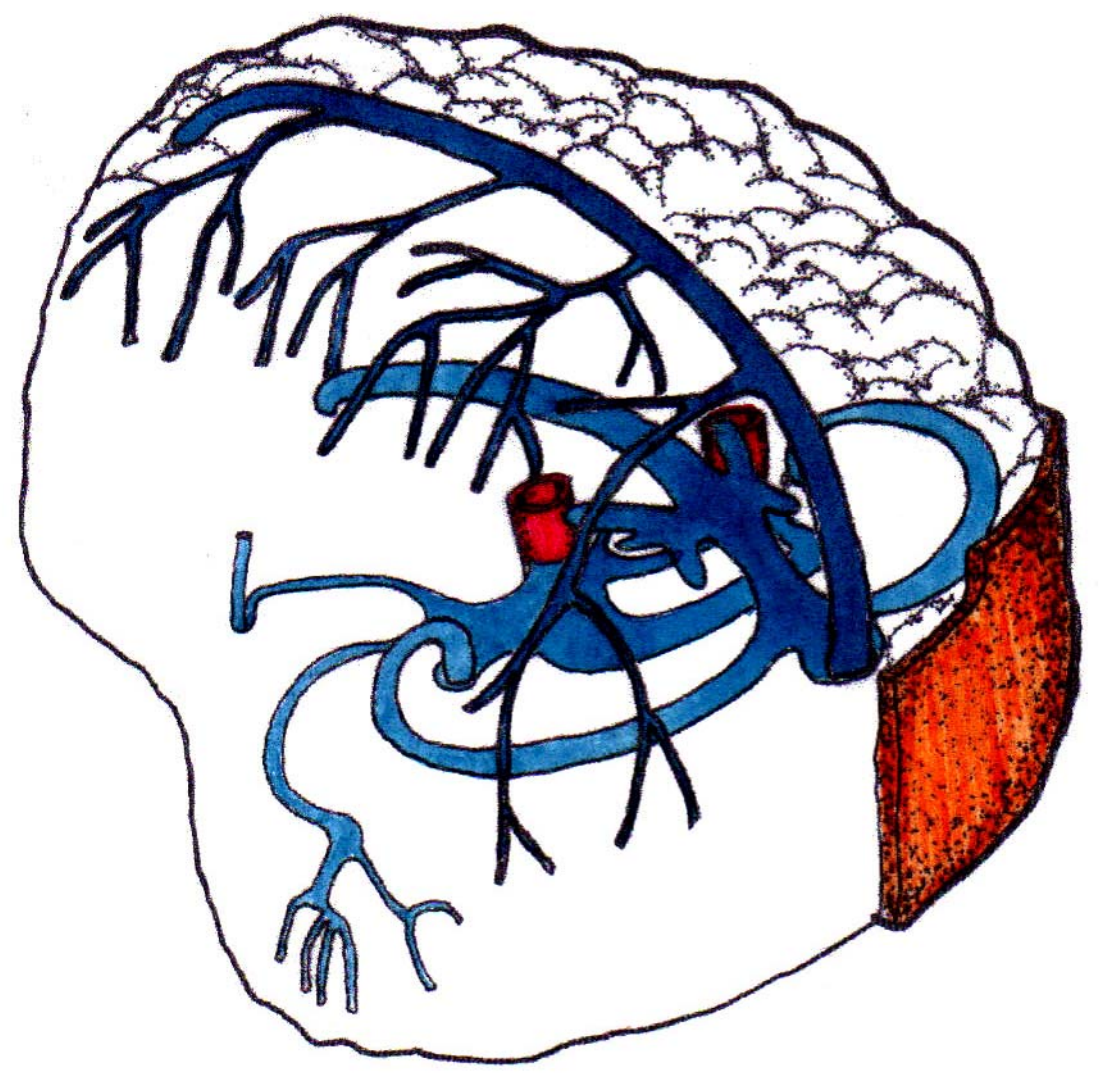

Figura 4 - Representação dos seios venosos da dura mater - São Paulo - 2006 


\section{APÊNDICE D}

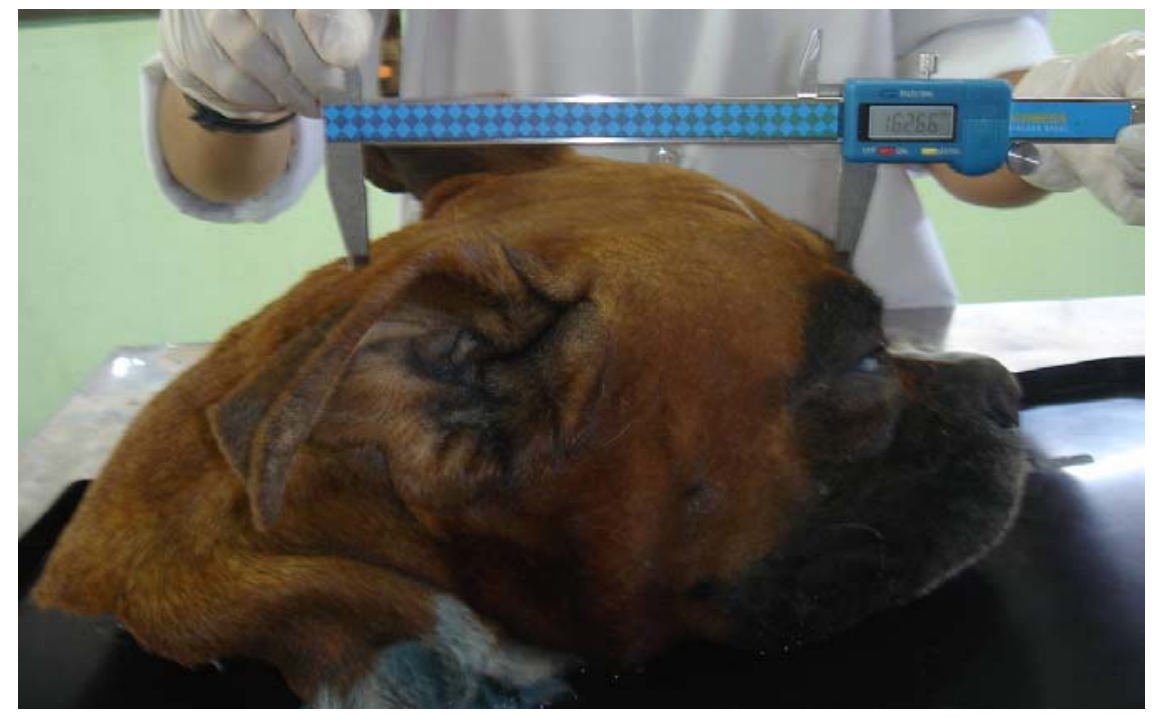

Figura 5 - Mensuração do comprimento do crânio - São Paulo - 2006
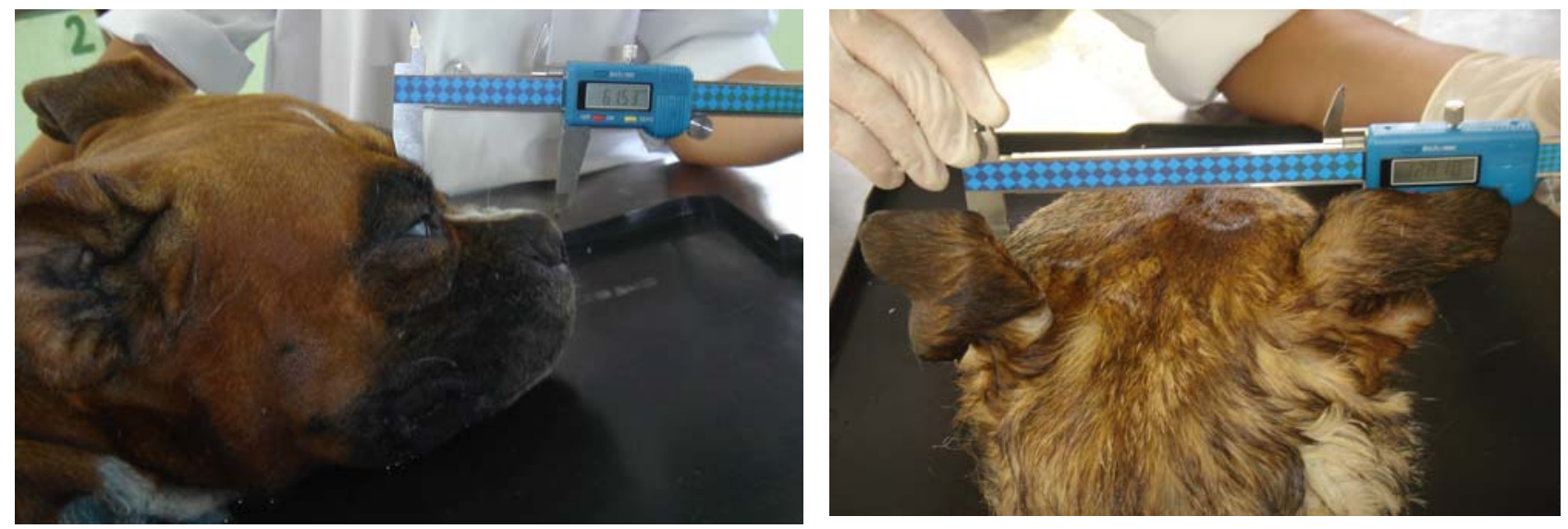

Figura 6 e 7 - Mensuração comprimento da face (esquerda) e largura do crânio (direita) - São Paulo - 2006 
APÊNDICE E

a)

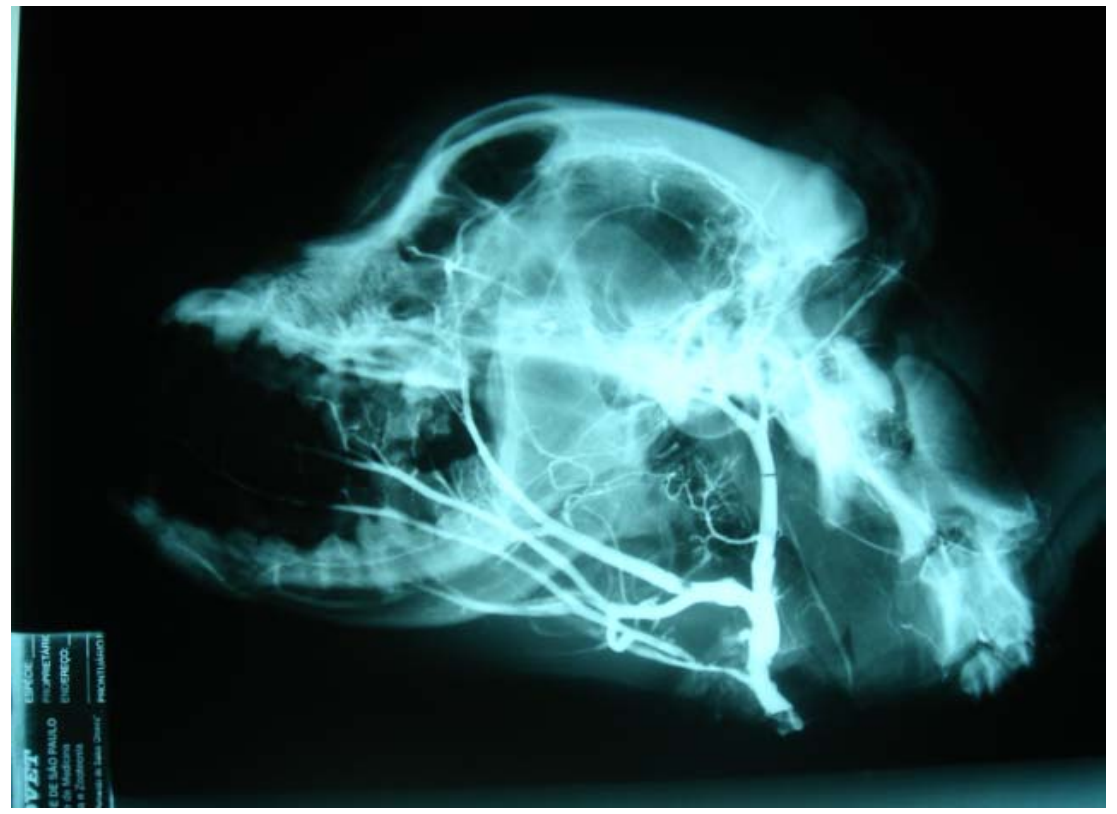

b)

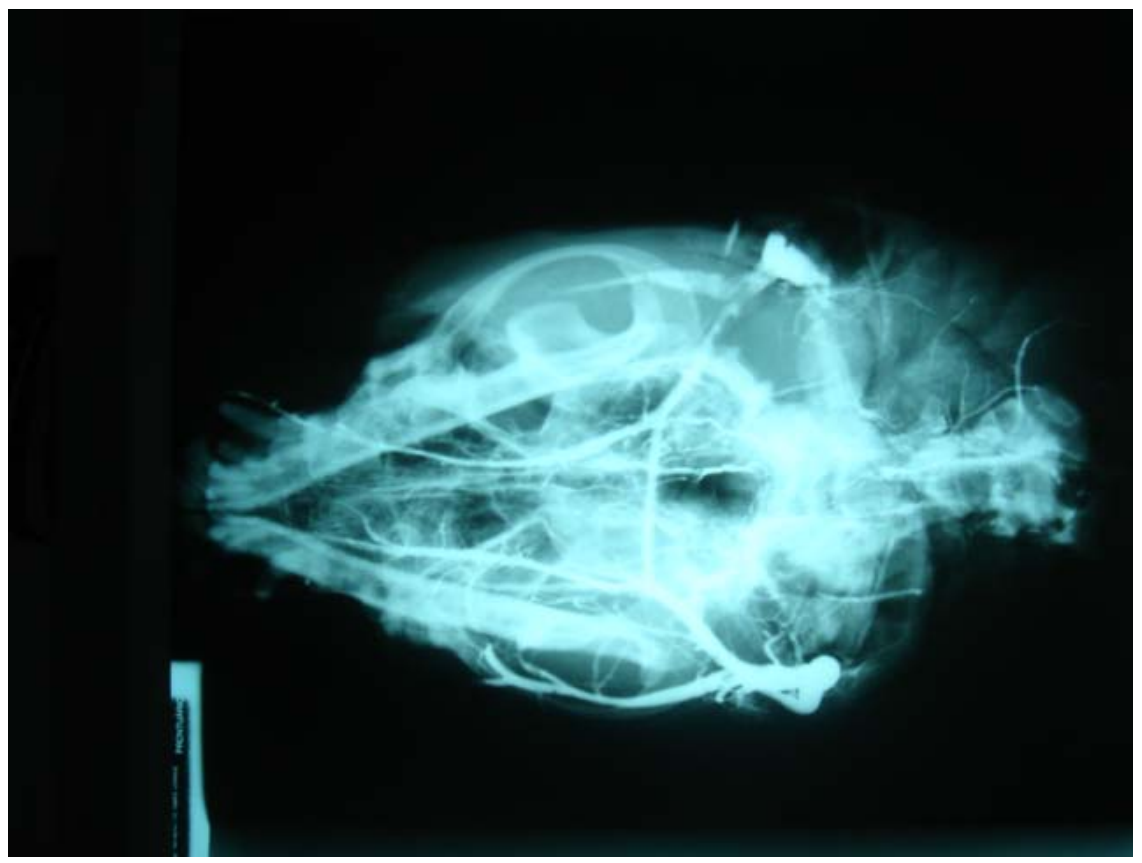

Figura 8 - Radiografia contrastada do crânio braquicefálico, incidência latero lateral esquerda (a) e dorso ventral (b) - São Paulo - 2006 


\section{APÊNDICE F}

a)

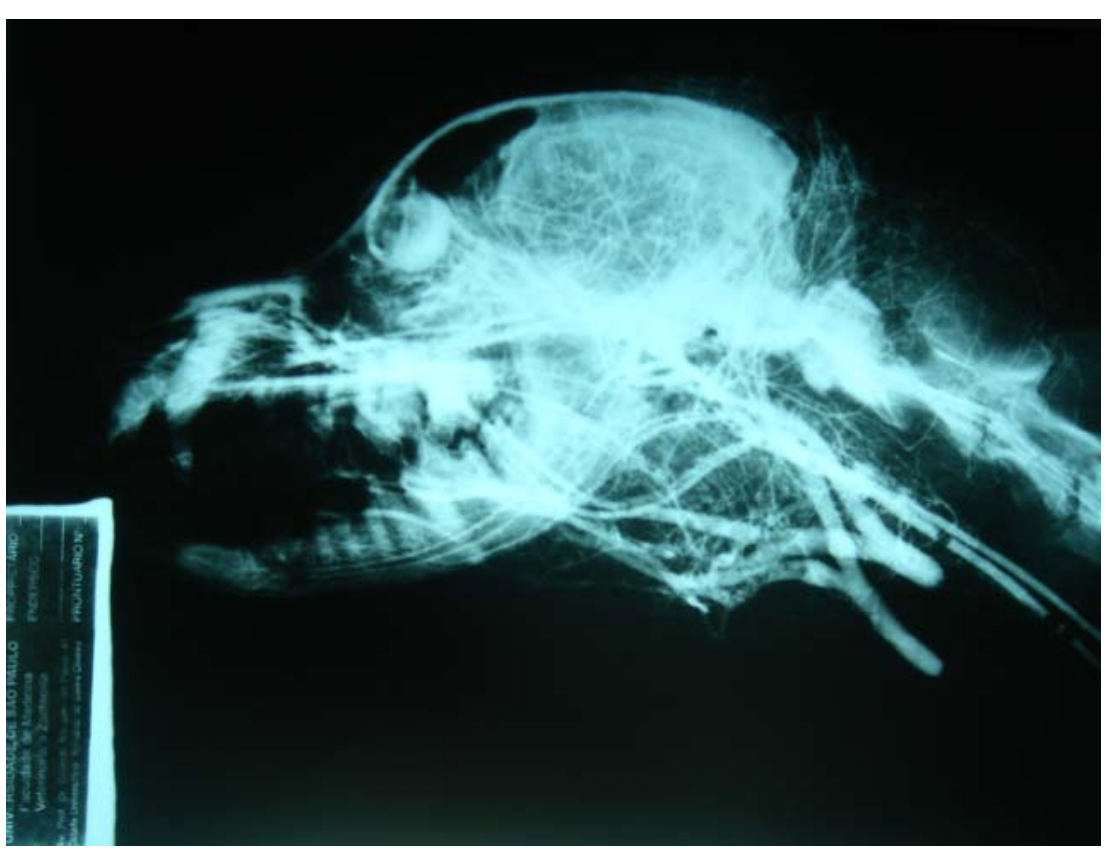

b)

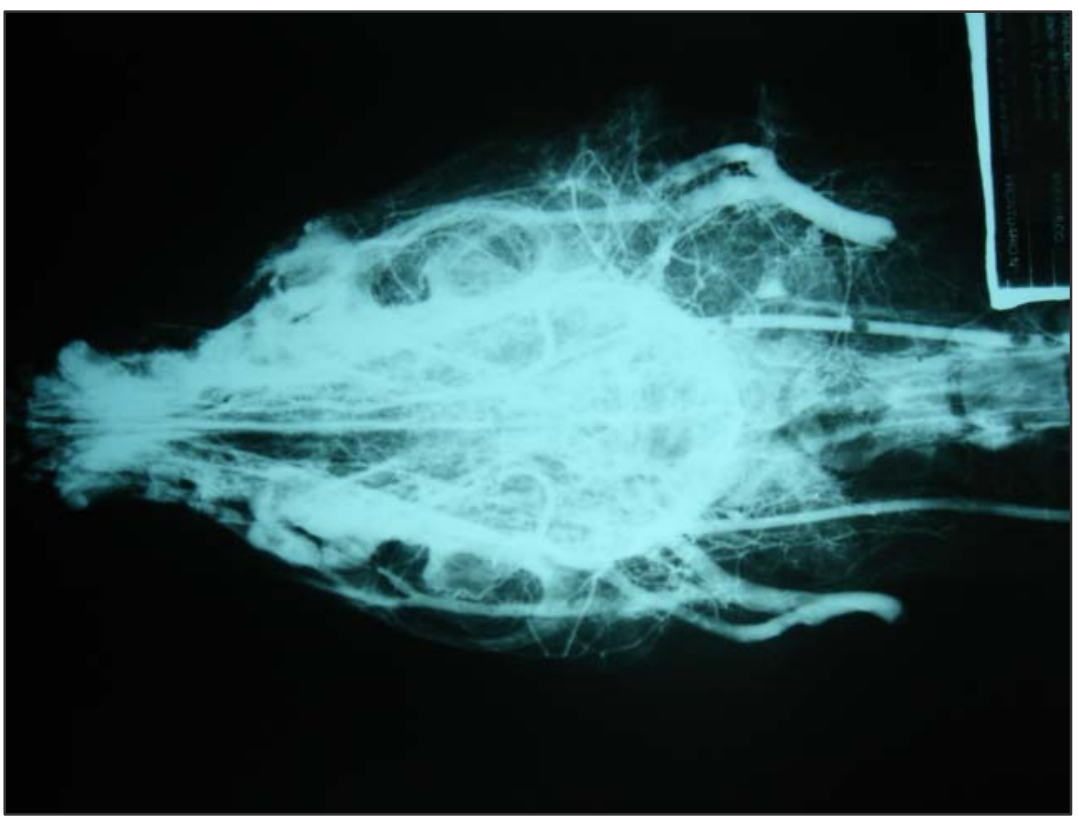

Figura 9 - Radiografia contrastada do crânio mesaticefálico, incidência latero lateral esquerda (a e dorso ventral (b) - São Paulo - 2006 


\section{APÊNDICE G}

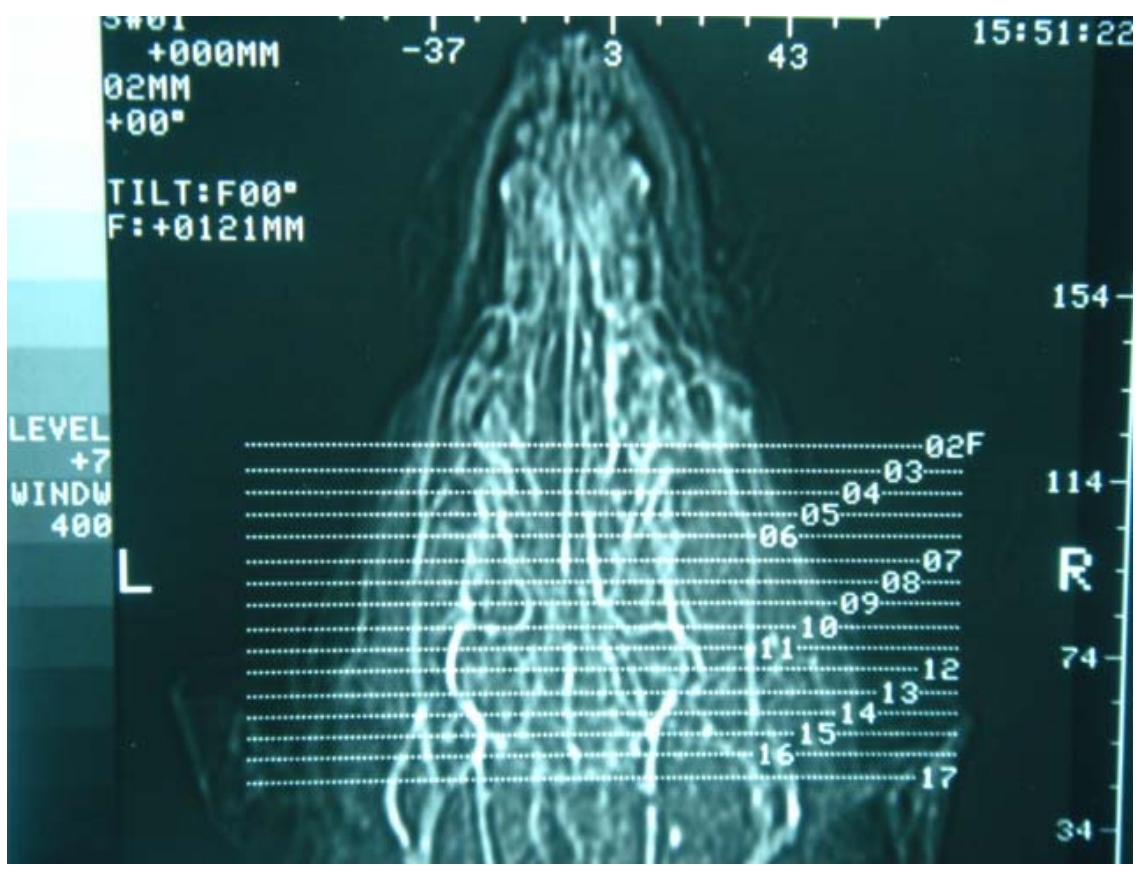

b)

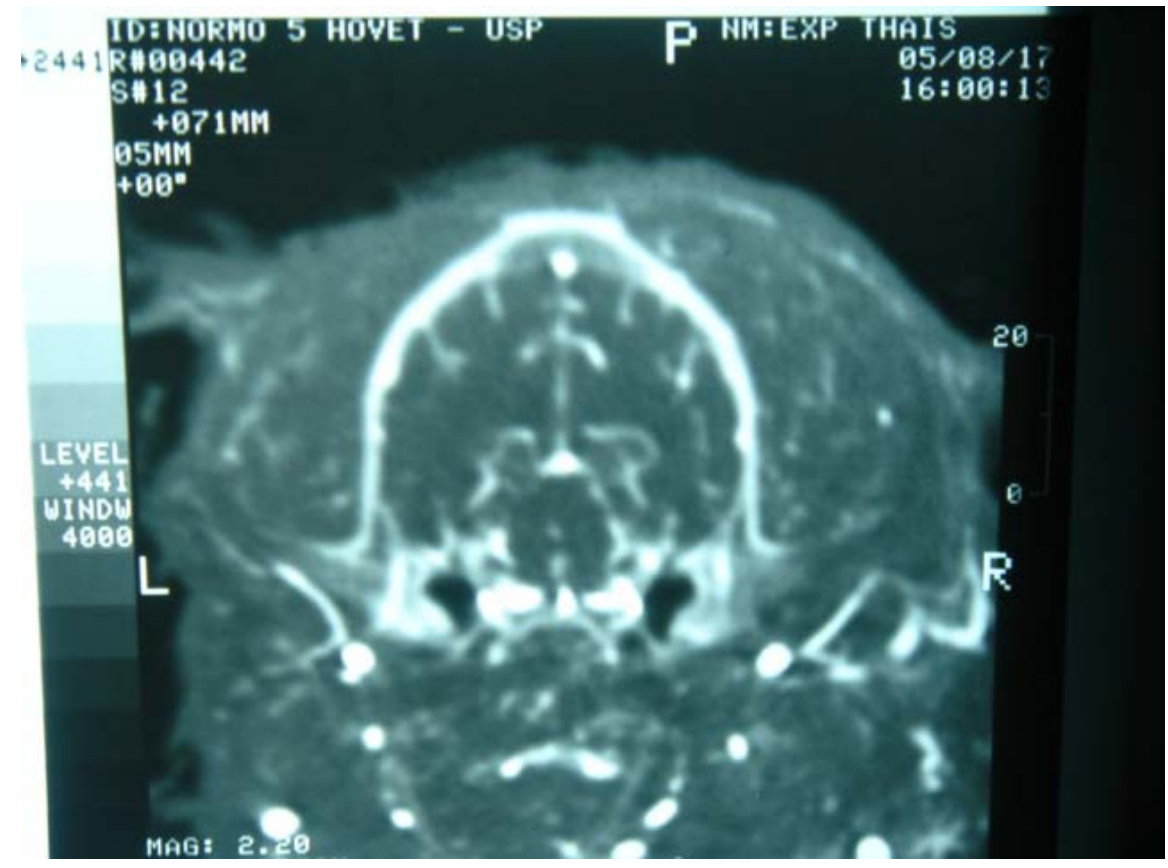

Figura 10 - Imagem da tomografia computadorizada do crânio mesaticefálico (M6), radiografia digital (a) e corte 12 (b) - São Paulo - 2006 
APÊNDICE H

a)

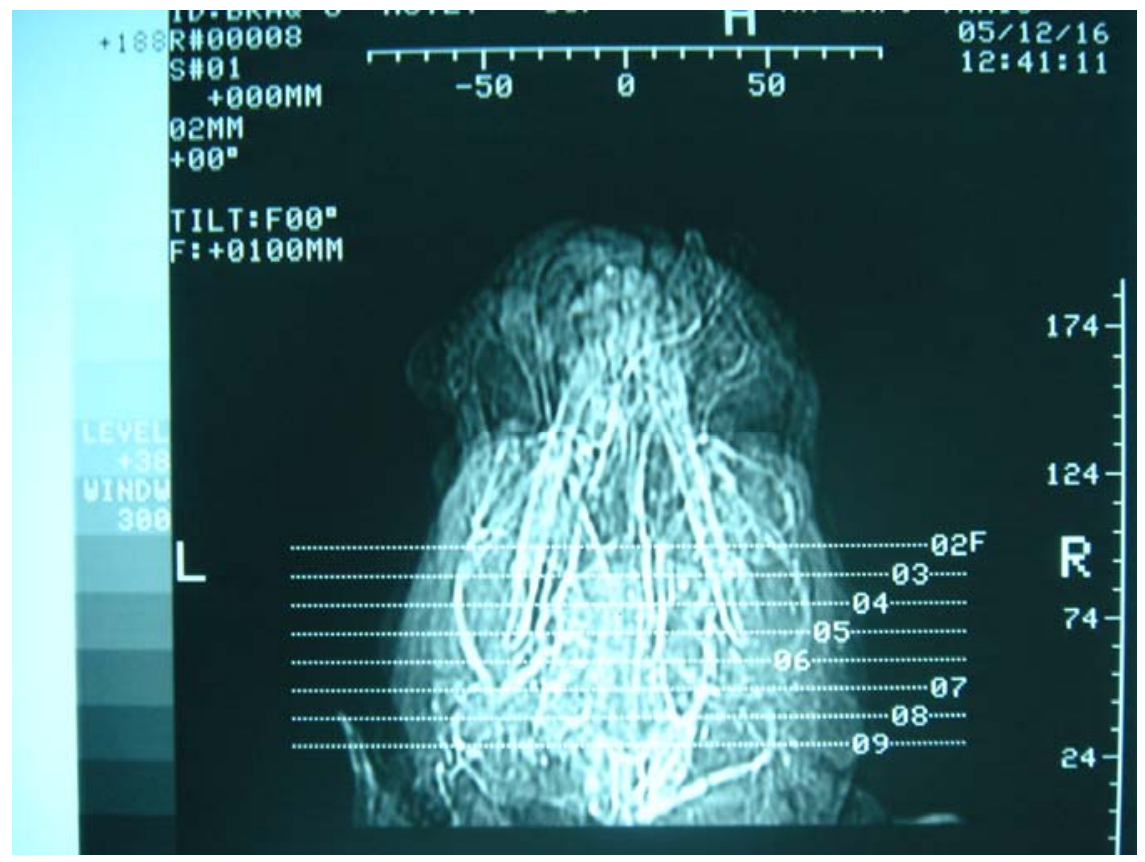

b)

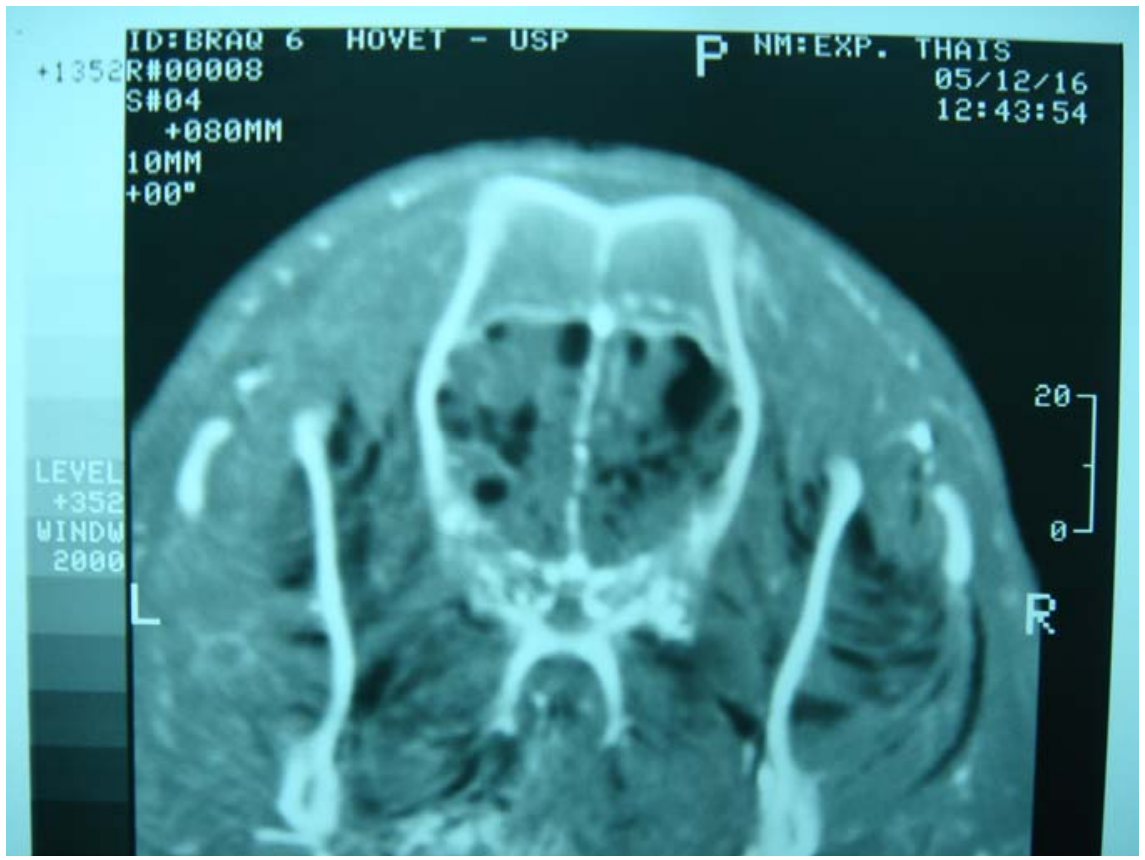

Figura 11 - Imagem da tomografia computadorizada do crânio braquicefálico (B6), radiografia digital (a) e corte 4 (b) - São Paulo - 2006 


\section{APÊNDICE I}

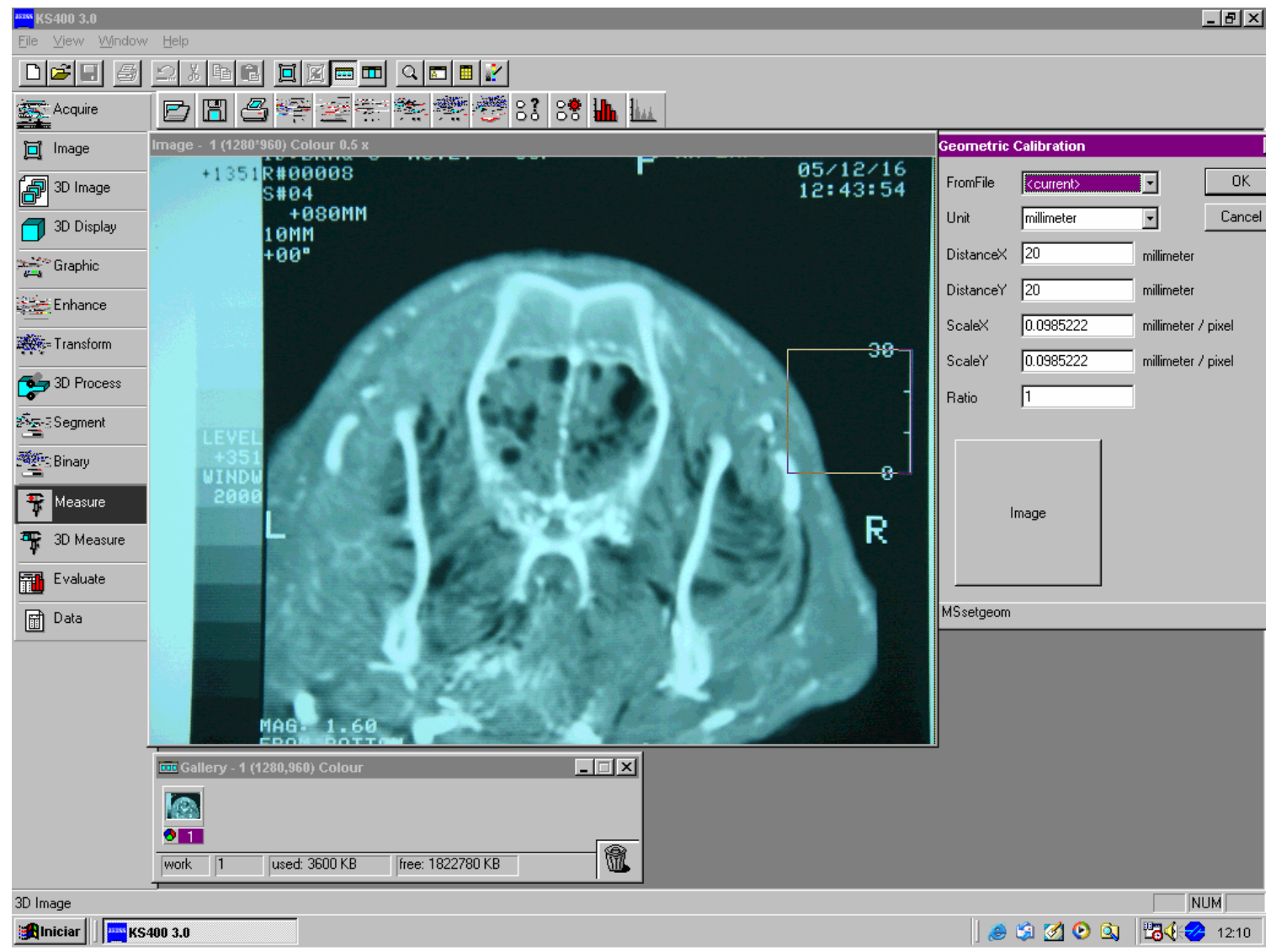

Figura 12 - Ferramenta Geometric calibration, janela do programa KS-400 3.0 São Paulo - 2006 


\section{APÊNDICE J}

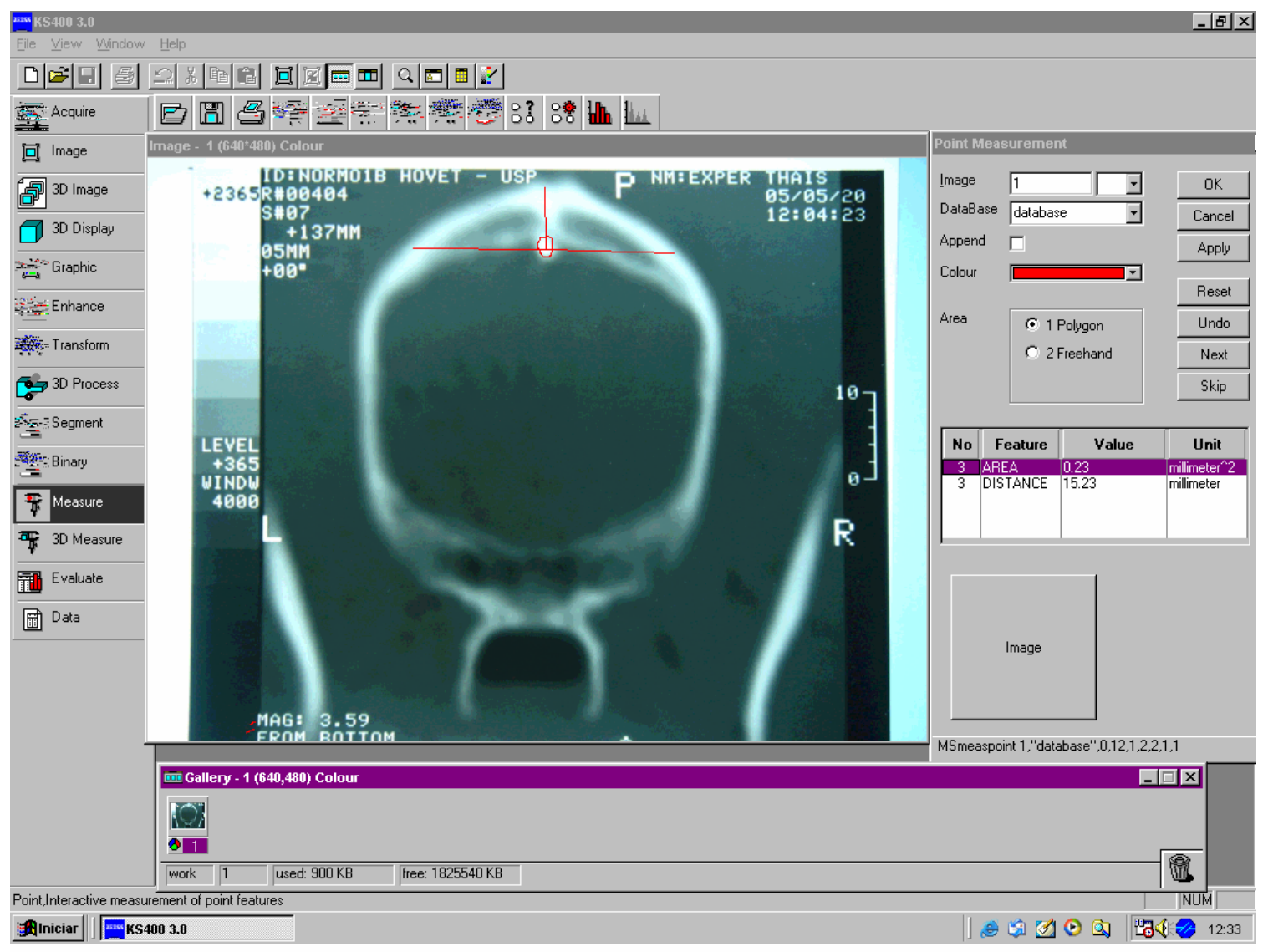

Figura 13 - Delimitação da área $\left(\mathrm{mm}^{2}\right)$, janela do programa KS-400 3.0 - São Paulo - 2006 


\section{APÊNDICE K}

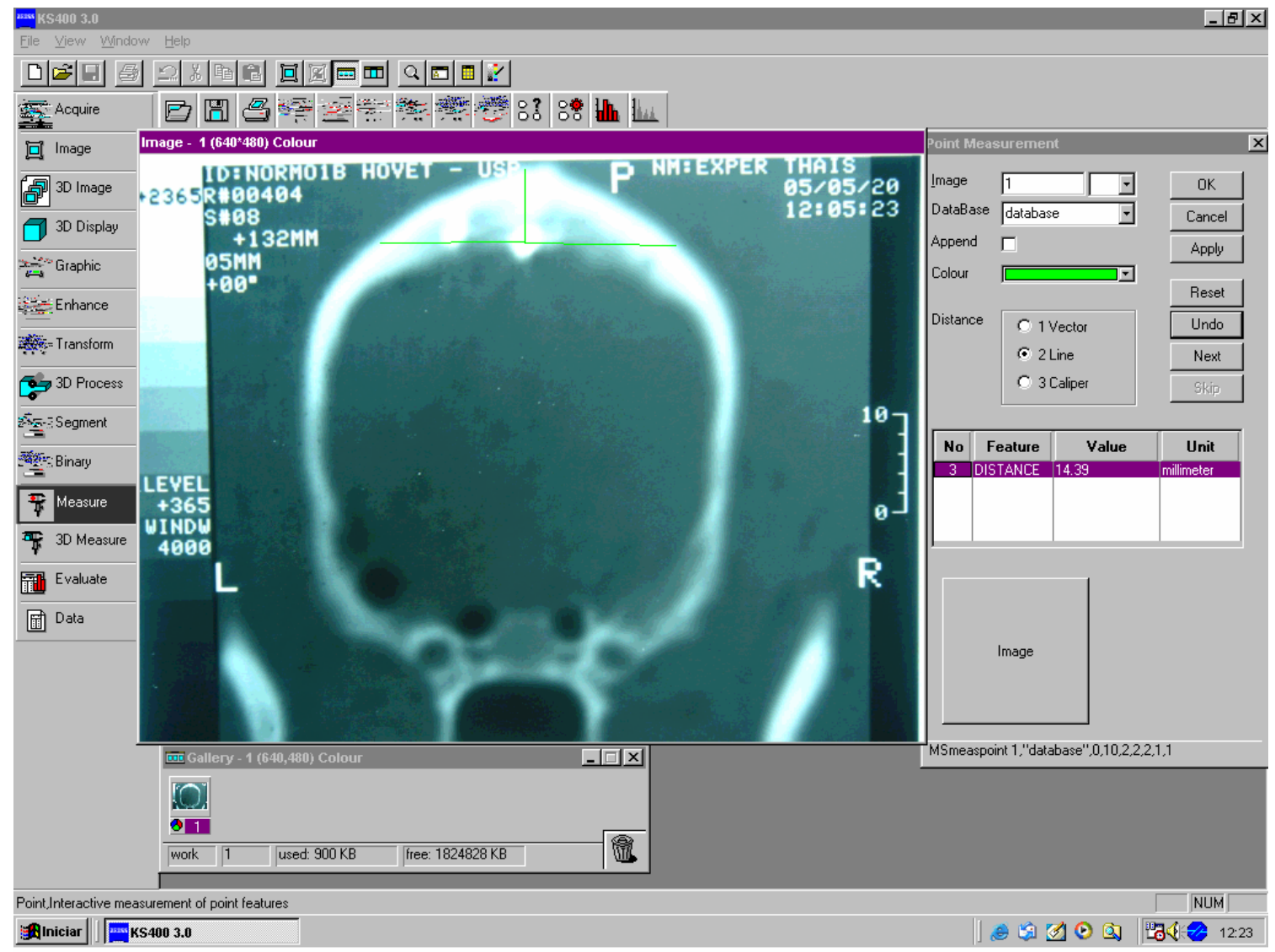

Figura 14 - Delimitação das medidas do ponto médio do SVSD ao ápice da calota craniana (D1) e às extremidades laterais da calota craniana (D2 e D3), em $\mathrm{mm}$, janela do programa KS 400 3.0 - São Paulo - 2006 


\section{APÊNDICE L}

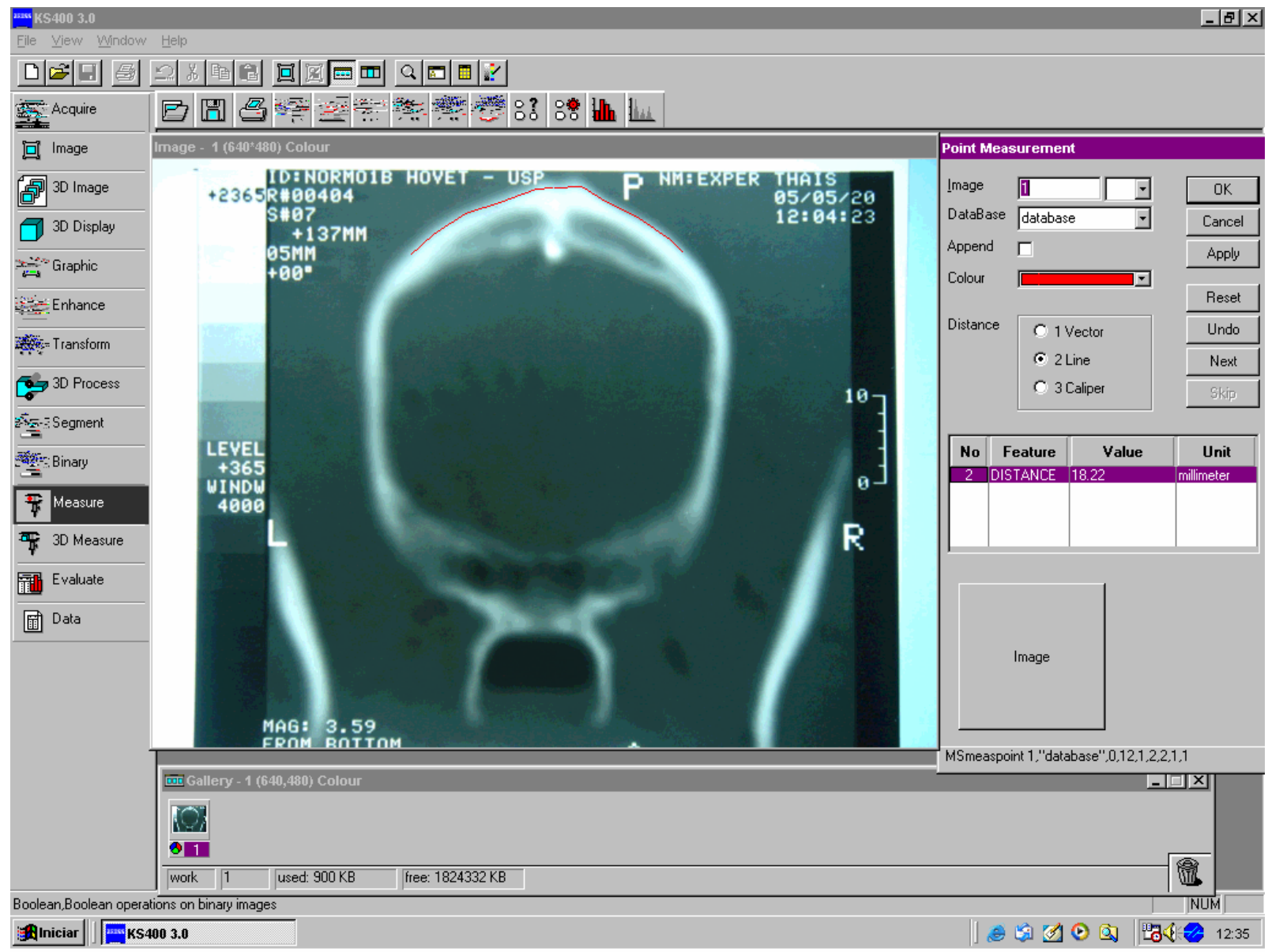

Figura 15 - Delimitação das medidas do contorno da calota craniana (D4 e D5) à intersecção com as medidas D2 e D3, em mm, janela do programa KS-400 3.0 - São Paulo 2006 
APÊNDICE M

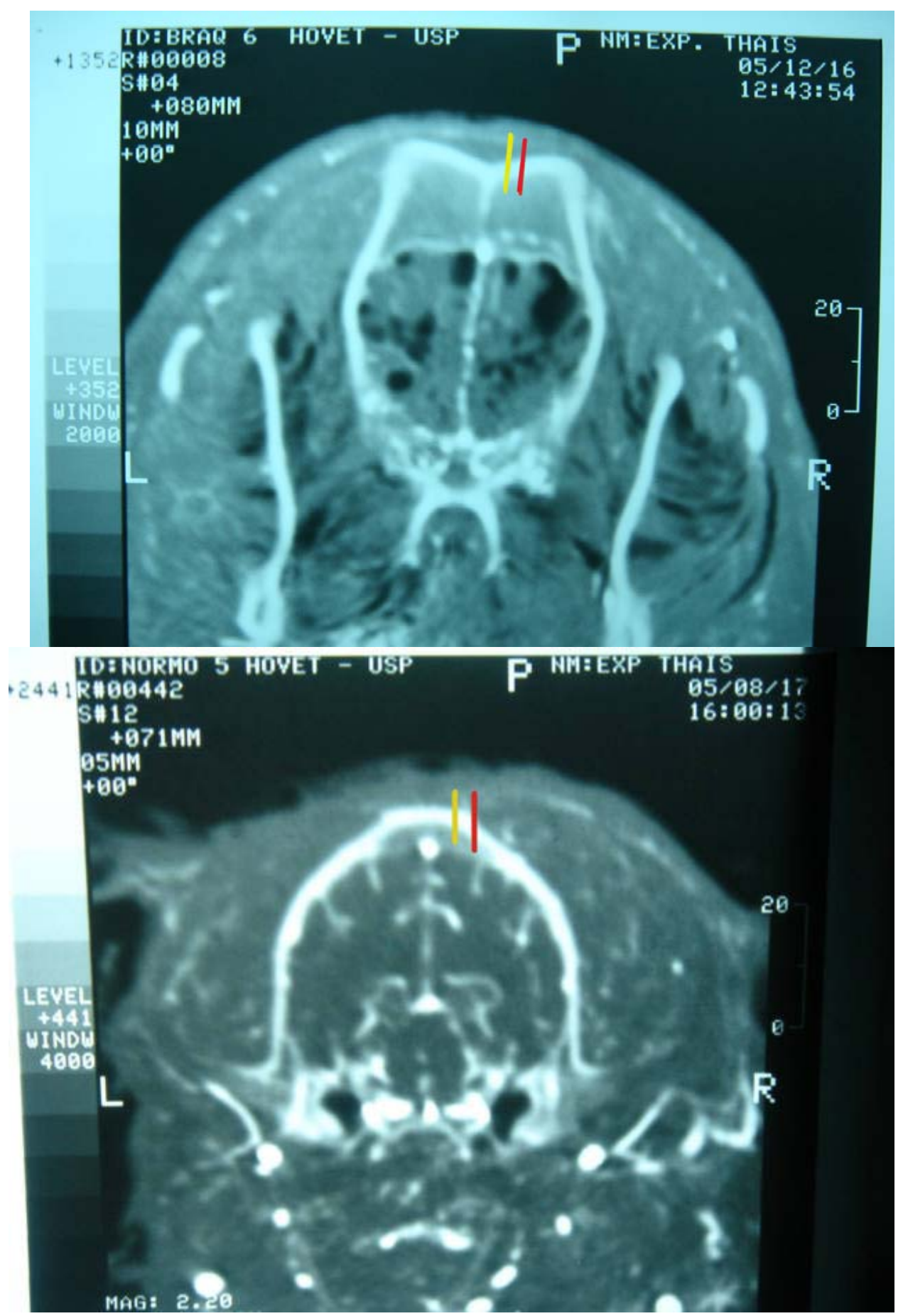

Figura 16 - Representação da margem de segurança para a incisão nos crânios braquicefálicos e mesaticefálicos; amarelo $=0,5 \mathrm{~cm}$; vermelho $=1,0 \mathrm{~cm}-$ São Paulo -2006 